\title{
ANALYSIS AND INTERPRETATION OF ICE-DEFORMED SEDIMENTS FROM HARRISON BAY, ALASKA
}

\author{
By \\ Steven A. Fischbein ${ }^{1}$
}

Open-File Report 87-262

This report was prepared under contract to the U.S. Geological Survey and has not been reviewed for conformity with USGS editorial standards and stratigraphic nomenclature. Opinions and conclusions expressed hercin do not necessarily represent those of the USGS.

${ }^{1}$ Geology Department, Califomia State University, Hayward, CA 


\section{CONTENT}

Page

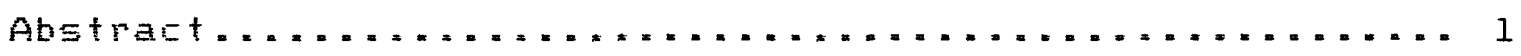

Asknoul edgements $\ldots \ldots \ldots \ldots \ldots \ldots \ldots \ldots \ldots \ldots \ldots \ldots \ldots \ldots \ldots$

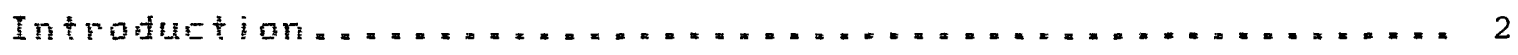

Lotation and Genlogit Setting.................. 2

Previous lork........................... 3

Purpose of Investigation $\ldots \ldots \ldots \ldots \ldots \ldots \ldots \ldots \ldots \ldots \ldots$

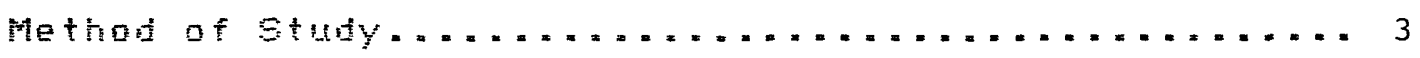

Core Exanination Foodure $\ldots \ldots \ldots \ldots \ldots \ldots \ldots \ldots \ldots \ldots$

General Geology

The coastal flain......................... 7

The Shelf.............................

Generai Core Descriptions and Environments of Deposition.. Il Distussion

Environments of Deposition...................

Ite Felated Deformation $\ldots=\ldots \ldots \ldots \ldots \ldots \ldots \ldots \ldots \ldots \ldots$

Ine Gediment Interaction...................... 41

Glatial Labe Agassiz:

An Example of Freserved I Ge Gouges . . . . . . . . . . . . 48

Late Fieistocene Lasustrine Sediments of the ontario

Easin: Eanada Ar Alternative Interpretation....... 51

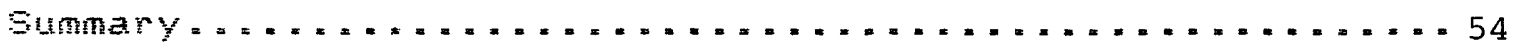

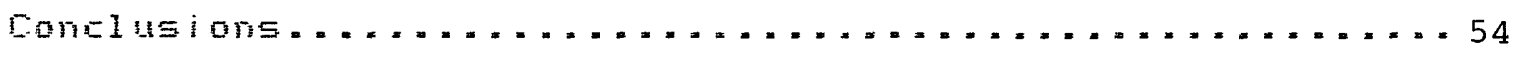

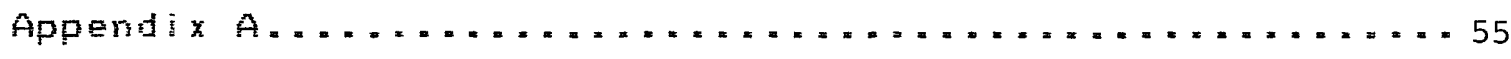

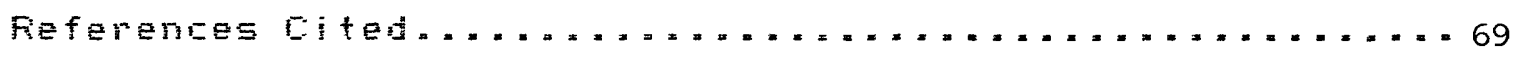




\section{FIGURES}

Page

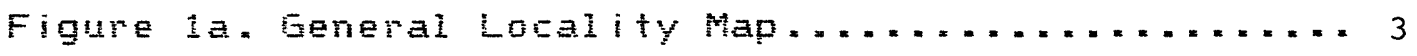

Figure 1b. Detaled Locality Map............... 4

Figure 2 . Side Soan Soner Image $\ldots \ldots \ldots \ldots \ldots \ldots \ldots \ldots$

Fiqure 3a. Uniboom Seismic profile............. 9

Figure 3t. 7 Khz end 200 khz Selsmit Profile........ 10

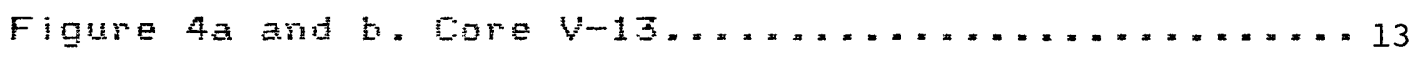

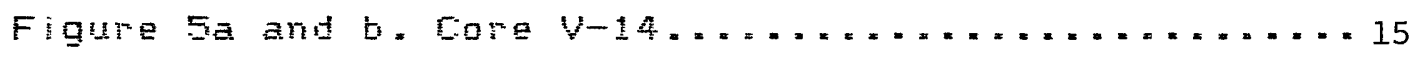

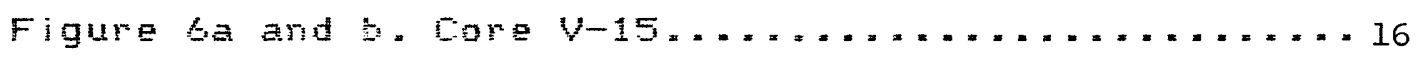

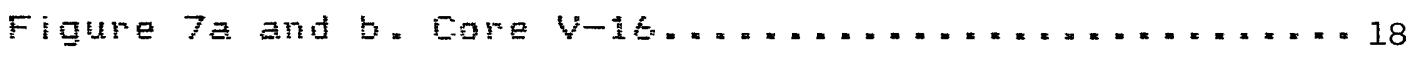

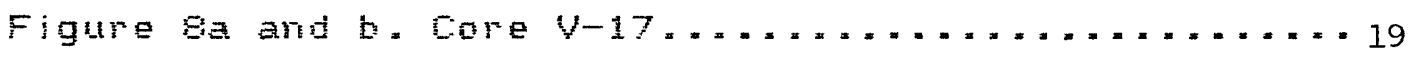

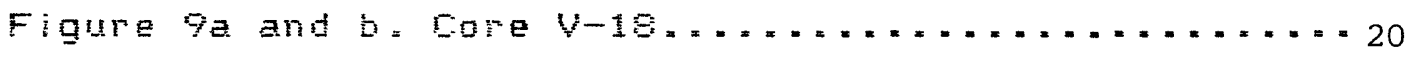

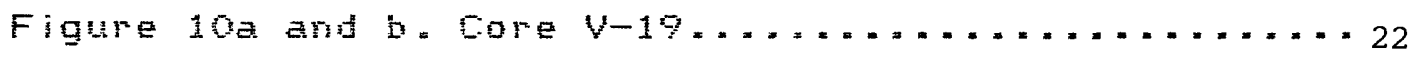

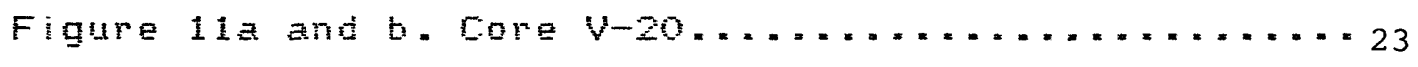

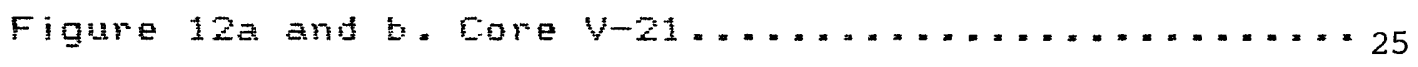

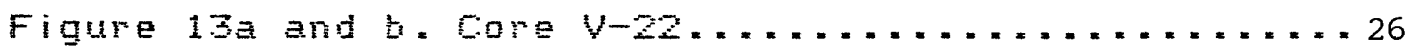

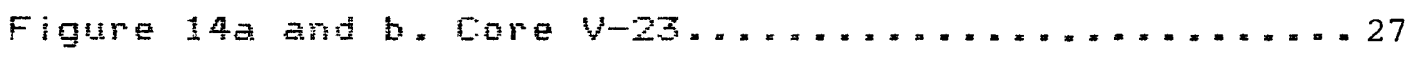

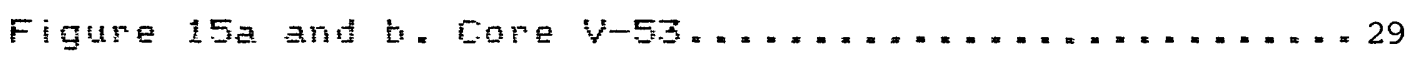

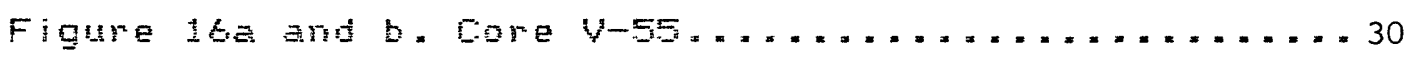

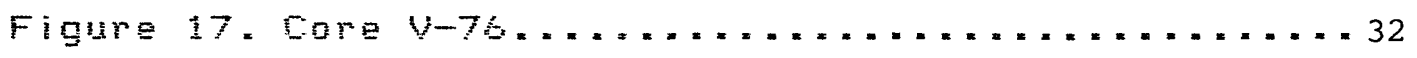

Figure 18a. Comparison Cores from Guadalupe Delta....35

Figure 19t. Comparison Cores from Guadalupe Delta.... 36

Figure 17. Shelf Profile and Facies Assogiations..... 37

Figure $20 a=b=t$. IEe Gouge Deformation Mode1 ........ 39

Figure 21. Schemati: Drawing of Ire Gouge Frocess... 42 
Figure 22 . Hypothetical crose-gertion. . . . . . . . . . 43

Figure 23 . Sketin of Cone $V-16 \ldots=\ldots \ldots \ldots \ldots \ldots \ldots=\ldots 44$

Figure 24. North Sea Ice-Deformed Sediments . . . . . . . 45

Figure 25 . Ine Gouge Intensity Hap. . . . . . . . . . . 46

Figure zb. Ire Gouged Sediments From Lake Agassiz.... 50

Figure 27 . Ice Gouged Sediments From Lake Ontario... 52 


\section{AESTRACT}

The surficial sediments present on the continental shelf off the north coast of Alaska in the vicinity of Harrison Bay consist dominantly of fine grained sand, silt, and mud that were deposited during Holocene time. Depositional environments in Harrison Bay range from outer shelf to prodelta and delta front.

Ice sediment interaction has overprinted structural deformation on many of the sediments present in Harrison Bay, and has in some cases obliterated the original lithologic continuity of the sediments. Ice related Jeformation ranges from simple loading features to more complex folded and faulted structures. A hypothetical model has been proposed which relates the type of deformational features found in recent sediments from an ice impacted area to the process of ice gouging.

The deformational structures observed in the sediments from Harrison Bay were compared to deformational features found in sediments from ancient environments that are known to have had floating ice present. The results indicate that structures found in the modern environment bear a remarkable similarity to structures found in the ancient environments. and that the structures found in the ancient environments are bel ieved to have been caused by the process of ice gouging.

\section{ACKNOWLEDGEMENTS}

I would like to thank Dr. Detlef Warnke for offering me the chance to work on this project and managing all the administrative details associated with it. I would also like to thank Dr. Peter Barnes and Dr. Erk Feimnitz of the United States Geological Survey for allocating the

funding for this project, eritically reviewing the manuscript, and allowing me to analyze their field data. I also offer thanks to Mr. Mike Zani for helping me understand the math behind the physics of partially buoyant objects.

I offer my most sincere thanks and gratitude to my parents, Irwin and Sarah Fischbein. whose love and undying belief in my ability has always motivated me to pursue ever higher education. and to my wife fiobin. who has supported me both financially and emotionally through this degree and who has constantly encouraged me to chase my second greatest love only to her, geology. Finally I would like to dedicate this work in memorium to Dr. Geoffrey Davidson Woodard whose lust for the science of geology was contagious and inspirational, and who, in the face of terminal cancer, threw down the gauntlet to the powers that be and continued his field 
work to the end.

\section{INTRODUNT ION}

Depositional processes on high latitude continental shelves are obscured by the presence of pack ice for at least three-fourths of every year. The role which the ice plays in influencing the sediment deposited on the continental shelf is not yet fully understood, al though many ideas have been formulated. One ice-sediment interactive process known to occur is that of ice gouging or ice ploughing. The internal deformation of sediments associated with this process is 1 ittle known and is the main topic of investigation in this report.

\section{LOCATION AND GEOLOGIC SETTING}

The study area is located off the northern Alaska coast between $150^{\circ} 00^{\prime \prime}$ and $152^{\prime}$ o0" west long. and $70^{\circ} 30^{\prime \prime}$ and $71^{\circ}$ oo" north 1 at. in the Eeaufort Sea of the Colville River delta in Harrison Bay (Figure la and b). Water depths in the study area range from approximately two meters near the Colville delta, to 20 meters in the northern part.

The coastline in the study area is being eroded at the rate of approximately $2.5 \mathrm{~m} / y$, except for the eastern, active part of the colville Delta. which is accreting (Reimnitz et al.. in press). This erosion creates coastal bluffs that are typically 2 to $3 \mathrm{~m} \mathrm{high}$ but may reach a height of 6 meters (Feimnitz and Barnes. 1974; Reimnitz et al:s in press). The line of bluffs is broken by the impingement of several river systems whose general morphological character consists of low prograding deltaic mudflats at the river mouths (Reimnitz and Barnes, 1974). The coastal plain is an area of 1 ow toroad relief capped by tundra vegetation. This coastal plain is underlain by Tertiary to Pleistocene and Holocene moraines, glaciomarine deposits, erratic-bearing gravel, eolian sand, gravel, sand and silt (Black, 1964; Fayre et al., 1951; Carter. 1983b).

The continental shelf in the area is generally flat and remains shallow for a considerable distance from shore (Reimnitz and Barnes, 1974). A detailed examination of shelf topography shous it to be extremely rough on a small scale. The small sicale morphological character of the shelf is dominated by the presence of 1 ong 1 inear criss-crossing grooves produced by the grounding of ice keels below pressure ridges (Barnes et al., 1984). The grooves are characterized by troughs and ridges that are typically $1 \mathrm{~m}$ deep and $7 \mathrm{~m}$ wide (Barnes et al.: 1994), although some may reach $10 \mathrm{~m}$ deep and $30 \mathrm{~m}$ uide (Barnes and Rearic, 1985) (Figure 2 ).

The surface sediments on the shelf are dominantly 


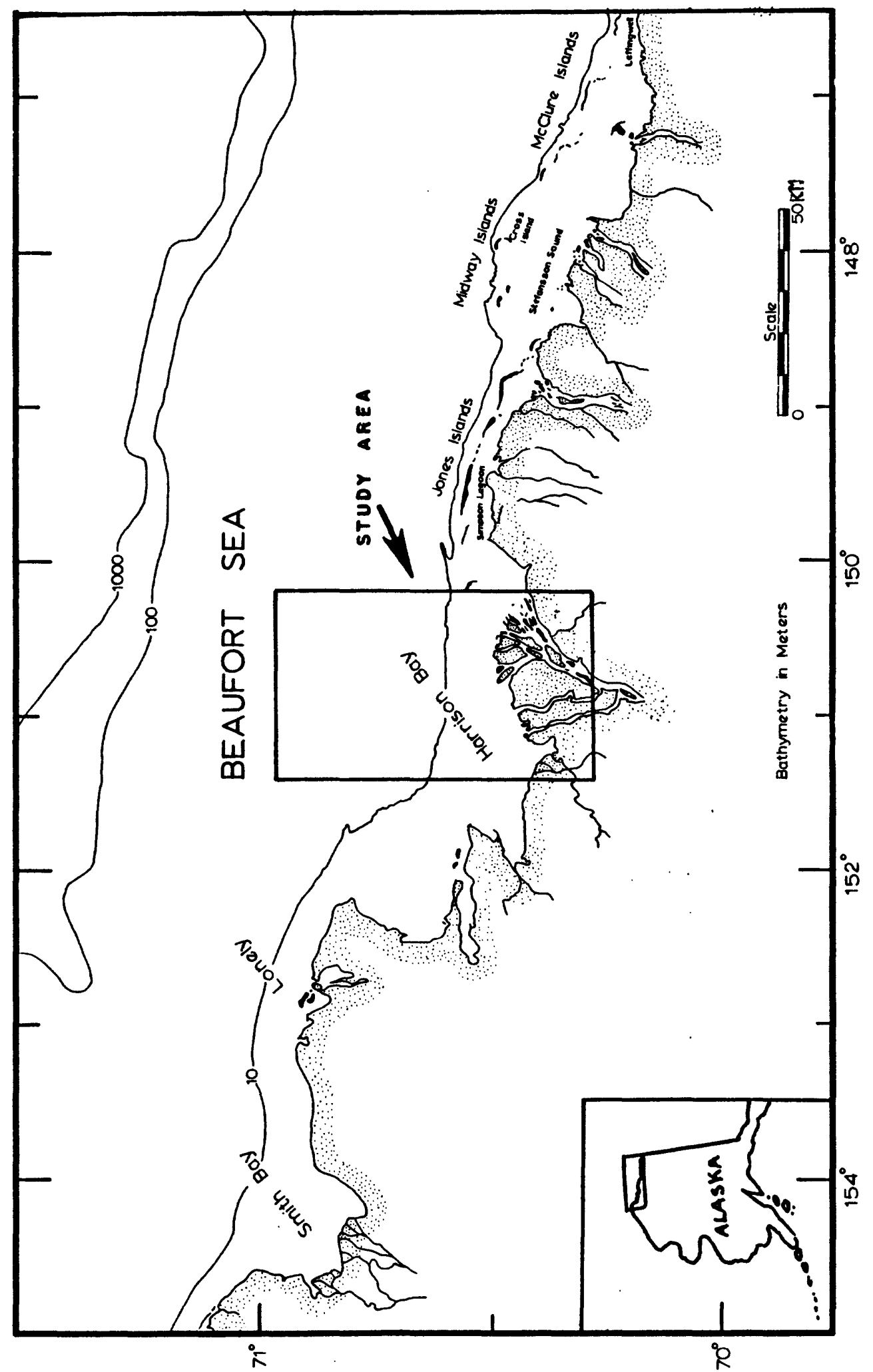

Figure 1a. Locality map showing position of study area in relation to the north Alaskan coast. 


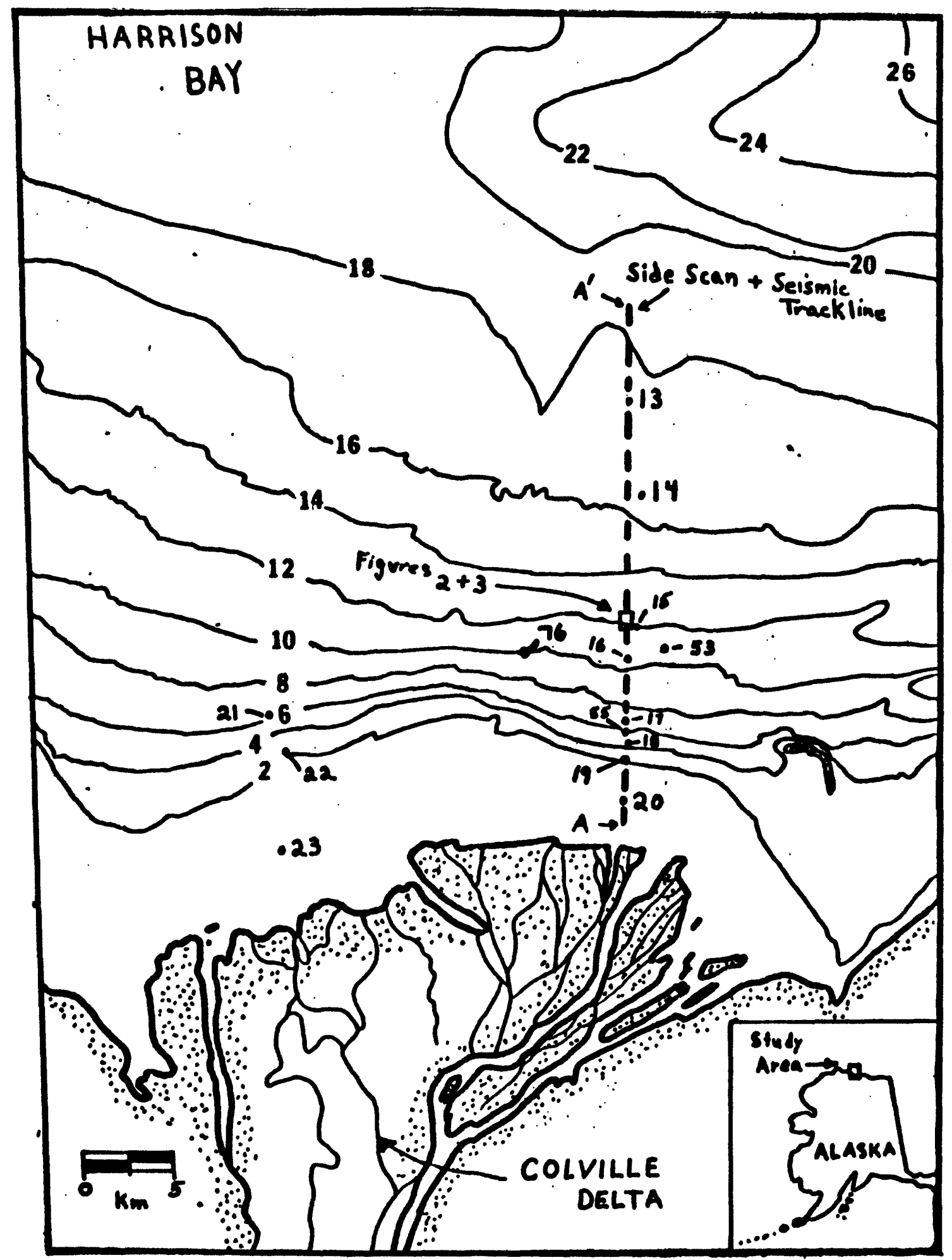

Figure 1b. Detailed locality map of Harrison Bay showing bathymetry ( $2 \mathrm{~m}$ interval), core 1 ocalities, ships track 1 ine, and location of side scan image and seismic profile in figure 2 and 3 . Vessel track 1 ine is labeled $A-A$ ' and corresponds to shelf profile in figure 19. 


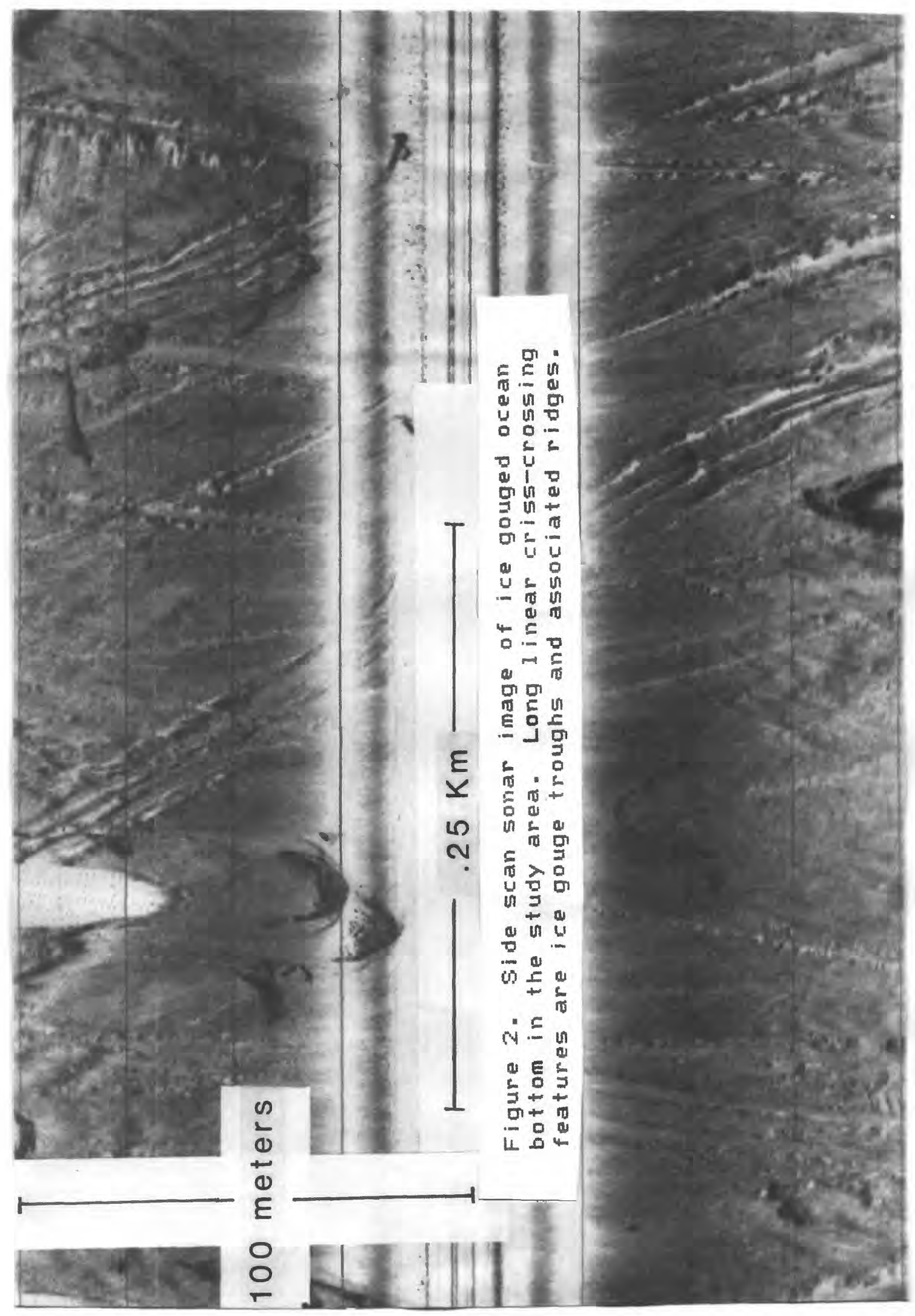


fine mud, clay and sand, but gravel and occasional boulders are encountered (Barnes and Feimnitz; 1974). The Colville Fiver and eroding coastal bluffs are introducing large amounts of fibrous organic matter to the seas and some is found incorporated in recent sediments (Barres et al = 1979).

\section{PFEVIOUS WORK}

One of the earliest investigations on the process of ice gouging was done by Tarr (1897) who observed and documented the effects of grounded ice on sediments. Emery (1949) and Carsola (1954) performed early studies of the topography and sediments in the Eeaufort Sea: while Fex (1955) described sea-floor microrel ief caused by grounded sea ice in the northern Chukchi Sea. More recent work defining characteristics and rates of ice gouging was done by Kovacs (1972). Pelletier and Shearer (1972): Barnes and Fieimnitz (1972, 1973, 1974), Feimnitz and Barnes $(1972,1973,1974)$, Barnes et al . (1973, $1979,1985)$. Fieimnitz et al. (1972, 1973, 1974), and Kempena (1993) analyzed the stratigraphy of an individual ice gouge. Naidu (1974), and Naidu et al. (1971, 1972, 1974) analyzed clay mineralogy,

sedimentation, and sediment geochemistry of the Beaufort Sea. Yorath et al. (1970) interpreted seismic profiles and sediments of the Beaufort Sea.

PURPDSE OF INVESTIGATION

The major emphasis of this report is to:

1) Ascertain what sedimentary structures, textures, and 1 ithologies characterize deposition in an arctic shelf environment that is influenced by a large fluvial system.

2) Delineate the type of deformational structures that may be overprinted on the sediments in that environment through ice-sediment interaction.

3) Describe in detail cores collected in the Harrison Bay area of the Beaufort Sea during 1976 and 1977 by the United States Geological Survey branch of Pacific Marine beology.

The study area was chosen because the north-south transect of available cores might provide a cross-section through surficial sediments on the shelf perpendicular to the coastlines from a shallow deltaic environment to the midshelf at $20 \mathrm{~m}$. where ice gouging may strongly influence deposition.

\section{METHOD OF STUDY}

The cores were gathered using a vibratory coring device lowered from the research vessel to the sea floor. A pair of electrically driven. counter rotating. eccentric weights in the core head rapidly hammers 
against an anvil driving the core barrel into the sediment (Earnes et al $=$. 1979). After retrieval c cores were capped with paraffin or plaster of Paris to seal them and were subsequently shipped to Menlo Park, California for laboratory processing (Barnes et al.s 1979 ).

Cores obtained during the $1976-1977$ field seasons were sliced longitudinally and resin peels and $x-r a y$ radiographs were made from each core. A visual examination of cores, peels and radiographs has been undertaken in this study, as outlined below.

\section{CORE EXAMINATION FROCEDURE}

Each of the 15 available cores were examined together with their corresponding peels and radiographs. Each radiograph had a corresponding black and white contact print made from it for ease in description. The contact prints were attached to boards and 1 ithologic as well as structural information obtained from the cores and peels was uritten directly onto the margin of each appropriate board. In this way, the prints could then be laid out together with all the corresponding information. The prints were then overlain with clear acetate, and all sedimentary structures were traced in detail to better ascertain their type and possible origin. This method provided a weal th of information and proved best for this study.

\section{GENERAL GEOLOGY}

THE COASTAL FLAIN

The subaerial coastal plain in the vicinity of Harrison Bay and the Colville River consists of a broad plain of low relief mantled by Quaternary and Recent sediments that rest unconformably on Mesozoic sedimentary rocks (Walker, 1976). This area received minimal glaciation during Quaternary time (approximately 10\%) (Walker, 1976, Dinter, 1982). The glacial and glaciofluvial deposits which resulted contribute to the sediment load of the Colville River and its tributaries at present (Walker, 1976).

The sediments that mantle the coastal plain consist of late Cenozoic marine, lacustrines alluvial, glacial, and eolian deposits (Carters 1983b), referred to as the Gubik Formation (Carter. 1986) and the glaciomarine deposits are known as the Flaxman Formation (Carter, 1986).

The most prominent geologic structure in the area is the Barrow Arch, a buried ridge of Early Paleozoir rocks deformed during the Ellesmerian orogeny. The 
structure is overlain by Late Paleozoic and Mesozoic rocks that arch over the crest of the $r i d g e$, and are truncated by an unconformity. The unconformity is capped by Crefaceous shale (Stearn et al . 1979).

The coastal plain in the study area is geomorphically dominated by the presence of the Colville River Delta. The Colville fiver has created a delta that has an areal exposure of approximately $6005 \mathrm{~g} . \mathrm{km}$. The del ta is approximately $40 \mathrm{~km}$ from its apex to the ocean. and is approximately $45 \mathrm{~km}$ wide along its front (Walker, 1973). The Colville River is the largest river in arctic Alaska, and has a drainage basin dimension of $60,000 \mathrm{sq}=\mathrm{km}$ (Walker, 1976).

\section{THE SHELF}

The continental shel of the north coast of Alaska was subaerially exposed to approximately the $100 \mathrm{~m}$ isobath as a result of a eustatic sea level minimum, caused by late Wisconsin qlaciation (Dinter. 1982; Dillon and oldale, 1978). The glacial maximum and sealevel minimum occurred approximately 17 , 000 years ago (Dinter, 1982; Dillon and oldale, 1978). The shelf at that time formed an unconformable surface which has been del ineated seismically and assigned a tentative age of Fileistacene, based on the timing of the retreat of the last glaciation (Craig and Thrasher. 1982; Dinter: 1982). In the study area. Holocene sediments that overlie the unconformity are believed to reach a thickness of no greater than $5 m$ (Reimnitz and Barnes. 1974).

The Quaternary sediments have been delineated seismically into three generalized units by Craig and Thrasher (1982). The surficial Holocene unit is 0 to approximately $5 \mathrm{~m}$ thick and consists of an acoustically transparent layer displaying vagues continuous bedding subparallel to the seafloor. The underlying Holocene-Pleistocene boundary consists of a strong continuous reflector cut locally by shall ow channels and low terraces (Figure $3 a$ and b). The Fleistocene unit has been broken into two units ( $A$ and $B$ respectively) based on acoustic character, only unit $A$ can be recognized in the study area.

The upper boundary of unit A consists seismically of a diffuse to sharp reflecting surface that is commonly characterized by a very jagged or "jumpy" appearance (Figure $3 a$ and $b$ ). The surface of unit $A$ is bel ieved to correlate in appearance to the morphological features of the present day coastal plain. including $V$-shaped stream channels; thaw lakes; beach ridges, and thermokarst topography (Craig and Thrasher, 1982). 


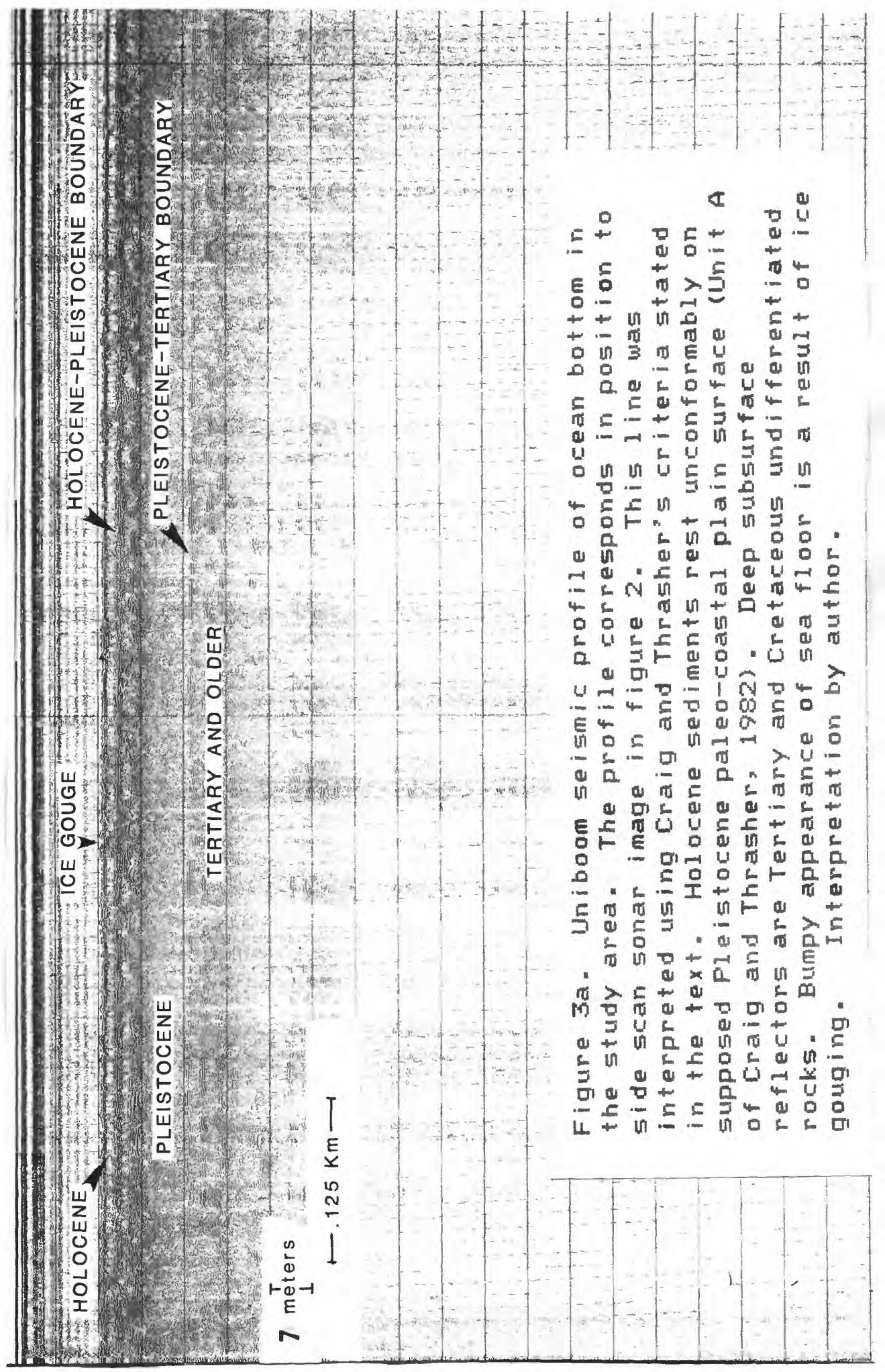




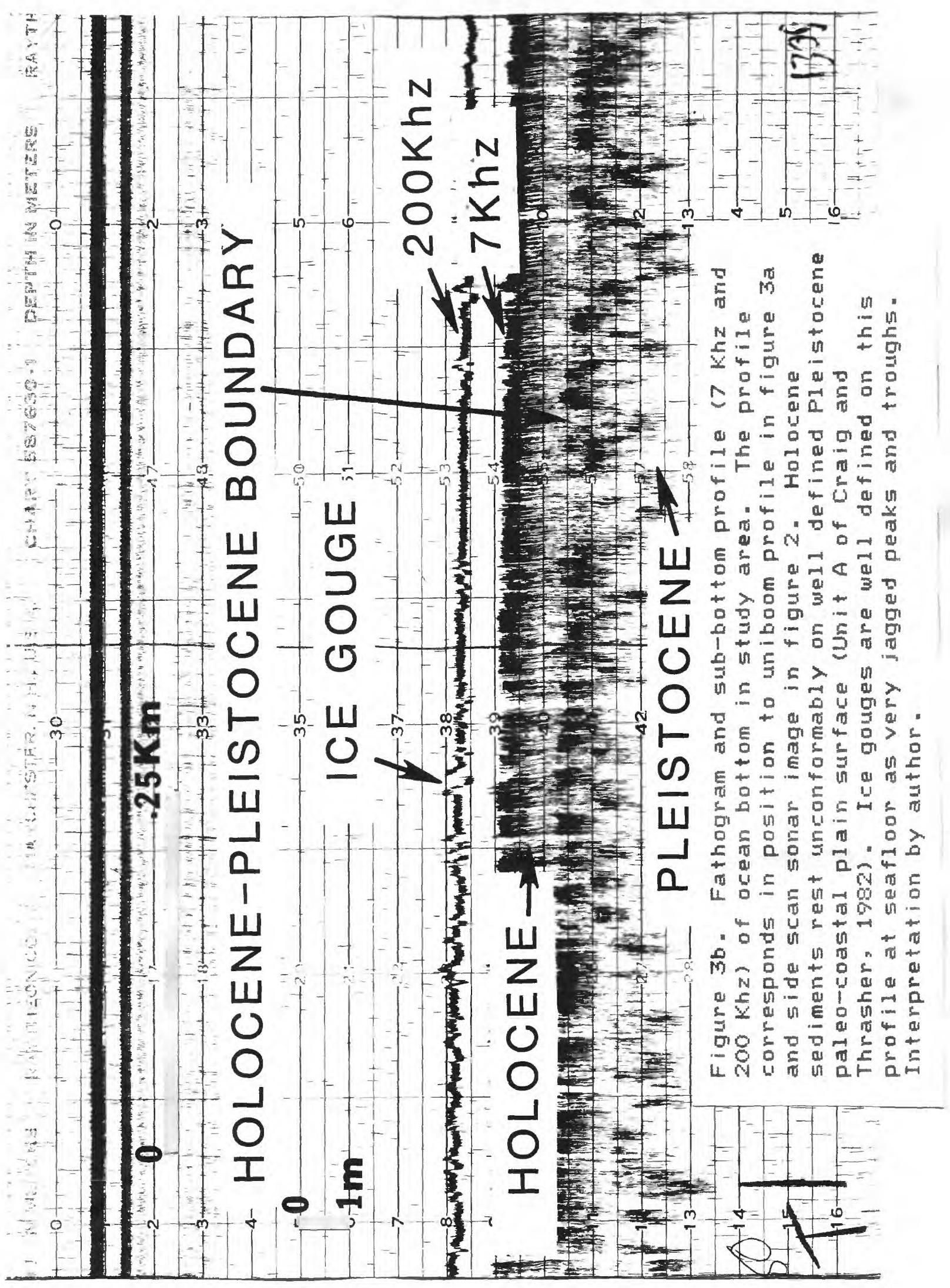


Unit $B$ seismically consists of a sharp. strongly reflective surface of uniformly low relief that is believed to represent a marine deposit contemporaneous with unit $A$. Several morphological features indicative of a marine environment such as sedimentary bedforms. beaches, and offshore bars have been interpreted (Craig and Thrasher 1982 ). The contact between unit $A$ and unit B represents a facies change and generally follows the $20 m$ isobath. The almost vertical contact is very abrupt and is interpreted as a shoreline bluff several meters high. The morphological expression of the shoreline is not reflected at the seafloor cCraig and Thrasher: 1782). It should be noted that the inferred shoreline corresponds in position to the inner edge of the stamukhi zone of Reimnitz et al. (1978), an area of intense ice reworking by pressure-ridge keels. Unit $A$ and unit $B$ are approximately 10 to $12 \mathrm{~m}$ thick in the study area (Barnes, 1987, personal communication), and are believed to correspond to the Gubic Formation onshore (Craig and Thrasher, 1982).

Units $A$ and $B$ unconformably overl ie Late Cretaceous and Tertiary undifferentiated sedimentary roiks knou as "Colville Group and younger rocks" and consist of shale and laterally discontinuous sand bodies characteristic of a regressive marine sequence (Craig and Thrasher 1982 ).

\section{GENERAL CORE DESCRIPTIDNS AND ENVIRONMENTS OF}

\section{DEPOSITION}

In this section, each core is first described and then assigned a depositional environment based on lithologic, textural, and structural criteria. Photographs of peels and radiographs are used to illustrate and support each case. Detailed descriptions of individual cores can be found in Appendix $A$.

The cores studied in this report display characteristics of several distinct depositional enviromments when compared to sediments described by Tucker (1981), Feineck and Singh (1780), and Reading (1786) from lower latitude shelves. The depositional environments are on occasion overprinted by deformation caused by ice-sediment interaction and by coring.

The general sedimentological characteristics described for a lower of shore depositional environment are laminated to highly bioturbated muds, derived from suspension settling. interbedded with parallel laminated, occasionally ripple laminated, fine grained sands, derived from storm-generated currents (Tucker, 1981; Reineck and Singh. 1980 F Feading, 1986). This environment is usually found in water depths greater than $10 \mathrm{~m}$ (Tucker, 1781; Reineck and Singh, 1980; 
Reading: 1986 ).

Fieineck and Singh (1980) and Feading (1986)

describe an upper offshore environment in water depths of 2 to $10 \mathrm{~m}$ as consisting of muddy fine sand:

interbedded with parallel laminated and bioturbated mud and sand.

Tucker (1781), Reineck and Singh (1980), and

Fieading (1986) describe distal prodelta deposits as consisting of laminateds fine grained muddy sediments, dominantly clay and silty clay, that can be transitional into either upper offshore or lower offshore shelf deposits. Frodelta sediments proximal to the delta front environment are 51 ightly more coarse grained and display a variety of bedforms including ripple bedding. small scale graded bedding, and lenticular laminations (Reineck and Singh, 1980).

Tucker (1981), Reineck and singh (1980), and

Feading (1956) describe delta front deposits as consisting of parallel laminated sand and silt, interbedded with parallel laminated and occasionally ripple laminated silty and sandy clays and organic detritus.

Deformational features found in the cores were classified to either of two origins: coring-related deformation, or ice-related deformation. Coring-related deformation encompass all structures that display a consistant concave-down nature, that is, laminations or bedding whose ends at the edge of the core were distinctly bent down as a result of penetration of the core barrel. Also any highly defarmed sediments at the bottom of a core were suspect, and were bel ieved to have been derived from suction created at the bottom of the core when it was extracted from the bottom. Ice-related deformational features vary greatly, but in general consist of laminations or bedding that display a consistant concave up nature, or any highly deformed area (ie. folded or offset) that is bounded on top and bottom by horizontally laminated or bedded sediments.

\section{HARRISON BAY SAMPLES}

CORE $V-13$

Core V-13 was extracted from $19 \mathrm{~m}$ of water, approximately $37 \mathrm{~km}$ from shore. Normal neritic deposition is represented by massive to laminated, bioturbated clay and 5 ilty clay deposits (Figure 4b, arrow 1) (Tucker, 1981; Reading, 1986). Interbedded, horizontally laminated. fine grained silty sands. probably represent intermittent coarser grained deposition by storm currents (Figure 4 b, arrow 2 ) (Tucker: 1981; Feading, 1986). Deformation in the 1 ower 


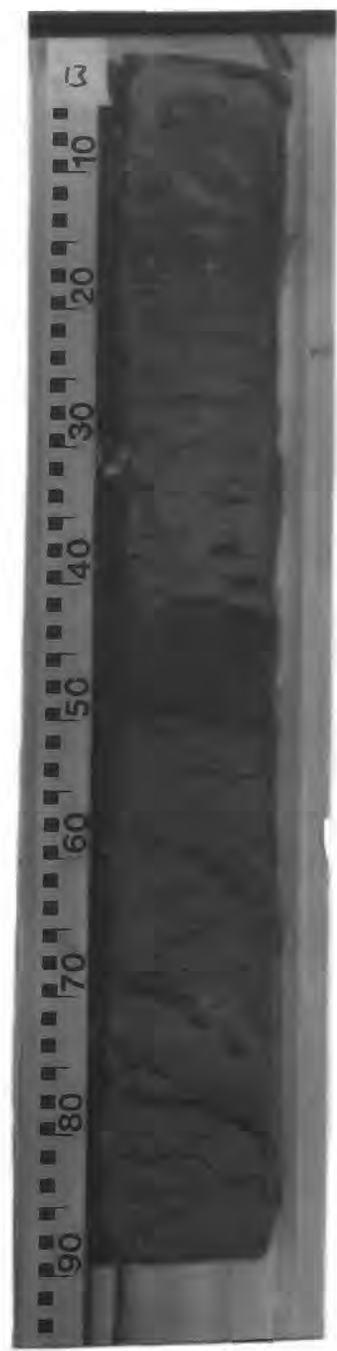

a

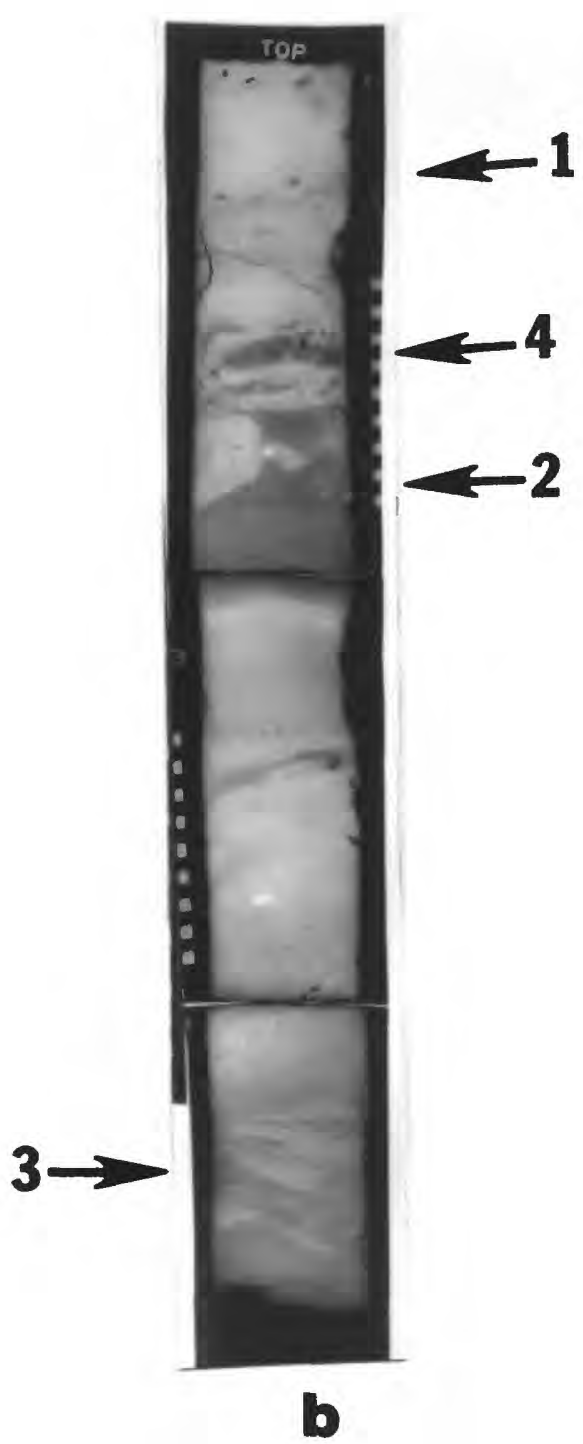

Figure $4 a$ and $b . \quad A$ and $t$ are peel and radiograph photographs respectively of core $V-13$. Arrow 1 points to clay, arrow 2 points to sand. Arrow 3 points to coring artifact in lower portion of core. Arrow 4 points to loaded contacts. Scale is in cm. 
part of this core is an artifact produced by coring (Figure 4b. arrow 3). The massive to laminated clay and silty clay, interbedded with thin units of fine grained silty sand are characteristics for deposition in a lower offshore shelf environment (Tucker, 1981; Reineck and Singh, 1980; Reading* 1986).

CORE $V-14$

Core V-14 was extracted from $15 \mathrm{~m}$ of water, approximately $29 \mathrm{~km}$ from shore. Normal neritic shelf deposition is represented by massive to slightly laminated. clay and silty clay (Tucker, 1981; Reading, 1960). Bedded fine sand, pebbles, and shell fragments in upper part of core probably represent deposition from storm currents (Fiqure $5 a$ and bo arrow 1) (Tucker, 1981; Reading. 1986). Deformation is a result of coring. The massive to laminated clay and silty clay, interbedded with thin units of fine sand containing pebbles and shell fragments may be indicative of deposition in a lower of shore shelf environment (Tucker, 1981; Reineck and Singh, 1980; Reading, 1986).

CORE $V-15$

Core V-15 was extracted from $12.4 \mathrm{~m}$ of water, approximately $20 \mathrm{~km}$ from shore. Normal neritic sedimentation is represented by sandy and silty clays (Reading: 1986). The presence of coarse material (sand and silt) incorporated with the clay is possibly indicative of higher terriginous input resulting from closer proximity to shore; or wave winnowing resulting from closer proximity to wave base. Horizontally laminated. fine to very fine grained sands and silty sands may represent deposition from storm currents and normal bottom currents (Tucker* 1981). Tabular crossbedding is present in middle part of core and is probably the result of sandwave propagation (Reineck and Singh: 1980) (Figure ba and b). This core is physically deformed in its lower part. Rip up clasts (Figure tb. arrow 1) are believed to be the result of ice gouging: and highly contorted bedding ( $F$ igure $b$, arrow 2 ) are believed to be the result of coring. The sandy and silty clays may be indicative of deposition in a lower offshore shelf environment, or an upper offshore shelf environment, and is probably a transitional zone between the two (Tucker, 1981; Reineck and Singh, 1980; Reading: 1986.

CORE $V-16$

Core V-16 was extracted from 11.5 in of water. approximately $16 \mathrm{~km}$ from shore. This core is composed of highly deformed clay, sandy clay, and sand (Figure 7a and b). Fhysical mixing of the sediment in this area 


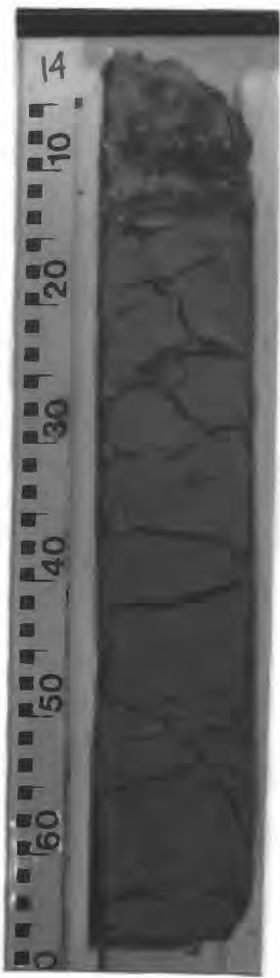

2

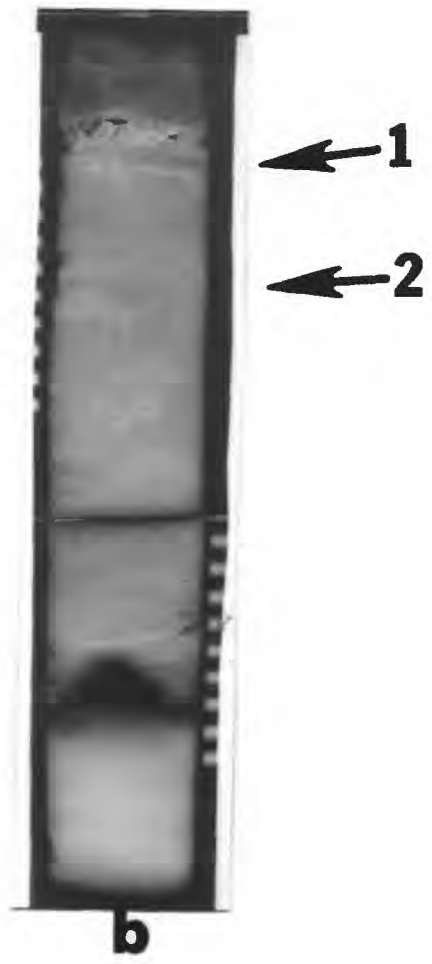

Figure $5 a$ and $b$. A and $b$ are peel and radiograph of core V-14. Arrow 1 points to bedided fine sand pebbles: and shell fragments in upper portion of core. Arrow 2 points to concave down laminations. Sicale is in $\mathrm{cm}$. 


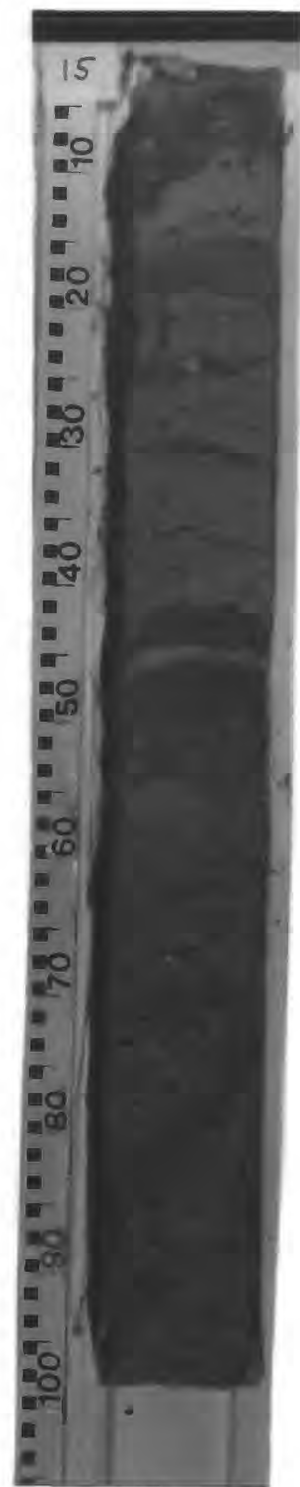

a
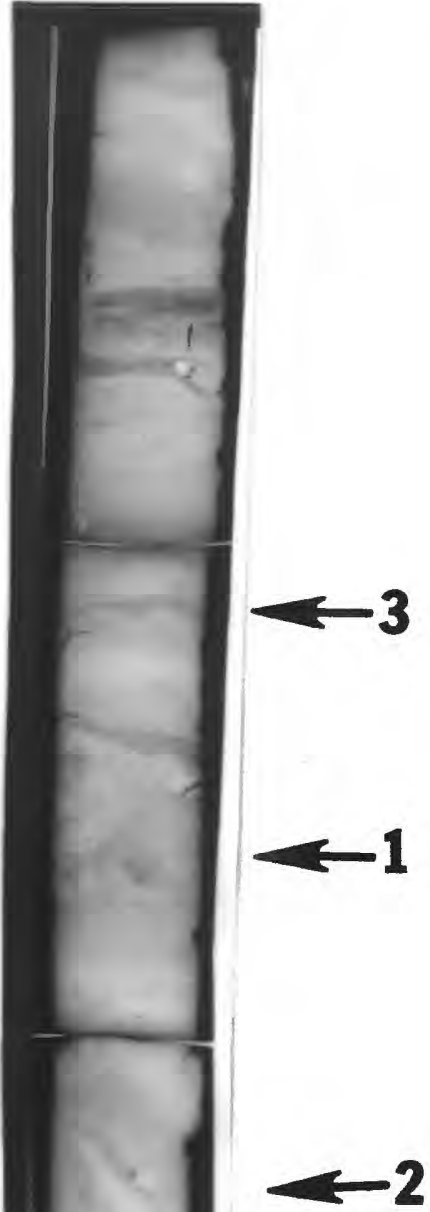

b

Figure ta and b. A and $b$ are peel and radiograph of core V-15. Arrow 1 points to rip-up clasts: arrow 2 points to deformed bedding. Arrow 3 points to loaded contacts. Sicale is in cm. 
due to ice gouging has obliterated the common structural and textural criteria normally used to classify sediments to an enviromment of deposition. Also the possible influence of prodelta muds from the colville river delta may have delivered a high percentage of clay to this depositional environment. Original horizontal laminations have been deformed into highly contorted bedding in the upper part of the core (Figure $7 b$, arrow 1) and have been physically folded and offset in the lower part of the core (Figure 7 b. arrow 2 ), probably by ice keel turbation. This core probably represents deposition in the upper of shore shelf environment, and has been classified based upon the position of the core in the transect relative to other cores in the study, and the water depth from which it was extractedy rather than by the sedimentological evidence.

\section{CORE $V-17$}

Core $V-17$ was extracted from $8.5 \mathrm{~m}$ of water. approximately $10 \mathrm{~km}$ from shore. This core is composed of highly deformed clay and silty clay (Figure ba and b). The normal sequence of horizontally laminated clays has been overprinted by the effects of ice gouging and most of the sediments in the core are deformed (Figure 8b. arrow 1\%. Some of the deformation in this core is likely the result of the coring procedure itselfs, however, only the concave down laminations (Figure Bb. arrow $z$ may be directly assigned to this category. The overall fine grained character of the sediments in this core relative to the water depth from which it was extracted and its proximity to the Colville River delta is indicative of a prodelta depositional environment (Reineck and Singh. 1980; Reading, 1986).

\section{CORE $V-18$}

Core $V-1 B$ was extracted from $3.3 \mathrm{~m}$ of water, approximately $9 \mathrm{~km}$ from shore. The upper portion of this core consists of horizontally laminated clay, sandy clay, and sand interbeds with high organic content (Figure $9 a$ and $b$ ). Cross-laminated and $r i p p l e$ cross-laminated sands are abundant in this portion of the core as well as thin beds ( 2 cm or less) of organic detritus. Truncation of horizontal and cross-laminations is present resulting in small cut and fill structures. The thin horizontally laminated clay and cross laminated sand interbeds and high organic content in this portion of the core may be indicative of the delta front depositional environment (Fiqure $\%$ b. arrow 1) (Tucker, 1981; Fineck and Singh, 1980; Feading: 19es).

The lower portion of this core is composed of 


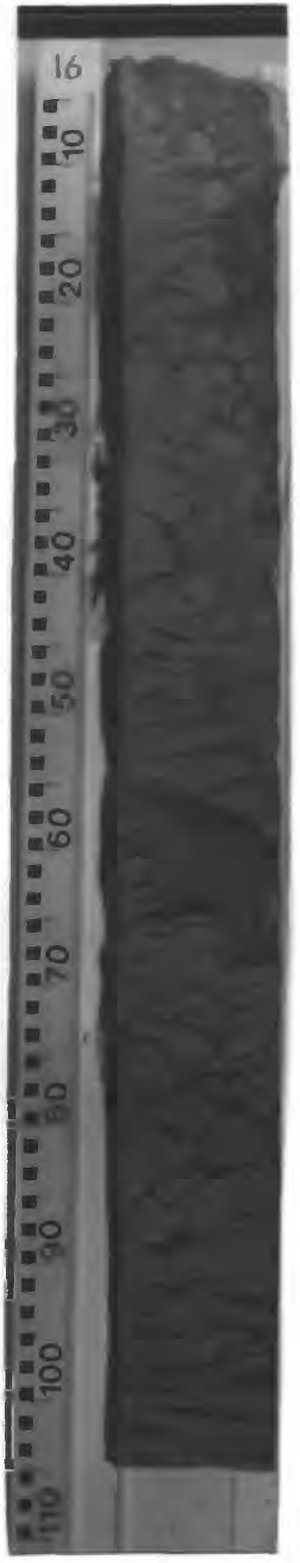

a

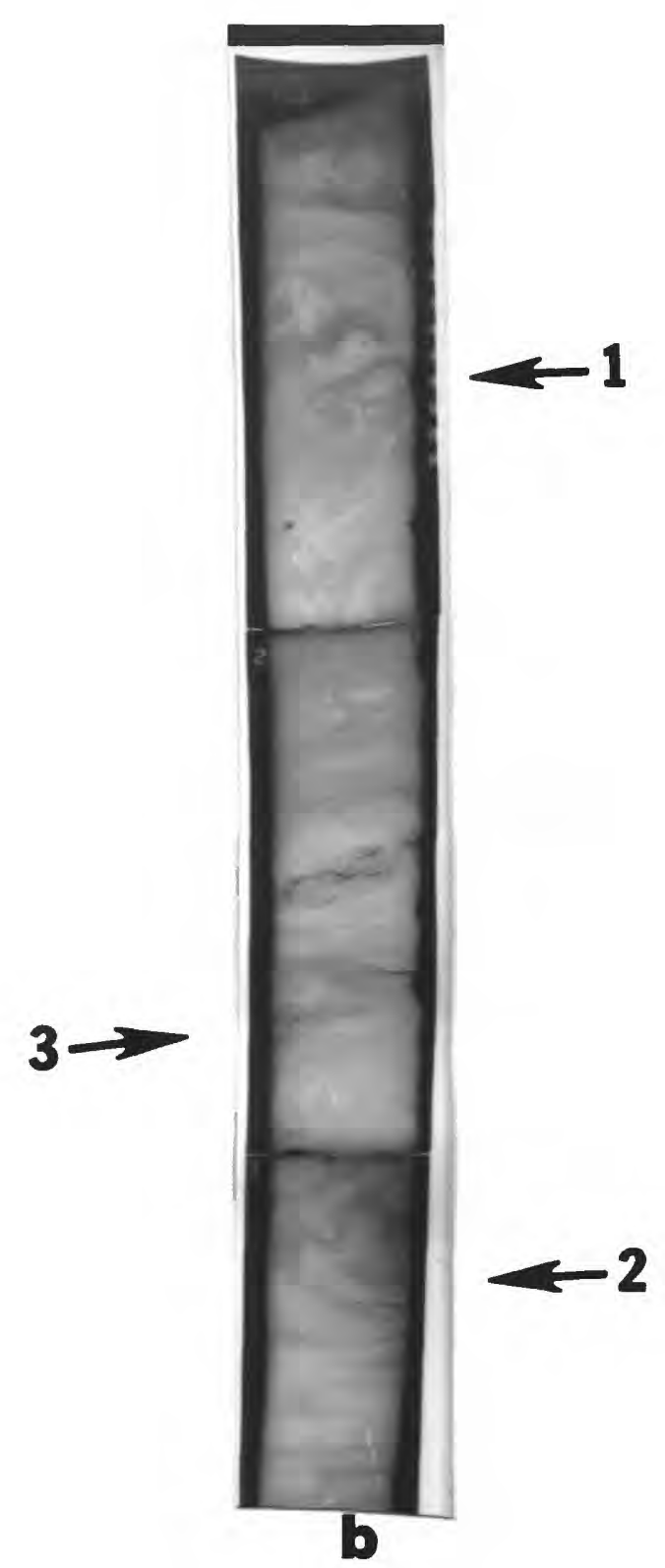

Figure $7 a$ and $b$. A and b are peel and radiograph of core V-16. Arrow 1 points to highly deformed bedding in upper portion of core. Arrow 2 points to folded and faulted bedding in lower portion of core. Arrow 3 points to small rip-up clast incorporated in folded beds. Sicale is in cm. 


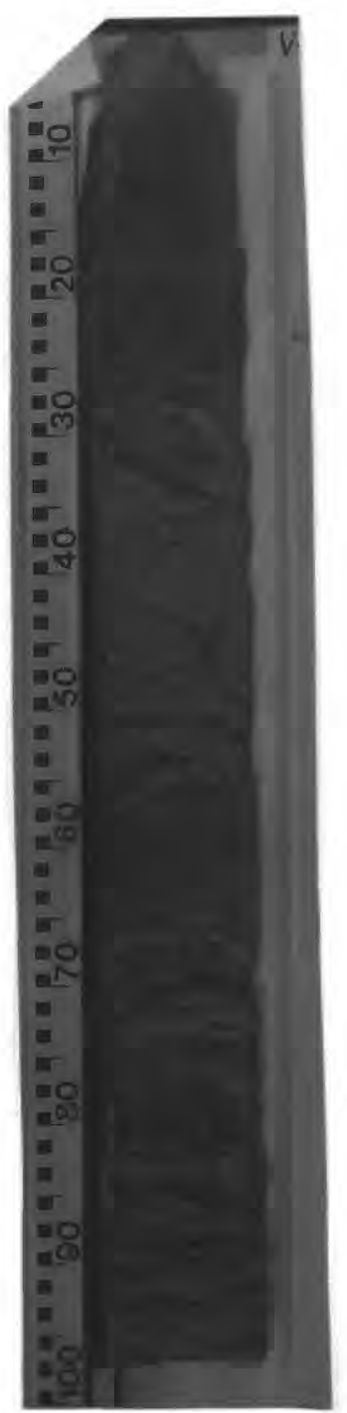

a

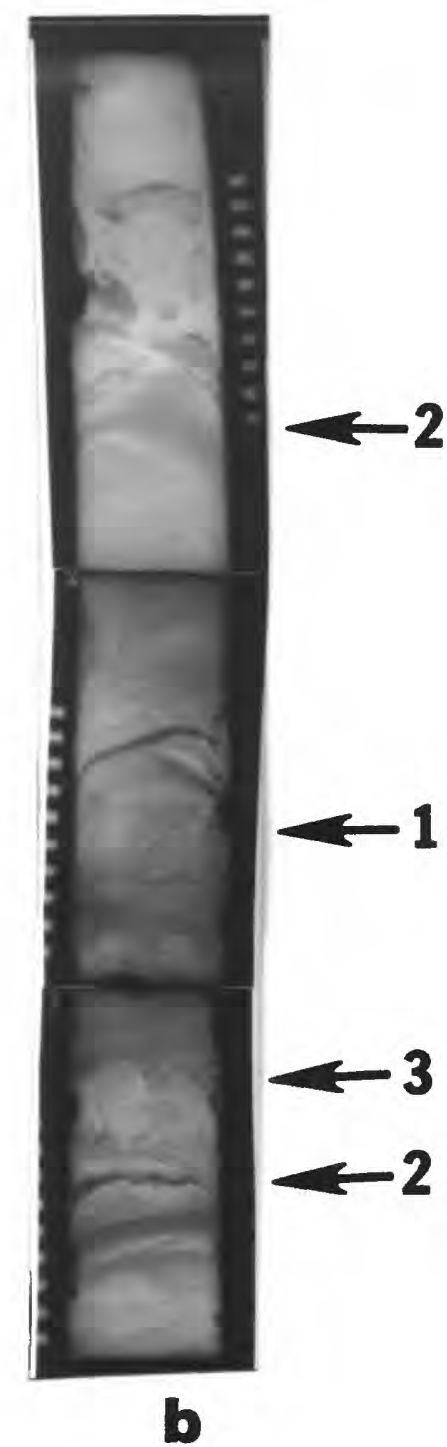

b

Figure Ea and b. A and b are peel and radiograph of core V-17. Arrow 1 points to probable ice gouge related deformation. Arrou 2 points to coring derived deformation. Arrow 3 points to rip up clasts. Scale is in $\mathrm{cm}$. 

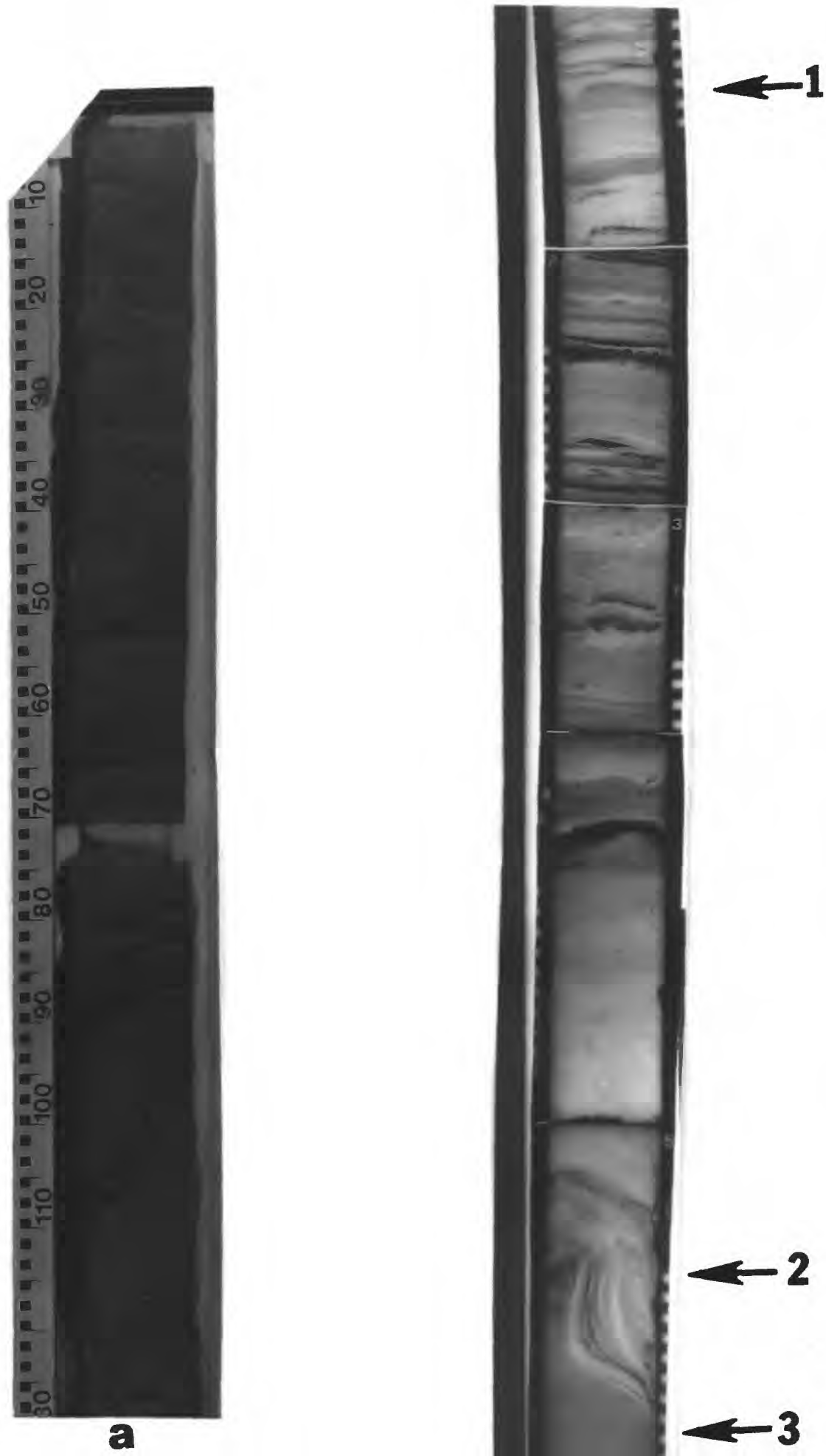

yon

-

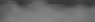
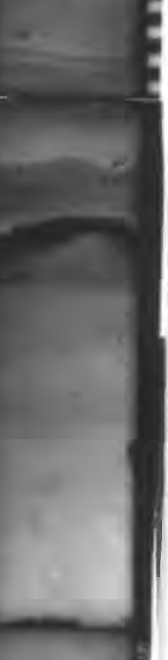

$=$

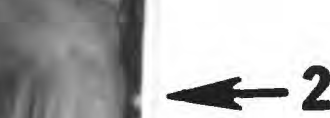

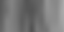
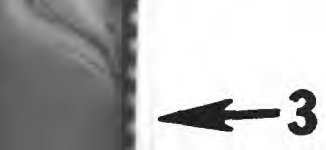

\section{b}

Figure $9 a$ and $b$. A and b are peel and radiograph of core V-18. Arrow 1 points to horizontally laminated sands: silts: and clays of the delta front. Arrow 2 points to highly deformed bedding that may be a result of ice gouging. Arrow 3 points to clay with abundant rootlets that may represent a subaerially exposed marsh deposit. Sicale is in cm. 
massive clay and sandy clay beds with few sand and organic interbeds. The 1 ower $50 \mathrm{~cm}$ of the core shows extreme deformation of a sandy unit above a massive clay unit with abundant rootlets and plant stems (Figure $9 \mathrm{~b}$. arrow 2). The presence of the rootlets may indicate that this portion of the core was a mat of tundra vegetation that has subsequently been buried. However. because this part of the core is dominantly mud (approximately $85 \%$ ), and a tundra mat would most 1 ikely contain a larger organic component (ie. $15 \%$ organics). this interpretation is improbable. The presence of rootlets in mud may indicate subaerial exposure (Reineck and singh, 1980; Reading, 1986, and this portion of the core therefore may represent deposition in a tidal marsh environment (Figure $9 b$, arrow 3) (Reineck and Singh. 1980; Reading: 1986; Tucker, 1981).

\section{CORE V-19}

Core $V-19$ was not physically available for study in this project, but prior description of this core by Barnes and Reimnitz, and its position in the sampling transect warrants the discussion of the depositional environment for this sample.

Core V-19 was extracted from the delta front in $2 \mathrm{~m}$ of water. approximately $7 \mathrm{~km}$ from shore. The core consists of horizontally laminated, medium to fine grained sand, clayey sand, clay, and organic interbeds (Figure 10a and b). Some bioturbation is seen in the upper portion of the cores and ripple cross-lamination is present in the middle portion of the core (Figure $10 \mathrm{~b}$, arrow 2). A high percentage of coal concentrates is present in the sands as thin laminae and as component grains. The horizontally laminated sand, clay, and organic interbeds may be indicative of deposition in the delta front enviranment (Figure 10b, arrow 3) (Tueker: 1981; Reineck and Singh, 1980; Reading, 1996).

CORE $V-20$

Core V-20 was extracted from the delta front in 1.5 $m$ of water, approximately $3 \mathrm{~km}$ from shore. The core consists of horizontally laminated sand, sandy clay* clay, and organic interbeds (Figure 11 a and b). Areas of mottling and possible bioturbation are present. The horizontally laminated sand, clay and organic interbeds may be indicative of deposition in the delta front environment (Figure 11b: arrow 1) (Tucker, 1981; Reineck: and Singh, 1980; Reading, 1986). A $25 \mathrm{~cm} 1 \mathrm{ang}$, 1 -shaped fold is present in the upper half of the core (Figure $11 \mathrm{~b}$, arrou 2 ), as well as a truncated overturned fold in the lower half (Figure $11 \mathrm{~b}$, arrow 3). These structures are believed to be the result of ice-keel turbation. 


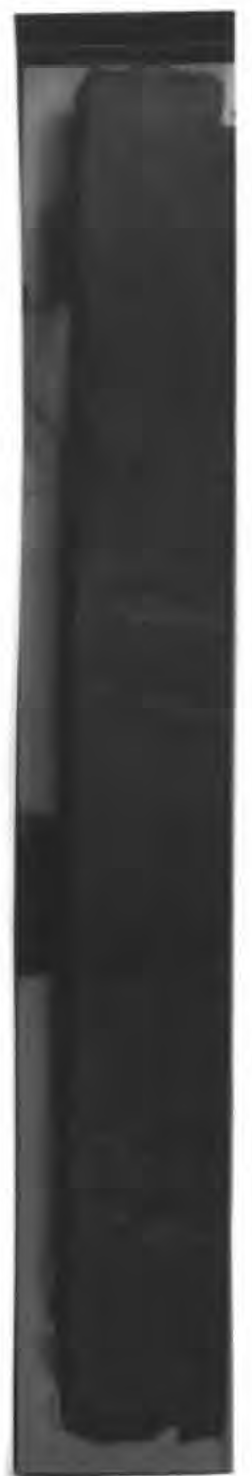

a

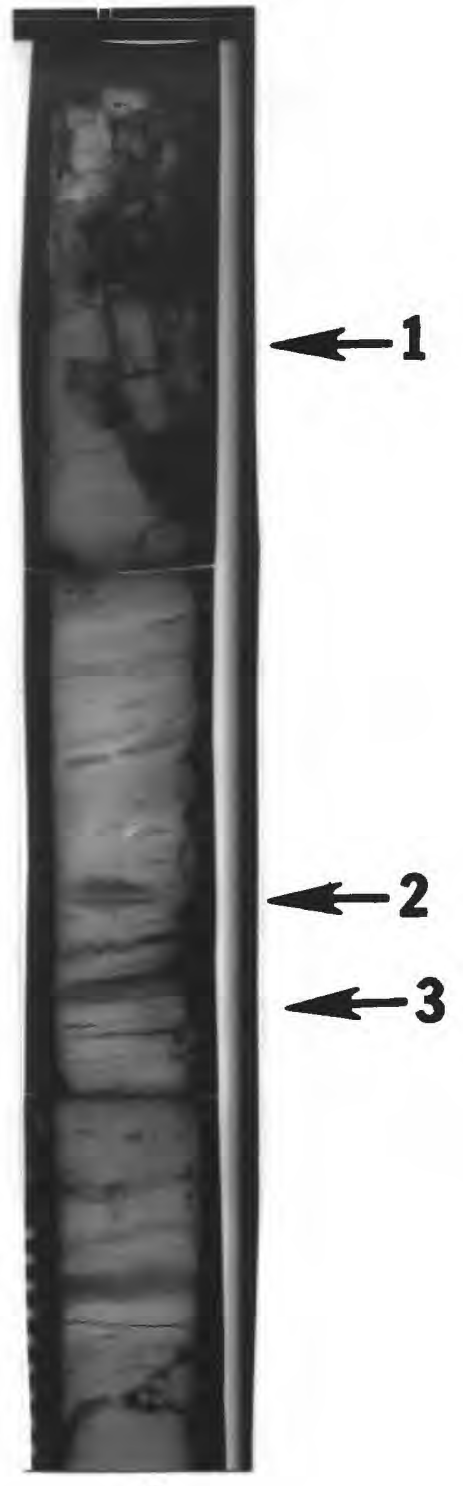

b

Figure 10 a and $b$. A and b are peel and radiograph of core V-19. Arrow 1 points to large burrow in upper portion of core. Arrow 2 points to cross laminations. Arrow 3 points to horizontally laminated sands and silts of the delta front. Sicale is in cm. 

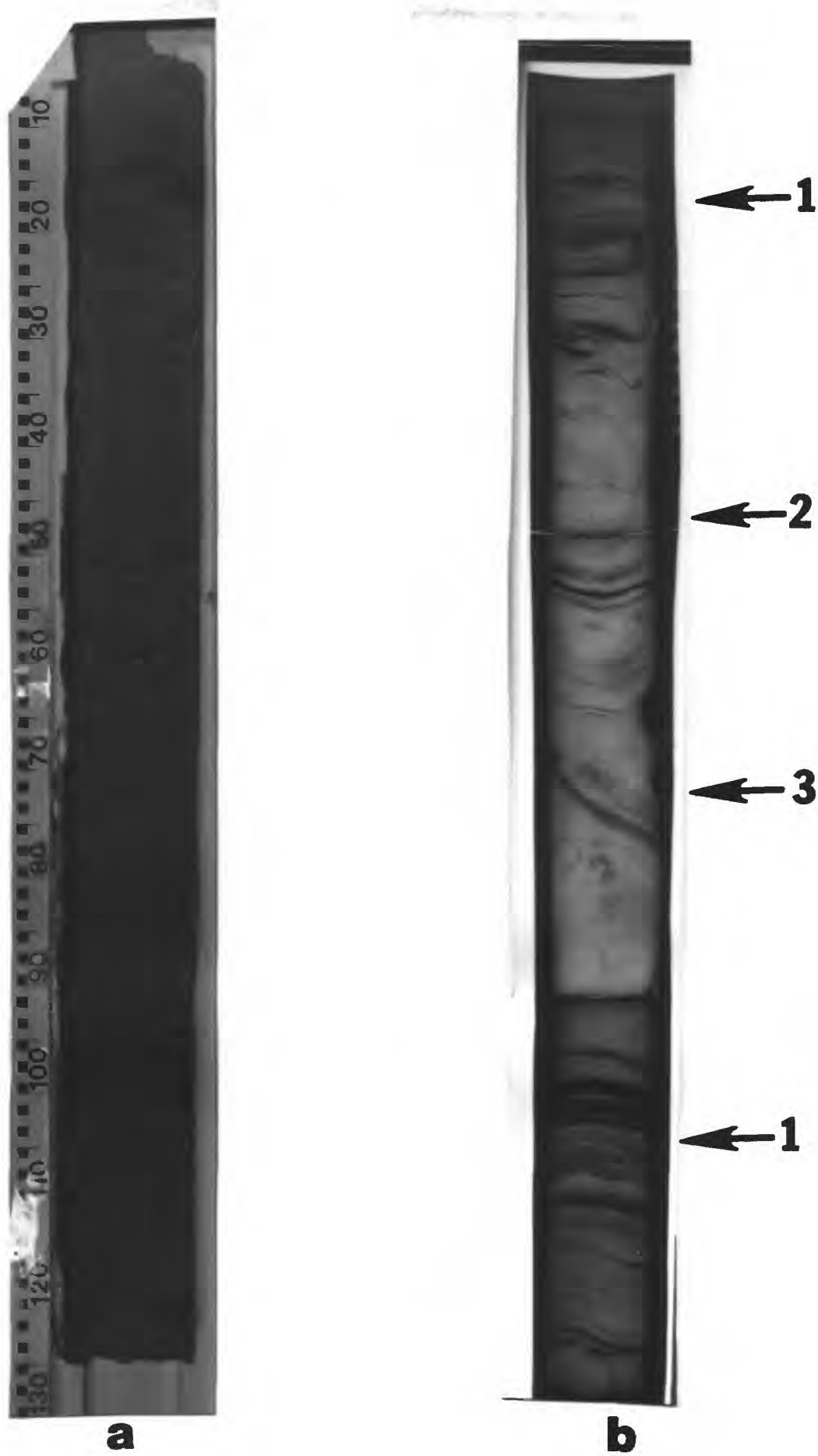

Figure $11 a$ and $b$. A and $b$ are peel and radiograph of core V-20. Arrow 1 points to undeformed horizontally laminated sediments of the delta front. Arrow 2 points to large box fold in upper portion of core. Arrou 3 points to truncated overturned fold in lower portion of core. Scale is in $\mathrm{cm}$. 
CORE $V-21$

Core V-21 was extracted from $4 \mathrm{~m}$ of water: approximately $19 \mathrm{~km}$ from shore. The core consists of horizontally laminated sand, clay, and organic interbeds commonly indicative of the delta front depositional environment (Figure 12a and b) (Tucker, 1981; Feineck and singh. 1980; Feading: 1986). Clay units in the upper portion of the core are extensively bioturbated and mottled (Figure 12b, arrow 1). Wavy and contorted contacts indicative of ice overloading are dominant (Figure 12b: arrow 2 ). The upper $25 \mathrm{~cm}$ of the core displays highly contorted and deformed bedding (Figure $12 \mathrm{~b}$ : arrow 3 , and these 5 tructures are believed to have resulted from ice gouging.

CORE $V-22$

Core $V-22$ was extracted from $6 m$ of water, approximately $15 \mathrm{~km}$ from shore. The upper portion of this core consists of horizontal to steeply dipping laminated and cross 1 aminated sands. The sands are relatively clean. but contain visible fibrous organic matter. At $50 \mathrm{~cm}$ a large bedform consisting of planar crossbeds and ripple cross laminations exist. A minor portion of this structure consists of well bedded, cross and planar laminated peat. This portion of the core represents a shoaling upward of sediments and is indicative of deposition in a subaqueous distributary mouth bar (Figure 13b: arrow 1) (Feineck and singh, 1980; Reading: 1986). The lower portion of this core consists of horizontally laminated. partially deformed. sand, clay, and organic interbeds which may suggest deposition in the delta front depositional environment (Figure 13b: arrow 2 ) (Tucker, 1981; Reineck and Singh: 1980; Reading: 1986). Some bioturbation is evident in this portion of the core, and organic content is highly visible.

\section{CORE $V-23$}

core V-23 was extracted from the delta front in $1 \mathrm{~m}$ of water = approximately $6 \mathrm{~km}$ from shore. The core consists of horizontally laminated and ripple cross-laminated sand, clay, and organic interbeds (Fiqure 14b, arrows). Some climbing ripple cross laminations are evident. Abraded twigs and plant stems are abundant in the upper portion of the lower hal $f$ of the core. Bioturbation and mottling are restricted to a few small units. No deformation is seen in the core: al though some wavy contacts that may be indicative of ice-overloading do exist (Figure 14a and b). The horizontal and ripple cross laminated sand. clay and organic interbeds may be indicative of deposition in the 


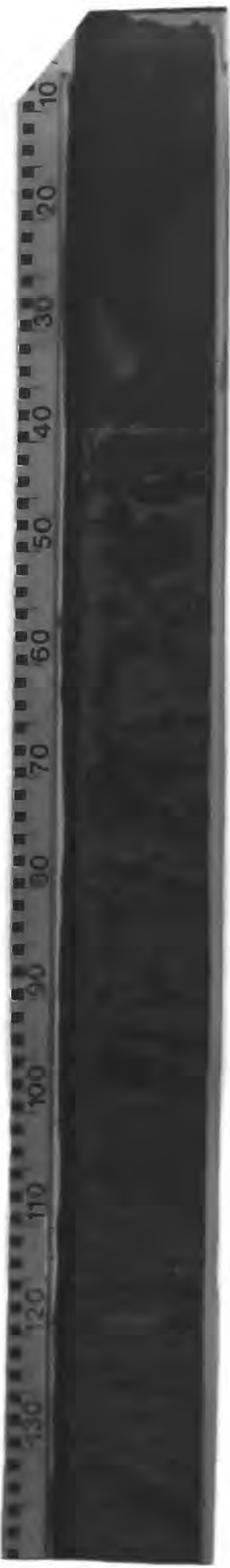

a

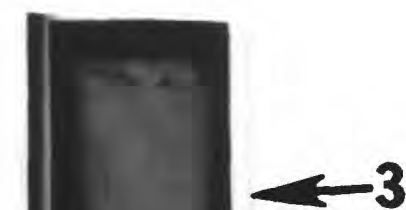

$\leftarrow 1$

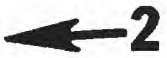

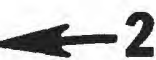




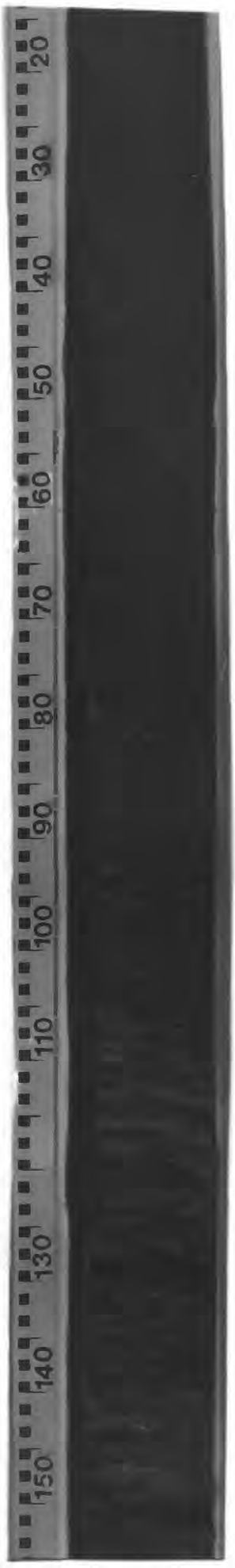

a

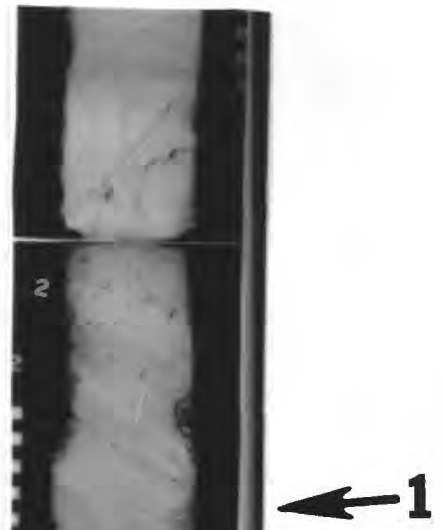

2

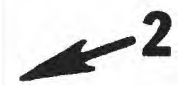

Figure 13a and $b$. A and $b$ are peel and radiograph of core V-22. Arrow 1 points to steeply dipping laminated and cross 1 aminated sands of the distributary mouth bar. Arrow 2 points to horizontally laminated sediments of the delta front. Scale is in cm. 


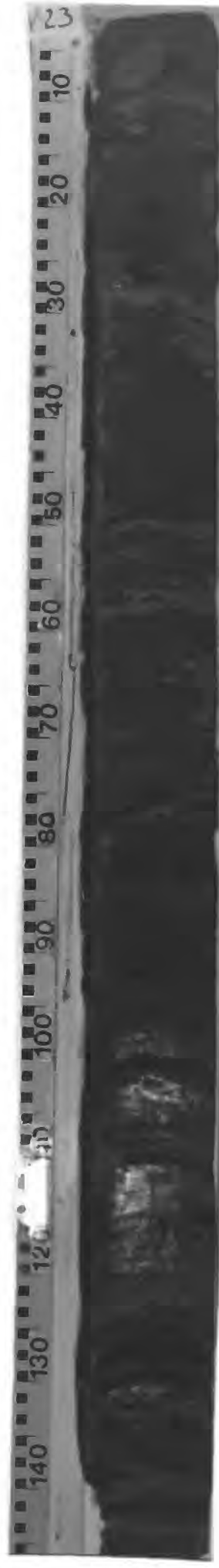

a

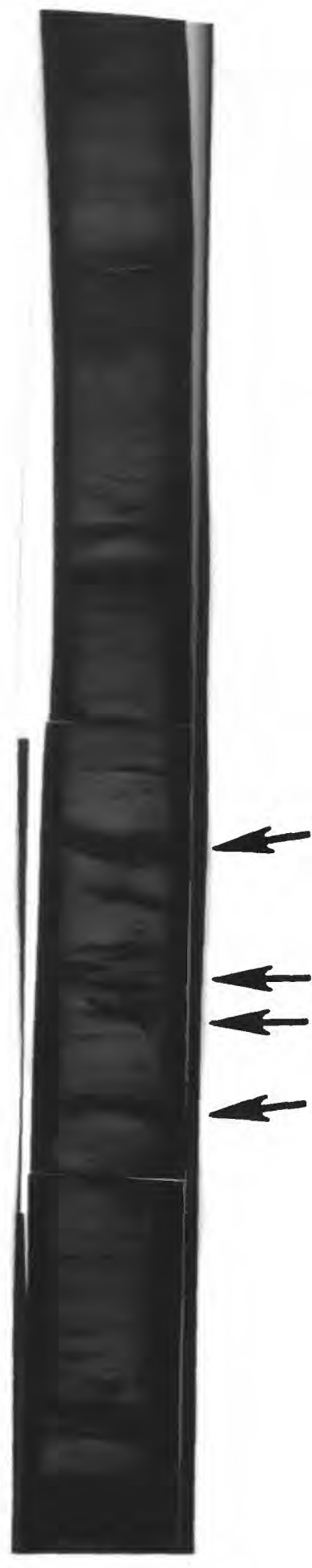

b

Figure 14a and $t .=A$ and $b$ are peel and radiograph of core $V-23$. Arrow points to dark areas which represent organic intertieds. Scale is in $\mathrm{cm}$. 
delta front environment (Turker, 1981; Reineck and Singh, 1980: Reading, 1986. .

\section{CORE $V-53$}

Core $V-53$ was extracted from 13 m of water, approximately $20 \mathrm{~km}$ from shore. The core consists of horizontally laminated sand, sandy clay, and clay interbeds. The sands are clean, lensoidal and cross laminated in part, and may be the result of storm currents and current reworking and suggest deposition in the upper offshore environment (Reineck and Singh: 1980; Reading, 1986). The horizontally laminated clay units represent normal neritic deposition from suspension settling, which is believed to have been influenced by the high influx of suspended sediment from the prodelta region (Feineck and Singh, 1980; Feading, 1986) (Figure $15 a$ and b). The bottom portion of this core is slightly deformed, most 1 ikely from coring (Figure 15b, arrow 1).

\section{CORE V-55}

Core V-55 was extracted from $7 \mathrm{~m}$ of water? approximately $10 \mathrm{~km}$ from shore. The upper hal of this core consists dominantly of massive to partially laminated clay, interbedded with thin sand units (Figure $16 a$ and $b$, arrow 1 that may be indicative of deposition in the prodelta environment (Tucker, 1981; Reineck and Singh, 1980; Reading: 1986). The clay is believed to have been deposited from suspension by sediment-laden water of the river (Reineck and Singh. 1980; Reading, 1986), and by current and ice reworking (Reimnitz and Barnes, 1974: Barnes et al : 1979). The sand units may be derived from storm-generated currents, or strong current reworking (Reineck and Singh, 1900; Reading, 1986). The lower half of this core consists of thin, horizontally laminated sand, sandy clay, and clay units that may be indicative of the delta front environment (Figure 16b, arrow 2 ) (Tucker, 1981; Reineck and Singh, 1980; Reading, 1986). Minor cross bedding and wavy contacts are present, organir material is notably absent. The middle portion of this core shows a high degree of deformation that is bourded on top and bottom by horizontally laminated sediments, most 1 ikely the result of ice gouging (Figure 16b, arrow 3).

CORE $V-7 t$

Core $V-70$ was extracted from $10.7 \mathrm{~m}$ of water. approximately $12 \mathrm{~km}$ from shore. This core was reported by Barnes and Reimnitz (1977) to have been taken on top of a sediment wave, (which were typically 1 ess than $1 \mathrm{~m}$ high) a hydraulically produced mega-ripple bedform. The upper $1 / 3$ of the core consists of finely laminated. 

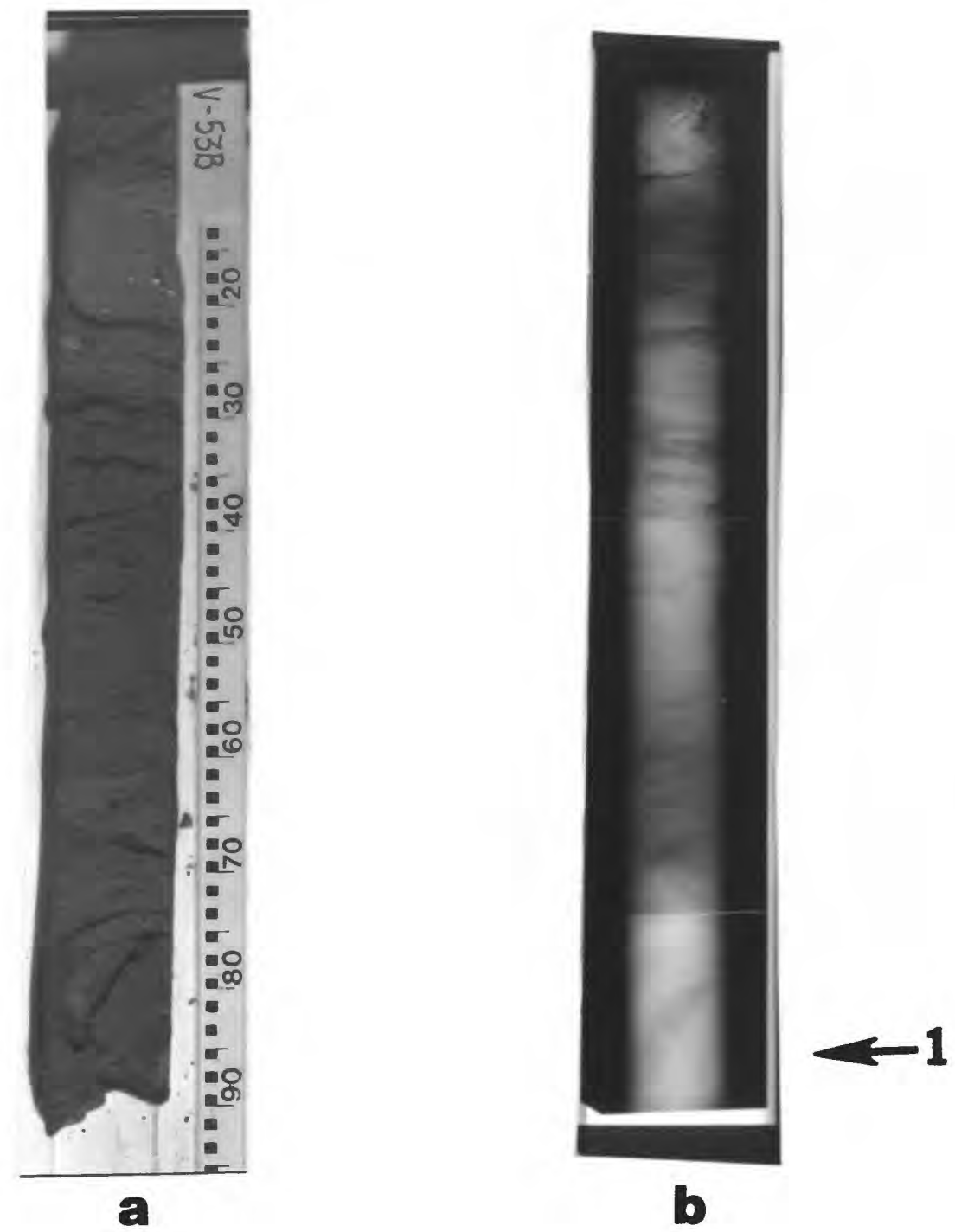

Figure 15 a and $b$. A and b are peel and radiograph of core V-53. Arrou 1 points to coring artifact in lower portion of core. Sicale is in cm. 


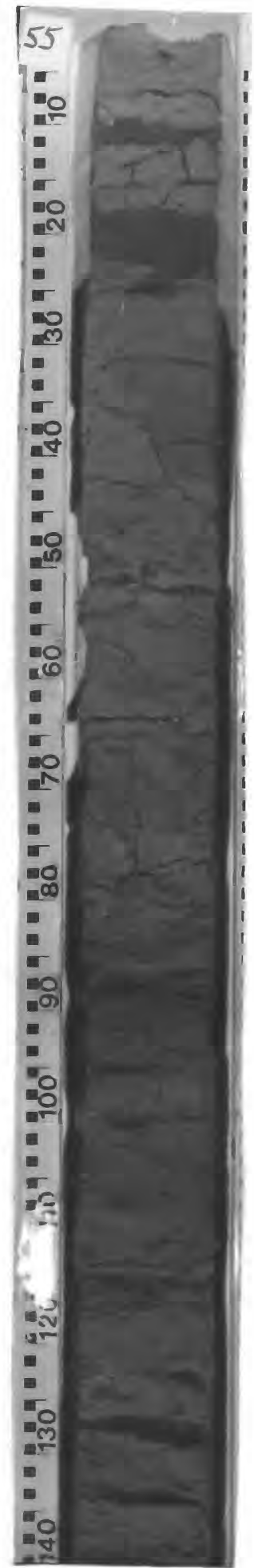

a

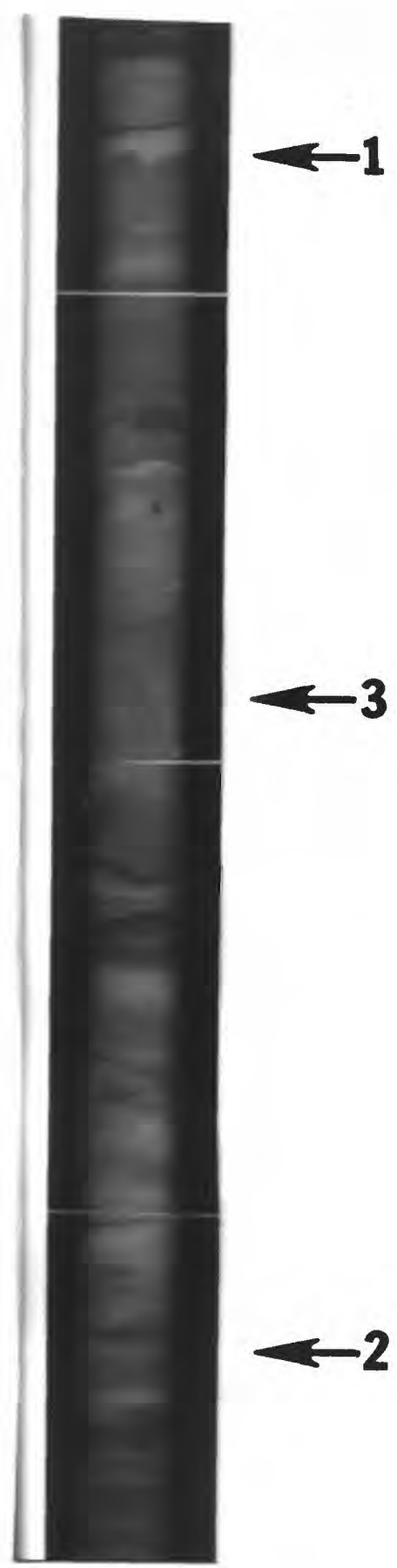

b

Figure 16a and $b$. A and $b$ are peel and radiograph of core V-5s. Arrow 1 points to massive to partially laminated sediments of the prodelta, and loaded deformed contact. Arrow 2 points to horizontally laminated sedimerts of the delta front. Arrow 3 points to protable ice deformation. Scale is in $\mathrm{cm}$. 
medium to coarse-grained clean sand with minor silt interbeds. These sediments probably represent deposition in the sediment wave that was sampled (Figure 17, arrow 1). A prominent scour and fill structure is present in the middle of this portion and all

laminations are pronouncedly deformed into a concave-up

fold structure. deformation is probably the result of ice gouging (Figure 17, arrow 2 ).

The lower $2 / 3$ of this core consists of highly bioturbated and mottled clay and finely laminated sand interbeds suggesting deposition in the delta front environment (Figure 17: arrow 3) (Tuckers 1981; Reineck and Singh: 1980; Reading, 1986). The clay contains abundant shell fragments and whole shells and displays no bedding. The sand is horizontally and trough cross-laminateds medium to fine graineds and olean. Some $r$ ip-up clasts of clay with high organic content are present.

\section{DISCISSSION}

DEFOSITIONAL ENUIRONMENTS

The analysis of cores in this study was under taken with two major questions in mind: 1) What sedimentary structures. texturess and 1 ithologies characterize deposition in an aretic shelf environment that is encroached upon by a major fluvial system: and 2) What type of deformational structures may be overprinted on the sediments in this environment through ice-keel turbation?

It was assumed that the sedimentological character of each core reflected its depositional environment when sampled. This assumption appears to be well founded based on the sedimentological evidence present in the cores. This assumption fails in the event that the sea floor in the study area is erosional, in which case the depositional environments described may reflect Early Holocene deposition rather than present processes. In all cases, the sedimentologiral characteristics of each core were compared to the sedimentological characteristics of similar environments (i.e.. water depth, distance from shore, sediment influx) on 1 ower latitude shelves that have been well documented in the literature (Tucker: 1981; Reineck and Singh, 1980;

Reading 1986) . In any instances where sedimentary features in the cores diverged from documented features of the particular depositional environment in question. and no other source of information could be found that described such a feature, it was assumed that such a feature is peculiar to deposition in that environment on high latitude shelves. The following discussion is a summary of general sedimentological features displayed 


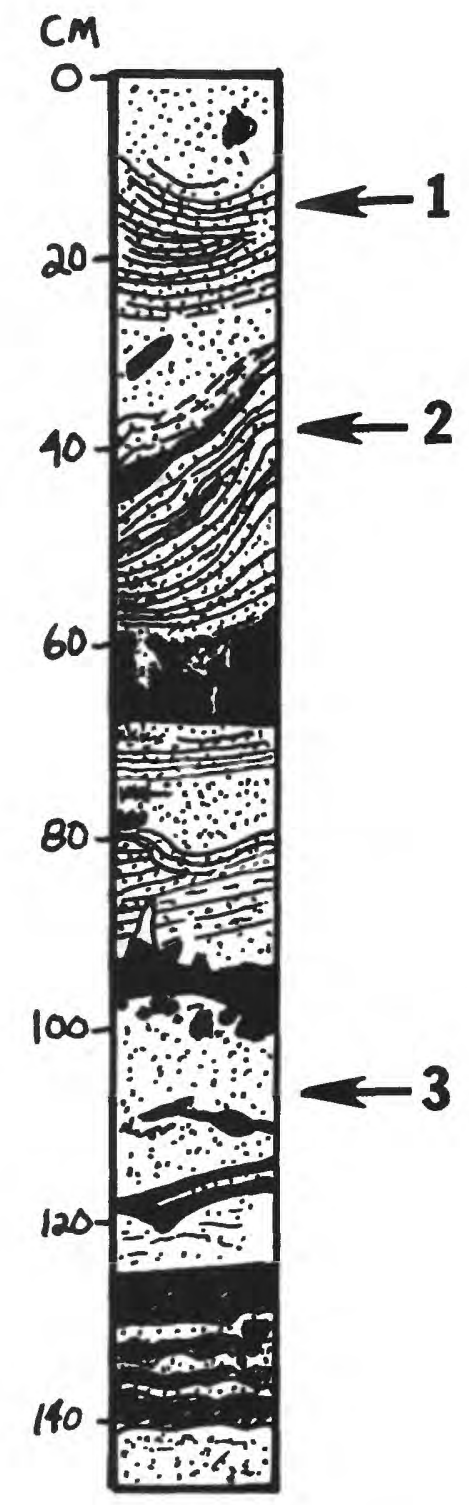

Figure 17. Sketch of core V-76. Peel and radiograph photographs not available for this core. Arrow 1 points to sediment wave deposit. Arrow 2 points to highly deformed laminations. Arrow 3 points to delta front deposits. Scale is in centimeters. 
in the offshore to onshore transect through the study area.

The water depths: depositional environments: and stratigraphy of cores $V-13, V-14$, and $V-15$ compared well to the lower offshore shelf environment.

Sediments described from 1 ow latitude. lower offshore shel $\mathrm{f}$ environment in depths of 10 to $30 \mathrm{~m}$ : qenerally consist of muds, laminated to highly bioturbated. derived from suspension settling: interbedded with parallel laminated. occasionally ripple laminated. fine grained sands. derived from storm generated currents (Tucker = 1981: Reineck and Singh: 1980; Reading. 1986). Cores $V-13$ and $V-14$ consist of massive to faintly laminated clays interbedded with horizontally 1 aminated fine grained sands (Figures 4 and 5). Core V-15 displayed characteristics of both 1 ower and upper offshore shelf environments (Figure $G$ ). The upper offshore shelf is characterized by muddy fine sand admixed and interbedded with the sediments (mud and sand) of the lower offshore shel $f$ (Reineck and Singh, 1980: Reading: 1986).

Determining the depositional environment for core $V-1 \mathrm{k}, 4 \mathrm{~km}$ inshore of zore $V-15$ (Figure $1 \mathrm{~b}$ ) was complicated by the overprinted deformation associated with ice gouging. The assignation of this core to the upper offshore shelf environment relies more on general I ithologic trend relative to position with other cores in the transect, artual position of core $V-16$ in the transect and the water depth $(11.5 \mathrm{~m})$ from which it was extracted. Core $V-1 t$ has a higher percentage (visual estimate) of sand than does core $V-15$. In the classical shelf environment where ice does not play a dominant role, the upper offshore shelf zone proximal to the lower shoreface (Reineck and Singh. 1980) would contain thicker and more abundant sand interbeds than the distal upper of shore shelf (Reineck and Singh, 19g0; Reading. 1986). In core $V-16$ the higher percentage of sand that might normally be associated with proximal upper offshore shelf is present, but clay appears to be dominant in the 1 ithology. It is this author"s belief that the apparent abundance of clay is due to the proximity of the Colville Delta and the influence of prodelta muds in the area. The sand present is not in the form of interteds, but rather as an admixture with clays, believed to result from vigorous reworking by ice and currents. Barnes et al = (1979) hypothesized that bedding would not survive in an area of vigorous seabed scouring by grounded ice keels. Perhaps the distinct units of sand and clay seen in core $V-13$ and $V-14$ are reworked by ice gouging into the highly deformed sandy clay seen in core $V-16$ (Figure 7 ). Core $V-53$ is spatially located in the transect 
between, and to the east of, $V-15$ and $V-16$. While the core is from a similar setting as cores $V-15$ and $V-16$. it does not display the same characteristics of vigorous ice reworking shown in $V-15$ and $V-16$. Only the lower portion of the core displays distinct deformation and is composed of sandy clay (Figure 15b, arrow 1 ) . Cores $V-16$ and $V-53$ are believed to represent a transitional zone between upper offshore shelf deposition and prodelta deposition.

Cores $V-17$ through $V-23$, and $V-55$ were all extracted onshore of the $10 \mathrm{~m}$ isobath and show a trend from offshore to onshore of increasing degrees of fluvially dominated sedimentation. Cores $v-17$ and $v-55$ show a relative shoreward increase in clay content and a decrease in fine sand content (visual estimation) (Figure $B$ and 16 ) and represent the prodelta environment.

All of the cores taken landward of the $2 \mathrm{~m}$ isobath are conspicuously similar. Sedimentation at the $2 \mathrm{~m}$ isobath is a dramatic change from massive clays offshore to thin finely laminated clay and fine sand interbeds shoreward. It is this author"s opinion that the $2 \mathrm{~m}$ isobath represents the approximate seaward 1 imit of the delta front. Cores $V-18$ through $V-23$ all represent deposition on the delta front.

Cores $V-17$ through $V-23$, and $V-55$ were compared to the del ta front and prodelta environments described by Tucker (1981), Rieineck and Singh (1980), and Reading (1986). Figure $18 \mathrm{~B}$ and b shows cores taken from the Guadalupe Delta (from Feineck and Singh, 1780), displaying the characteristics of natural levee, marsh, delta front, and prodelta environments. Cores from the Colville Delta (Figures $8,9,10,11,12,13,14$, and 16) show a striking similarity with those of the Guadalupe Delta. The most marked similarity is that of the cores of the delta front and prodelta. The natural levee, and marsh environments were not cored in this study, and therefore no comparison can be made.

The sediments from the Colville Delta are generally more fine grained, but the overall similarity in the morphological character between the sets of cores is impressive.

In summary, the cores from Harrison Bay generally display a trend from offshore to onshore, of muds deposited from suspension settling. interbedded with fine sands derived from storm currents on the lower offshore shelf at depths greater than $10 \mathrm{~m}$ (Figure 17), to increasingly more sandy sediments to about the $10 \mathrm{~m}$ isobath (upper offshore shelf). In the vicinity of the $10 \mathrm{~m}$ isobath a transition zone betueen upper of fshore shelf and prodel ta environments is present. characterized by the muds of the prodelta admixed and 


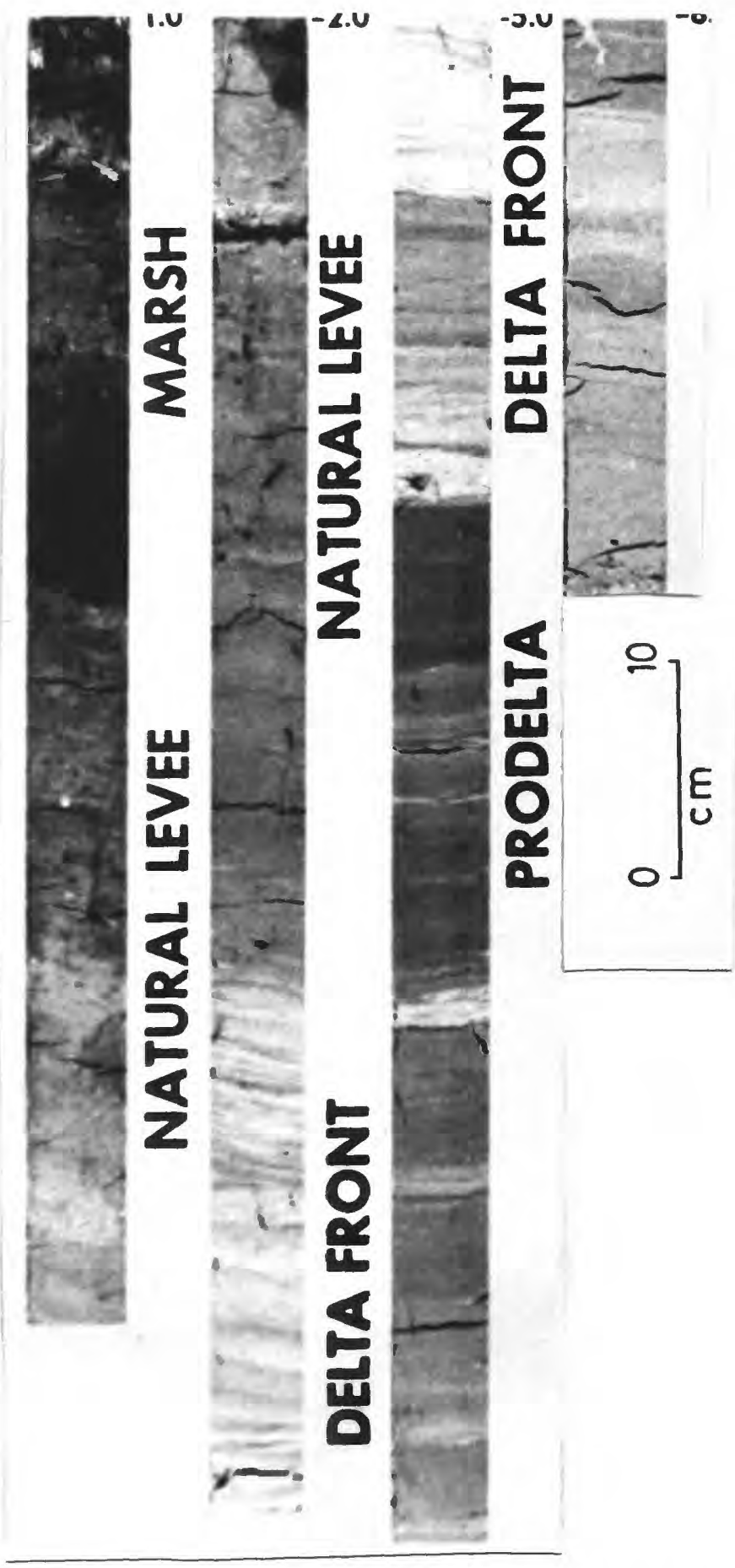

Figure 18a = Cores from the Guadalupe Delta showing characteristics of delta front, prodeltas and marsh deposits. Compare the characteristics of these cores with cores from the study area (From Reineck and Singh: 1980). 


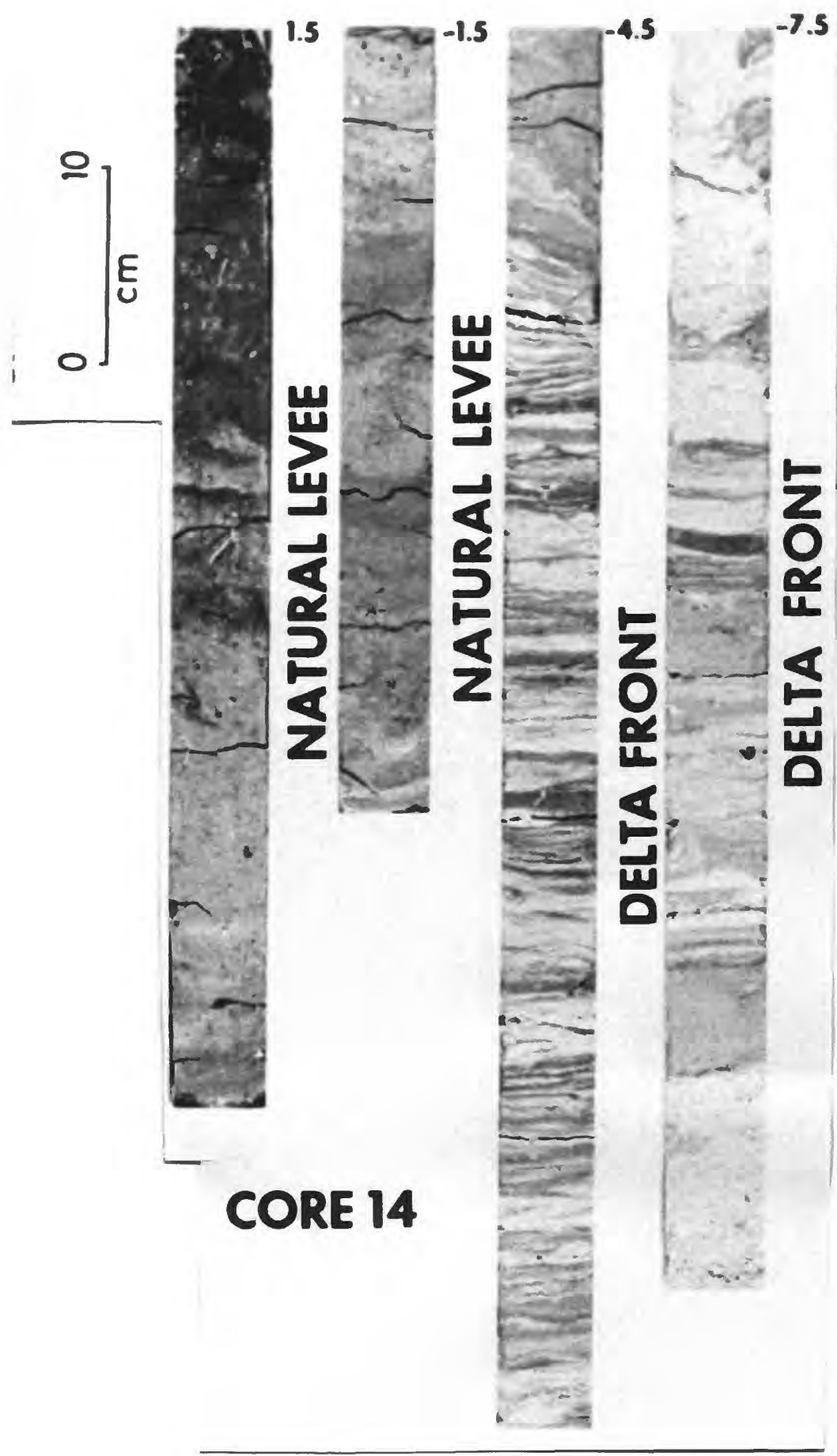

Figure 18b. More cores from the Guadalupe Delta. Compare these cores with cores from the study area (From Reineck and singh. 1980). 


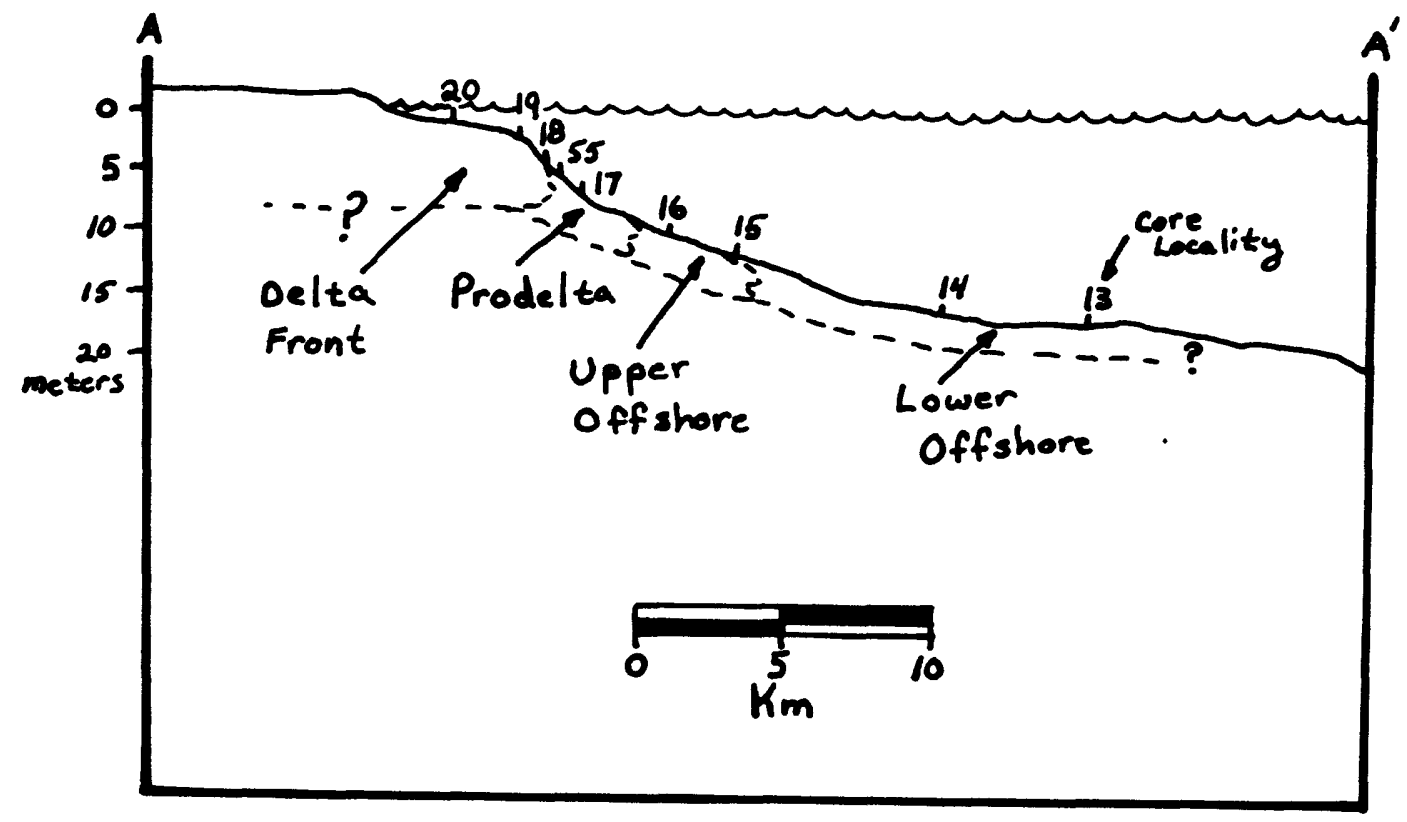

Figure 19. Shelf profile along ship's trackline and coring transect $\left(A-A^{\prime}\right)$ showing core localities and hypothetical facies associations. 
interbedded with the muddy fine sand of the upper offshore. Shoreward of the $10 \mathrm{~m}$ isobath to approximately the $2 \mathrm{~m}$ isobath is the prodelta enviromment characterized by partially laminated very fine grained sediments (Figure 19), and shoreward of the $2 \mathrm{~m}$ isobath is the delta front environment that is characterized by thin horizontally laminated interbeds of clay, sand, and organic detritus (Figure 19).

\section{ICE-RELATED DEFORMATION}

The literature on ico keel deformation of the seabed is sparse CReimnitz and Barnes, 1974; Barnes et al.: 197\%; Feineck and Singh. 1980). Models discussing the formation of ise gouges are abundant csee previous work section, however no models discussing seabed deformation associated with ice gouging have been found. The following hypothesis is proposed for ice-related deformation.

The process of ice qouging. regardless of genetic form (that is either pack-ice related or ice-tierg related) leaves evidence in the stratigraphic record in the form of either the preserved gouge or the deformation associated with the process of gouging. As an ice keel plows through the seabeds it leaves in its wake a groove cut into the soft sediments of the orean floor. As the ice keel passes through the sediment, two forces are azting simulaneously upon it. The horizontal force acting as the transport mechanism (i.e. wind: currents, rotation of the ice pack, etc.), and the vertical force based on the weight of the ice supported by the seabed due to qravity. In Fiqure $20 a$. Va represents the volume of ice above the waterline when the ice is completely buoyant (equilibrium), and Vb represents the volume of ice below the waterline at equilitirim. The mass of the ice above the waterine when the ice is not moving can then be represented by fa where Fal(Va $x$ density of sea ice) $x$ gravity. and the mass of the ice below the waterline can be represented by $\mathrm{Fb}$ where $\mathrm{Fb}=\mathrm{CVb} \mathrm{x}$ density of seawater - density of sea ice) $x$ gravity. The net force exerted downward (Fnet) then will be equal to Fnet = Fa-Fb. Fnet = when the buoyanicy forces acting on the ice belou the waterline balance with force exerted by the mass of the ice above the waterline. Because of the density difference between ice and water the ice floats with approximately $1 / 5$ th of its volume above the waterline (Kovacs and Mellor. 1974; Gross. 1992).

In the case where ice is touching the bottom (Fiqure 20b): Va becomes $V a+5 o m e$ newly exposed volume (Vnew) above the water after tourhing the bottom. here called Vi. The force then acting above the waterline (Fa) becomes $\mathrm{Fa}=$ ( (Va + Vnew) $x$ density of sea ice $x$ 

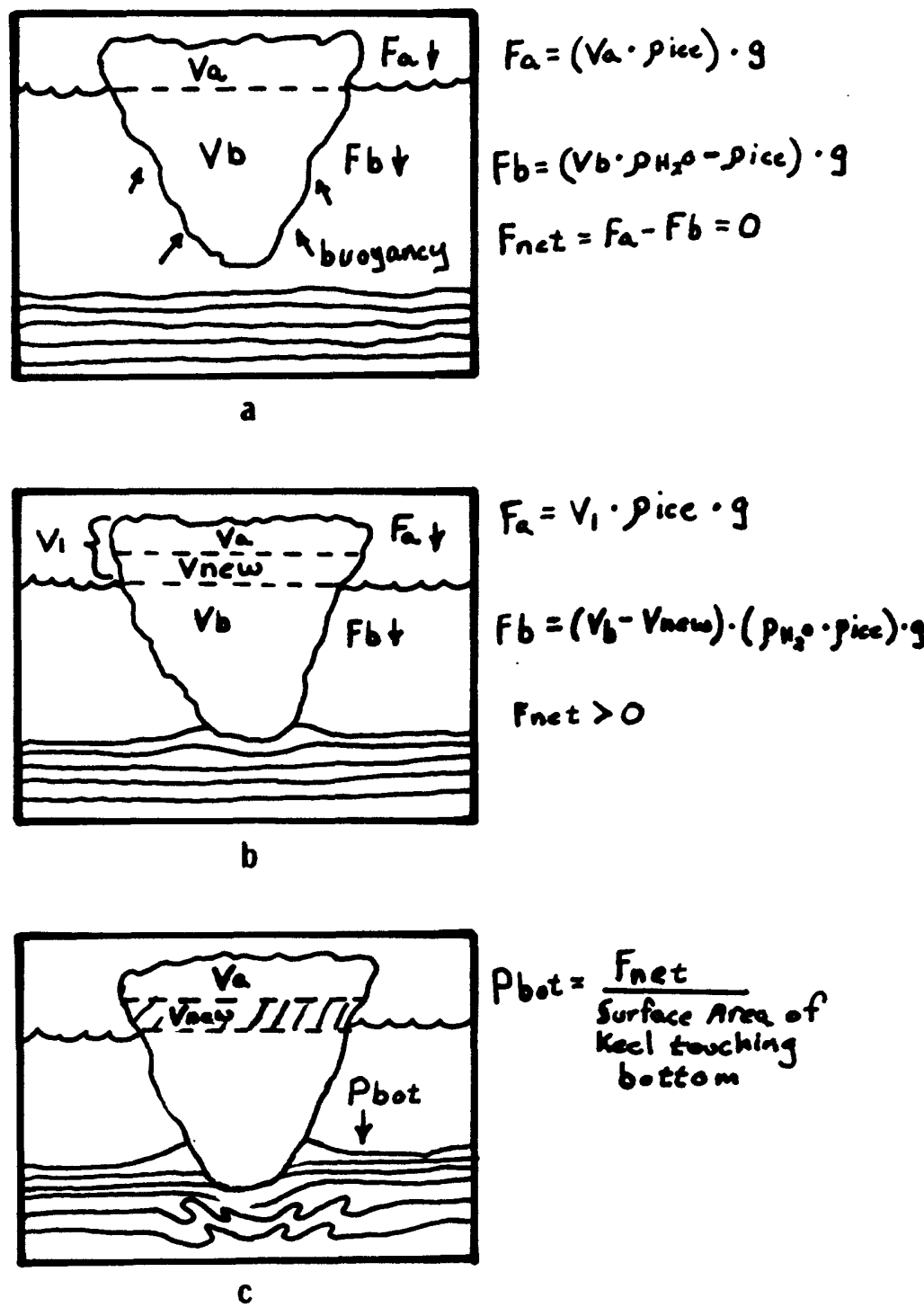

Figure 20 a through $20 \mathrm{c}$. Graphic representation of hypothetical model of ice gouging. A) Floating ice, Fa equals $\mathrm{Fb}$ so net force $=0$. B) Ice touching bottom, new total volume exposed above waterline is $V_{1}$ (Va + Vnew), Fa is not equal to $F b$ and the net force, Fnet, is greater than o by the amount of mass in Vnew. C.) Pbot is pressure exerted on bottom by ice keel. This model can be likened to a woman standing in high heels, large weight distributed over small surface area creates great pressures. 
gravity): and the force acting below the waterline is $F$ $=(V b-V n e w) \times$ (density of seawater) - (density of sea ice) $] \times$ (gravity). The net force acting on the bottom in this case is Fnet $=F a-F b$ where Fnet will be $>0$ by the amount of mass in Vnew.

If we now consider the net force acting on the bottom arid the disequilibrim between the size of the ice mass relative to the size of the ice keel contacting the bottom we can see that the forces acting on the bottom from a grounded ice keel can be tremendous. To look at this example in terms of pressure. let"s call the pressure exerted on the botton as Pbot. Pbot then becomes Fbot=Fnet/surface area of the ice kegl touching bottom.

A typical cross-sectional dimension of a prossure ridge is roughly $35 \mathrm{~m}$ wide at the waterling and the width of the lceel is roughly $5 \mathrm{~m}$ at the bottom (Kovacs and Mellor, 1974). Those proportions can bo likened to a woman wearing high heeled shoes. The iarge mass of the woman distributed over the very small surface area of the bottom of the high heel creates extremely large pressures. In the case of the ire keel, the large mass of ice above the waterline sistributed over the small surface area of the keel touching the bottom creates great pressures. In this case, the pressures exerted on the bottom by such a geometry are great, certainly enough to deform soft sediments.

There are obviously other factors that play a role in the deformation of any substrate, but this discussion is only a basic explanation and the inclusion of other factors here is beyond the scope of this report. For a more in-depth analysis of the physies and ice forces refer to Kovacs and Mellor (1974).

In all cases, except where ice iust touches bottom: some type of subsurface deformation probably oceurs in soft sediments. The combination of loading by the weight of the ices coupled with a horizontal translation. caused by transport processes. plous the seabed at the surface and may result in lateral subsurface movement of relatively soft and mobile sediments in response to loading pressuros exorted by the ice keel.

Deformation caused by ice keel overloading should range from simple load structures to more complex folded structures as seen in cores $V-13$ (Figure 4b: arrow 4), $V-15$ (Figure $\mathrm{b}$, arrow 3 ) $V-16$ (Figure $7 \mathrm{~b}$, arrows 1 and $2)=V-17$ (Figure $8 \mathrm{~b}$, arrou 1 ), $V-18$ (Figure $9 \mathrm{~b}$, arrow 2) $V-20$ (Figure 11 b: arrows 2 and 3 ), $V-21$ (Figure $12 b$, arrow 2 ): $V-5 S$ (Figure 16t, arrows 1 and 3 ), and $v-76$ (Figure 17, arrow 2 ) = If an ice keel comes to rest on the bottom. simple loading wili orcur through the pressure exerted by the weight of the ice. The 
resulting structures may be flame structures, ball and pillow structures or dish structures. seen in cores $v-13$ (Figure 4b: arrou 4): $v-15$ (Figure $6 \mathrm{~b}$ : arrow 3) $v-21$ (Figure 12b, arrow 2 ), and $v-55$ (Figure 16b: arrow 1 ). If the gromded ice trel is subsequently moved, then a squeezing of the soft sediment below and away from the keel may ozcur and the result may be simple asymmetrical folds seen in cores $V-16$ (Figure 7 b. arrow 1 and 2 ), $\checkmark-17$ (Figure $8 \mathrm{~b}$, arrow 1 ), $V-19$ (Figure $7 \mathrm{~b}$, arrow 2 ), $\checkmark-20$ (Figure $11 \mathrm{~b}$, arrows 2 and 3 ), $v-21$ (Figure $12 \mathrm{~b}$, arrow 3 ) : $V-55$ (Figure 1 tb: arrow 3 ) and $V-76$ (Fiqure 17. arrow 2 ) pointing away from the bottom of the ice gouge: much like tooth paste squeezed out of a tube (Figure 21). Because the sediments are soft (fine grained and unconsolidated), the tendency for the material to flow is high and the result should be elongation (thickening) of the folds in the hinge area and thinning along the 1 imbs (Billings, 1972). In actual cases of ice qouged sediments, a combination of loading and folding can be seen (Cores V-16 (Figure 7 b. arrous 1,2 , and 3 ), $V-17$ (Figure $B b$, arrow 1 ) $V-19$ (Figure $7 \mathrm{~b}$, arrow 2 ), $V-20$ (Figure $11 \mathrm{~b}$, arrous 2 and 3 ), $V-21$ (Figure $12 \mathrm{~b}$, arrows 2 and 3 ), $V-55$ (Figure $16 \mathrm{~b}$, arrows 1 and 3 ), $v-76$ (Figure 17 , arrow 2 and 3 ).

The cores in this report provide examples of ice deformed sediments, however, the observer is 1 imited to a $12 \mathrm{~cm}$ wide, unoriented eross-section through sediments that are known to be ice gouged. This makes the observation of large scale or continuous structures difficult. Figure 22 is a hypothetical sross-section through ice gouged sediments based on model

considerations and cores. Figure 23 is a sketch of core $v-16$ from this study that might have teen taken from an area not unlike Figure 22 . Figure 24 is a photograph of a wider core taken through ice deformed sediments on the North Sea tidal flats and could also have been taken from an area of geformation modeled in Figure 22 .

\section{ITE-SEDIMENT INTERACTION}

The cores analyzed in this study have offered a unique opportunity to observe the effects of ice sediment distumbance by drift ice on a high latitude shelf environment. The transect of cores intersects zones with different intensity of seabed disruption by ice. This situation has allowed us to observe the deformation of several depositional environments associated with varying degrees of ice-disturbed ocean bottom.

Figure 25 is a map of ise gouge intensity a product of maximum gouge depth maximum gouge width and gouge density per kilometer) in the study area with the locations of the coring sites lafter Barnes et al .: 


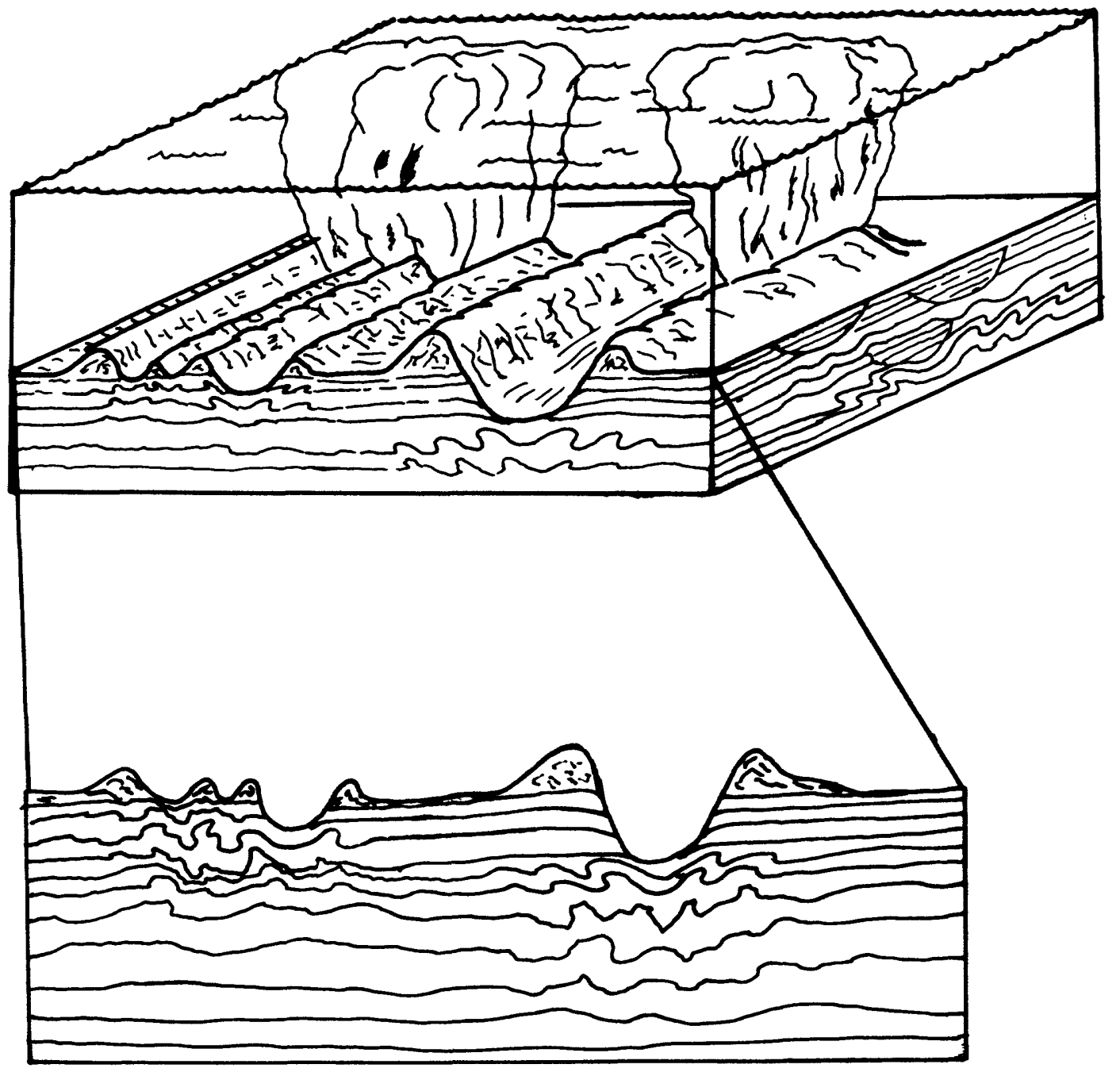

Figure 21. Schematic drawing of ice gouging process and related deformation of sea floor that may occur (modifies after Barnes and Rearic, 1985). It is the author's belief that the sediments below the gouge would tend to flow away from the bottom of the gouge causing asymmetrical folds that are elongate (thickened) in the hinge areas and thin along the limbs, resulting in the apparent lengthening of lamina or bedding. 


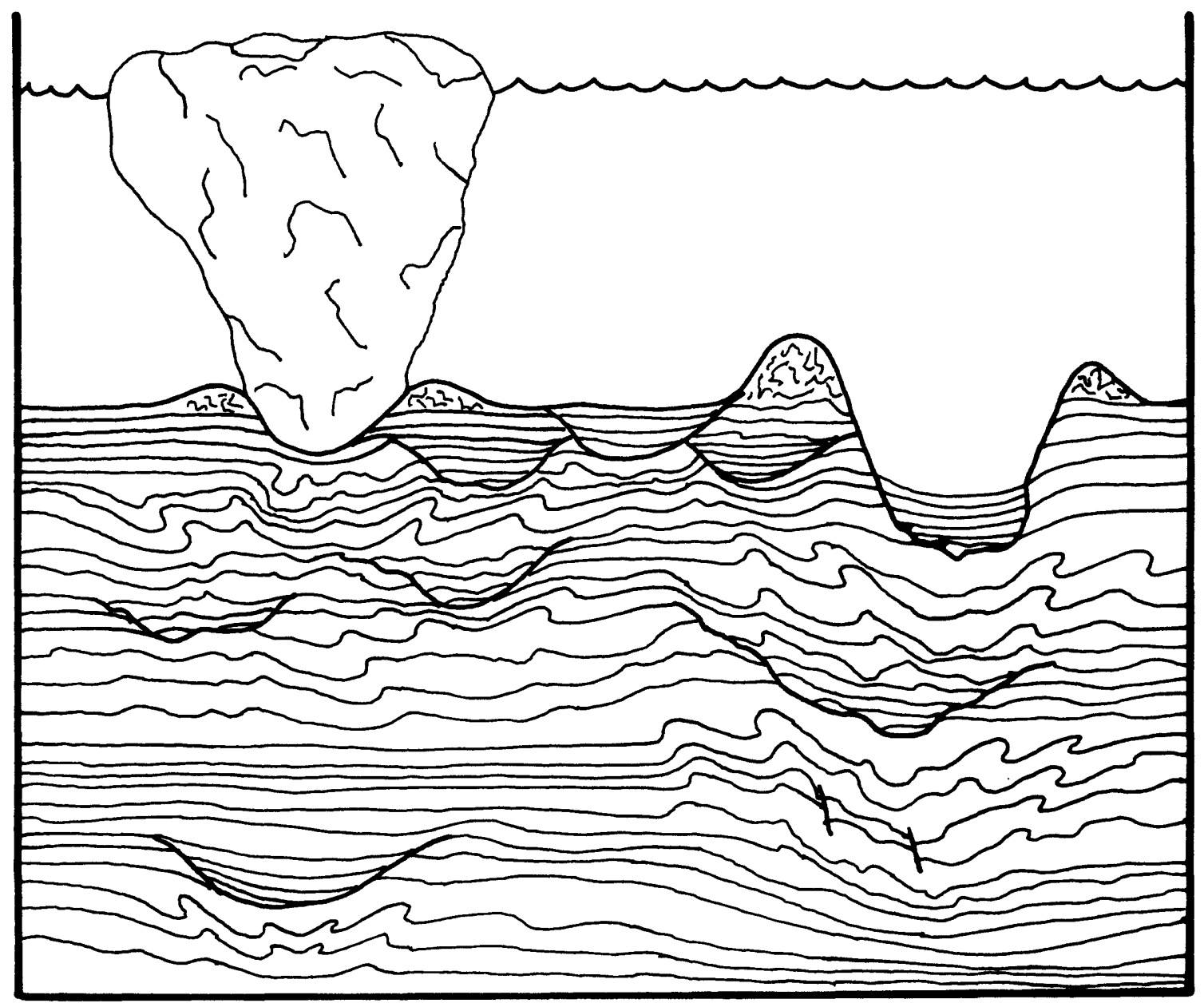

Figure 22. Schematic drawing of hypothetical cross-section through (preserved) ice gouged sediments. Heavy 1 ines in cross-section are preserved gouge troughs. Refer to text for explanation. 


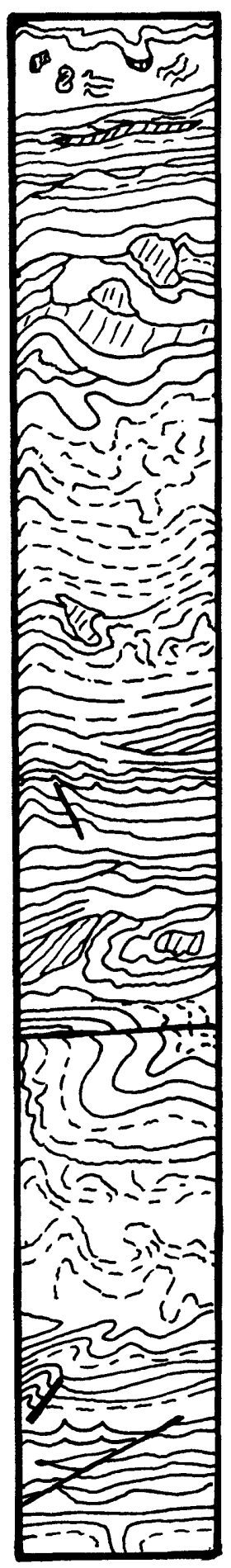

Figure 23. Sketch of core V-16, highlighting deformed zones in core. Compare this Figure with Figure 22 and Figure 24. Note similarity in deformational strucures. 


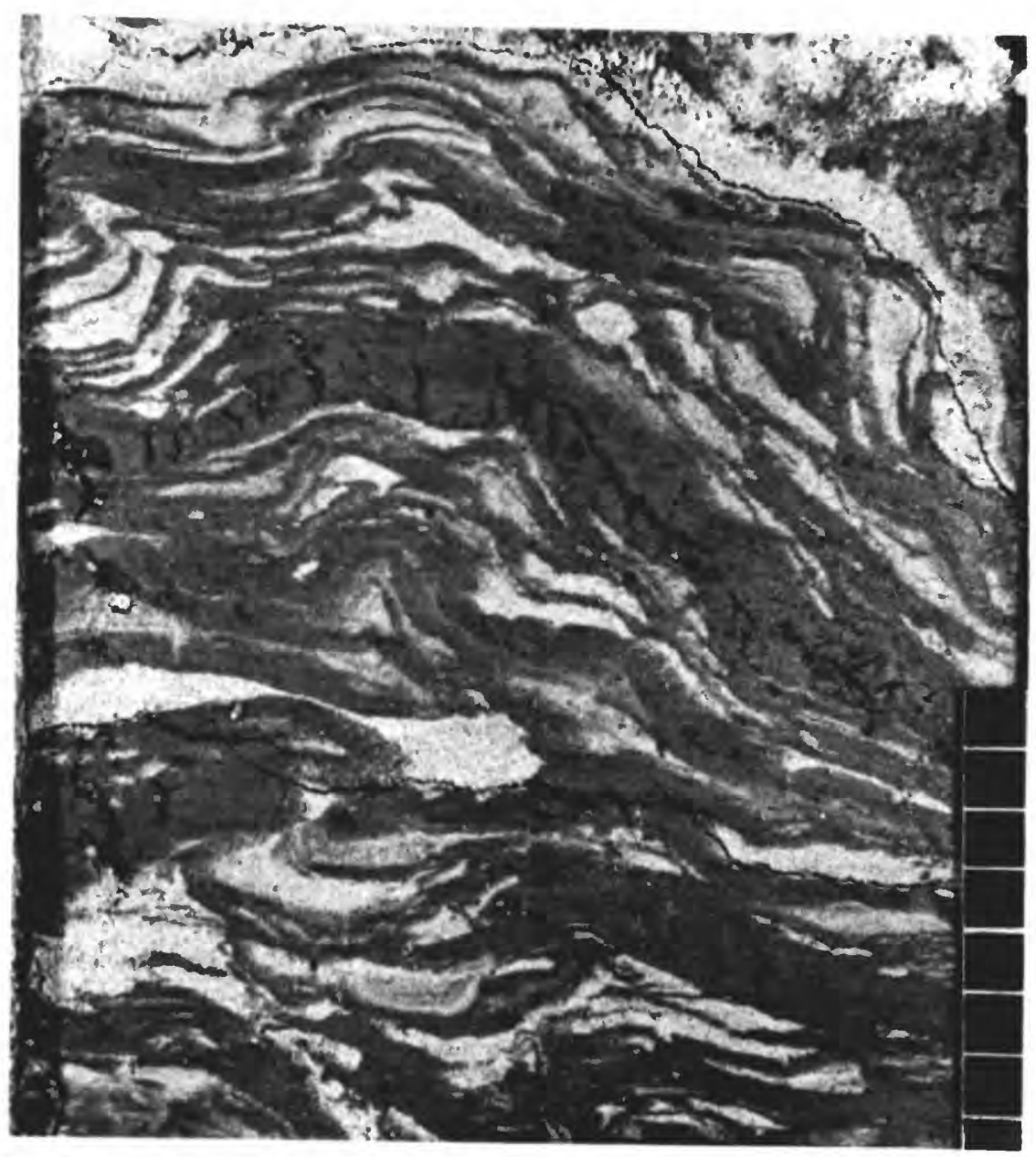

Figure 24. Photograph of ice deformed sediments from North Sea tidal flats. Note similarities to cores from study area. Scale is in centimeters. (Photo from Reineck and Singh, 1980). 


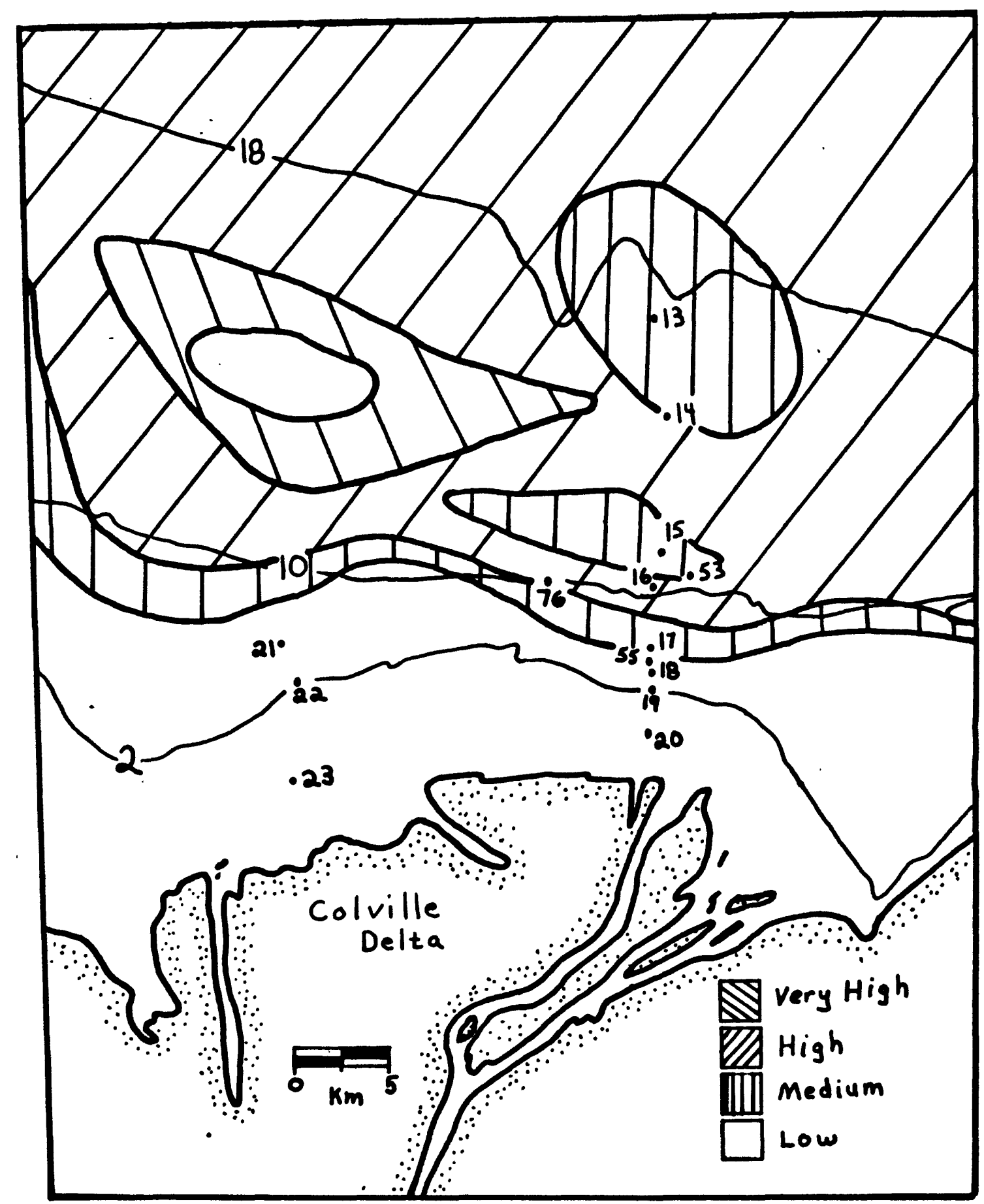

Figure 25 . Ise gouge irtersity map uith coring zosalities overlain (modified after Earnes et al: 1994). Note that core transect srosses severaz different mapped intensities of ize qouging. Fiefer to this fiqure throughout discussion of ire sodimerit interaction. 
1794). It can be seen that gouge intensity is low shoreward of the 10m isobath (Barnes et al., 1984). Offshore of the $10 \mathrm{~m}$ isobath ice qouge intensity quickly increases and varies from mediun to very high (Barnes et al., 1994).

The variability in ice gouge intensity has been related to variability in ice cover (Barnes et al.: 1984). Onshore of the $10 \mathrm{~m}$ isobath is the zone of fast ice; an essentially stationary ice canopy that acts as an extension of the land (Reimnitz et al:z1979). Few winter gouges form in this area as ice movements are rare. At approximately the $10 \mathrm{~m}$ isobath an inshore stamuki zone forms during early winter where the stationary fast ice and the moving pack ice meet (Reimnitz et al., 1978 ; Barnes et al., 1984). Grounded first year pressure ridges develop at this boundary and actively scour the bottom as the pack rotates westward (Fieimnitz et al, 1779; Earnes et al; 1984). Consequently the intensity of ice gouging increases at this boundary (Figure 25). Gouge intensity is variable and derreases slightiy offshore of $10 \mathrm{~m}$ until approximately the $20 \mathrm{~m}$ isobath (Barnes et al.. 1934) where the major stamukhi zone forms (Feimnitz et al $=$ 1978). The grounded ice ridges of this stamukhi zone are believed responsible for the hiqhest ice gouge intensities encounteres on the shelf cearnes et al.. 1784). Intense gouging continues out to approximately the $40 \mathrm{~m}$ isobath and then decreases sharply because fewer ice keels can reach the bottom cBarnes et al.. $1794)$.

Cones $V-13$ and 14 were taken from water depths of $17 \mathrm{~m}$ and $15 \mathrm{~m}$ respectively. Deformation in these cores is concave downmard and is attributed to penetration of the core bariel (Figures 4 b. arrow 3 and 5 b. arrou 2 ). Small scale load features are present (Fiqure 4b. arrou 4) which is this author"s belief result from overpressuring by groundes ice. In general, these cores show little ice-related deformation and this correlates with a decrease in ice gouge intensity in these water depths (Figure 25).

Cores $V-15$ through 17,53 and 55 taken from the 13 $m$ to $7 \mathrm{~m}$ depth range (Fiqure $1 \mathrm{~b}$ ), are believed to display intense deformation caused by ice gouging. contorted and folded bedding, and loaded contacts are dominant. Rip-up slasts (Figures tb, arrow 1. 7b, arrow 3 , eb, arrow 3 ) as well as trumcated and offset bedding (Figures 7 b. arrows 1 and 2 , 8 b. arrow 1 , 16 b arrow 3 ) are present. In general, internal core stratigraphy is obliterated (Figure $7 b$ ). Here the intensity of possible ice related defornation cores corresponds to their position within the inshorg stamukhi zone. The inshore stamukhi zone extends from epproximately the $\mathrm{g}$ is isobath 
to the $12 \mathrm{~m}$ isotath (Barnes et al -1984 ; and cores extracted from this zone display the most intense ice related deformation. $v-55$ shows the smallest degree of deformation (visual estimate is less than $15 \%$ of core) of cores from this area and most likely 1 ies just inshore of the most intense ice turbation.

With the exception of core $v-20$. cores $v-1 s$ through $23=$ all from water deptrs less than 4 m display 1 ittle or no ice gouge related jeformation. Internal Etratigraphy within each core is coherent and consists dominantly of horizontally laminated sands: silts. and muds. These cores were extracted from the area that is covered by the fast ice canopy. It might be expected that 1 ittle or no deformation is present in these cores: because there is lithe or no ice movement for most of the winter (Barnes et al: 1984 ), and any deformation may possibly be relates to ither shoreward ice push during winter, or to grounded ice during spring break-up. A few loaded contacts are present (Figure $9 \mathrm{~b}$. arrow 1 . 11 b. between arrous 1 and $z$; $12 b$, arrow 2 but truncated laninations and bedding are probabiy related to hydraulic processes rather than ice. Core $V-20$ from $1.5 \mathrm{~m}$ of water and only $3 \mathrm{~km}$ from the delta is the anomaly for this group of cores. A box fald is present in the upper hal of the core (Figure $11 \mathrm{~b}$, arrow 2 ) and an overturned fold occurs in the lower half (Figure $11 \mathrm{~b}$. arrow 3). This author believes that these folds rerpesent rare ice reiated jisrutptions.

If ice deformation of primary sedimentary structures occurs in the Beaufort Sea as suggested by my observations: then ancient analogs of ice gouged sediments may be preserved in the stratigraphic record. and should be recognizable on the basis of their Etruttural deformation = Two examples of environments from the literature known to have had floating ice present suggest the presence of ice gouged strata.

\section{GLACIAL LAKE AGASSIZ: AN EXAMPLE OF PRESERVED ICE GOLIGES}

The preserved lake plain of former biacial Lake Agassiz in southern Manitoba. eastern North Dakota. and uestern Minnesota around the Red River Valley displays a lake bej surface morphology that is characteristic of present day sea floor morphology in heavily ice gouged areas of the continental shelf of the north slope of Alaska (Clayton et al : 1965).

Lineations in the Lake Agassiz plain are typically characterized by ridges and troughs averaging $53 \mathrm{~m}$ wide and $2 \mathrm{~m}$ deep (Horberg. 1951) and bear a unique resemblance to ridges and trougts on the sea floor of the north slope of Alaska, where ridges and troughs are 
typically $3 m$ wide and $1 \mathrm{~m}$ deep (Reimnitz and

Barnes, 1974). In both instances, 1 ineations may be as long as several tilometers.

Horberg (1951) was first to observe and

characterize the ridges and troughs on the Lake Agassiz plain. Horberg hypothesized that the ridges were formed by either fracture filling between blocks of lake ice, or as tundra ridges due to grounded ice wedges. Colton (1958) stated that the ridges were the result of frozen ground structures formed during the retreat of the late Wisconsin ice sheet, and based his hypothesis on the occurrence of periglacial involutions, fossil ice wedges, and polygonal and network soil pattenns. ciayton et ai = (1965) reinterpreted the ridges and troughs as being ice-drag marks resulting from the grounding of floating (qlacial) icebergs. Gerhard (1980) also interpreted the ridges to be the result grounded ice. Dredge (1791), Fenton et al = (1993). Mollard (1983), and others have interpmeted the lineations present on the Lake Agassiz plain to be ice-drag features.

Horberg"s earliest observations also documented the oceurrence of deformation below ridges and troughs on the Lake Agassiz plain. His original deseription is as follows:

$$
\text { "Folded lake Elays occur 3-Bft below the }
$$
surface for a distance of about $25 \mathrm{ft}$. Asymmetrical folds with dips up to vertical could be traced from one side of the ditch across its bottom to the other side. The largest fold has a height of at least $6 \mathrm{ft}$. other deformed zones a few hundred feet abay are separated by areas in which the clay appears to be horizontal. At this locality it is difficult to explain the deformation other than by the former presence of grounded ice."

Fenton et al . (1993) documents the presence of preserved cut and fill structures and folds in the deposits of the Lake Agassiz plain. The cut and fill structures are believed to be preserved i ce gouges below the present day surface: and the folds are believed to be a direct result of ice overloading. An outcrop sketch by Fenton et al. (1983) can be seen in Figure 26 . Mollard (1903) presents the orcurrence of large-scale folds and sut and fill structures for his hypothesis for the lineations being caused by ice scour =

The aforementioned surface morphology and structural features from the lake bed of Glacial Lake Agassiz are similar to those reported here from ice gouged sediments on the continental shelf off the North Slope of Alasta. 


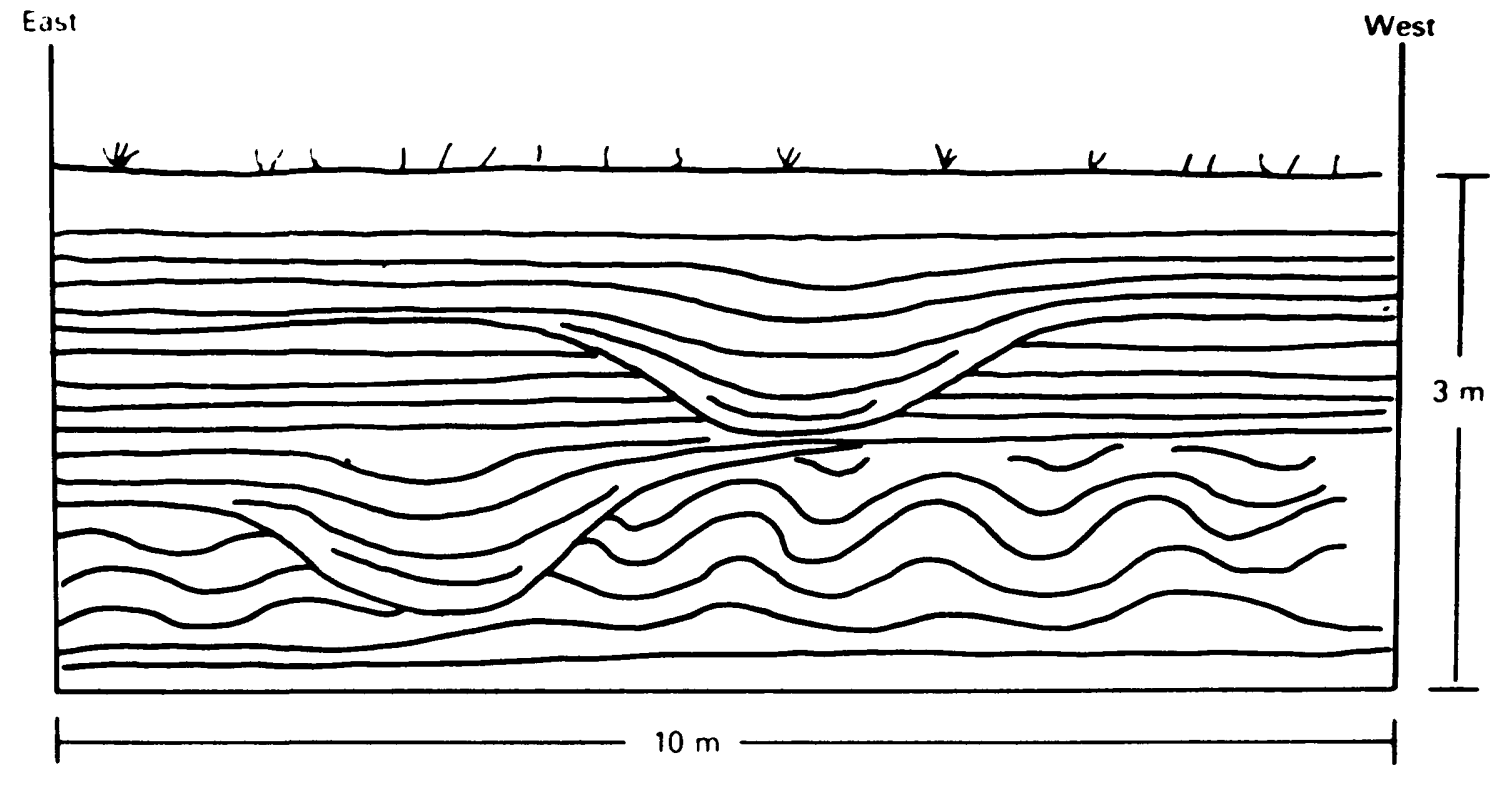

Figure 26. Outcrop sketch of preserved ice gouges and associated deformation from the Lake Agassiz plain. (From Teller and Clayton: eds. Fenton et al, 1983). 
The documented occurrence of asymmetrical folds belou the large cut an fill features on the Lake Agassiz plain by previous researchers supports my hypothesis for the type of deformation that may orcur in the process of ice gouging. The similarities between the Beaufort Shelf surface morphology and core stratigraphy with Lake Agassiz surface morphology and sediments supports the interpretation that the features preserved in the Lake Agassiz plain are paleo ice gouges and that these features may be characterized on the basis of the sedimentary and deformational structures associated with them. The ability to trace lithologic units between ice gouges on the Lake Agassiz plain, in contrast to the lateral discontinuity in the Beaufort Sea. Suggests a lower intensity of ice gouging. or more rapid sedimentation in Lake Agassiz. The lack of preservation of laterally continuous 1 ithologic units in the Beaufort sea may reflect rapid reworking in relation to the rates of sedimentation.

\section{LATE PLEISTOCENE LACISTPINE SEDIMENTS DF THE DNTAFIO}

BASIN, CANADA: AN ALTERNATIVE INTERFRETATION.

Glacial and postglacial sediments exposed in the El iffs along the Scarborough Bluffs at Lake Ontario, Canada consist in part of hummorky and swaley cross-stratified sands contained within a glaciolacustrine complex composed of fine grained sediments (Eyles and Clark. 1986).

The rooks, locally known as the Don Beds represent sediments deposited on the floor of a glacier-dammed lake during early and middle Wisconsin time (Eyles and clark. 1986). The sedimentary structures observed in the local ity are des:ribed as subparallel undulatory eross-strata with low angle terminations and truncations that are either convex-up or concave-up defining a hummock or a swale respectively. The structures appear to be radially symmetrical and have wavelengths up to 4 $\mathrm{m}$ and heights up to $40 \mathrm{~cm}$. Laminations along the top of the hummoley forms are typically truncated and mantled by symmetrical wave ripples and mud drapes. In many cases these bedforms are in erosional contact with similar bedforms above and below. These structures commonly contain ice-rafted dropstones and in some cases are reported to display convoluted and deformed beding (Eyles and Clark, 1986). A typical outcrop and sketich can be seen in figure 27 .

These seposits are interpreted to have formed as a result of sedimentation below storm waves that entrain large volumes of sand. and that hummosks may be very iarge post-vortex ripples uith individual laminations representing pulses of 1 iquefaction. suspension. and sedimentation of sand by a single storm waye or wave 

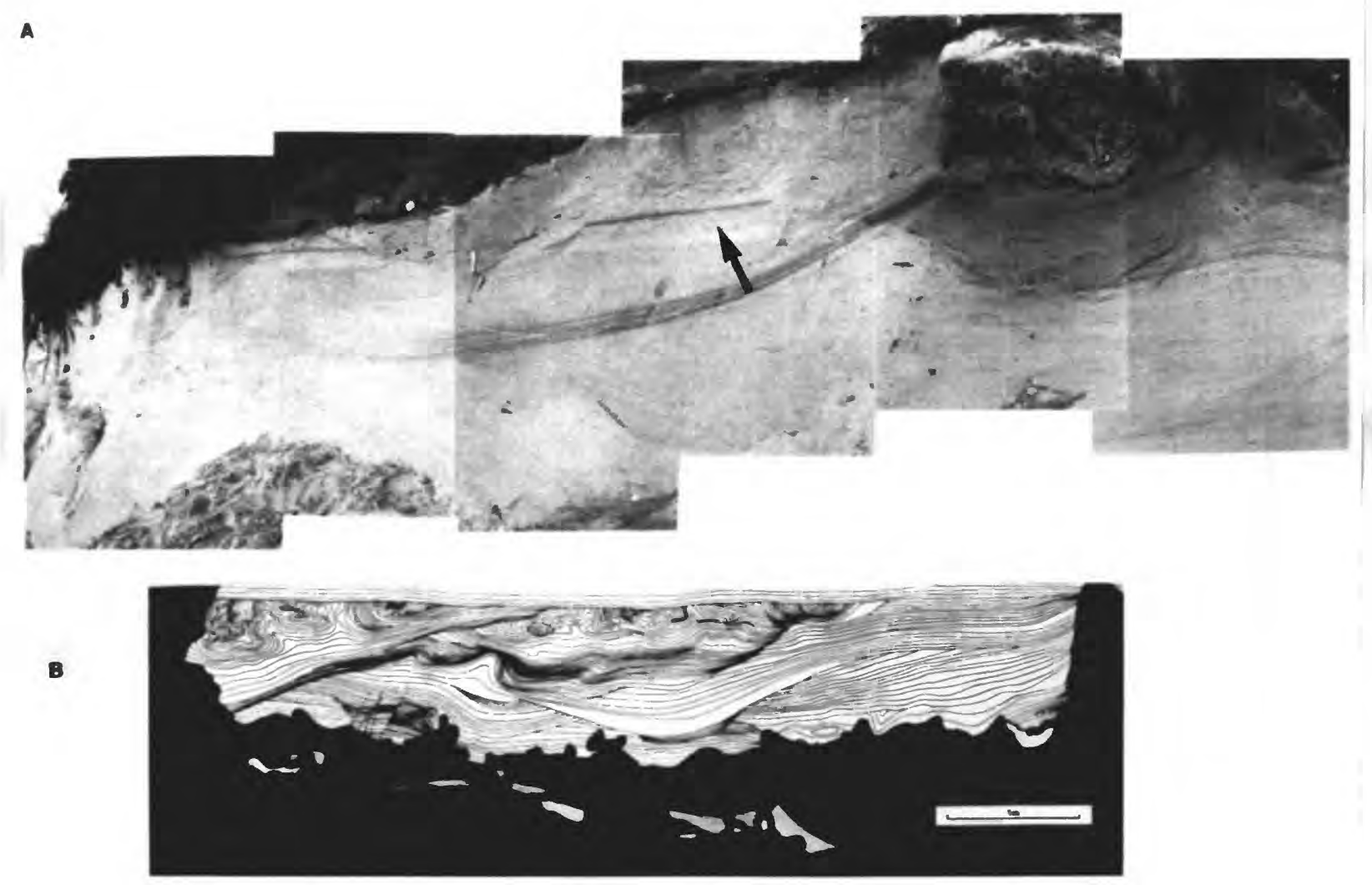

Figure 27. Qutcrop photograph and sketch of believed storm generated bedforms in the Scarborough Bluffs, Ontario. Note the similarity to ice gouged sediments in Lake Agassiz (Figure 26), and compare to hypothetical cross section (Figure 22) and to structures present in cores (figures $6,7,8,9,11,12,16$, and 17). These unusual bedforms may very well be ice gouge related. (From Eyles and Clark, 1986) 
train (Eyles and Elark, 1786). Eyles and clark state that the precise hydrodynamic setting and evolution of such deposits are not fully understood, but believe that they must result from strong oscillatory flows. or at least oscillatory dominant combined flow (Eyles and Ciarl: 1986$)=$

An alternative hypothesis for the development of the hummocky and sualey bedforms present in the Scarborough Bluffs suggests these strustures may in part result from ice quuging. The paleoclimatic setiing at the time of deposition of the units certainly favors the presence of floting ices and is in part confirmed by the presence of dropstones.

The preservation of well defined cut and fill

structures belou which are deformed. laminated sedimentes coupled with the presence of floating ice suggests the origin of these unusual structures could be related to drifting ice kels. It may be that some of these features are derived from storn generated waves. but the loaded nature of underlying contacts and the deformed character of the sediments involvad, as uell as the similarty to bescribed logalities of knom ice gouged sediments (Fenton et $21=1783$ ) , qive strong avidense in favor of ice disupted sadimentation in the area. 


\section{SUMMARY}

The relative intensity of disturbance caused by grounded ice seen in a transect of sediment cores can be directly correlated to patterne of mapped ico gouge intensity in the sane area, and the ice gouge intensity can subsequently be correlated to areas of greatest pressure ridge development.

A hypothetical model based on the sedimentological characteristics of cores in this study has been developed for the deformation assoriated with the ire gouging process. Soft sediment deformation in areas where ice gouging is dominant is believed to range from simple load structures to more complex folded and faulted bedding. This deformation has been depicted schematically in a hypothetical cross-sectional model (Figures 21 and 22 ).

The data gathered in this study have been compared to ancient rocke from areas where floating ice was known to be present. Deformation in sediments documented in the ancient environment correlates to deformation otserved in the modern analog and is believed to fit the hypothetical model.

Furthermore. sediments and structures in the Ontario Easin believed to have been derived from storm generated currents have been compared to cores and observations in this stujy. An alternative interpretation of those sedimentary structures proposed here is that they are the result of sediment disturbance by drifting ice.

\section{CONLLUSIONG}

The sediments investigated in this study have a complex depositional history that has in many cases been overprinted by deformation caused by the process of ice gouging. The fact that ice-sediment interaction plays an important role in the development of deformational structures is evident from the cores analyzed in this study.

1. Ire relatod deformation has been preserved in recent sediments from the study area.

2. Ice related deformation can range from simple load structures to complex foljed and faulted structures.

3. The intensity of ice related deformation can be tentatively correlated with mapped trends in ise gouge intensity.

4. Lithologic: textural, and strutural eriteria 
normally used to elassify sediments to a depositional environment may be entirely obliterated if ice was present during deposition or prior to lithification. Areal extent of one lateraly continuous 1 ithologic unit is probably greatly influenced by the relative intensity of the ice gouging process.

5. Deformational features found in ice gouged sediments are unusual enough to be used as a base eriteria for the identification and interpretation of ancient ice-deformed sediments. and two examples have been used to illustrate and support this arqument.

This has hean a preliminary investiqation: in-depth experiments on the formation of ice reiated deformation, and exhaustive tield work to find more examples in the stratigraphic record have not been condusted. Enphasis in fiture studies should be concentrated on worting laboratory models of ice gouging: and extensive field work should be conducted to ascertain if other examples of preserved ice gouges and the associated deformation exist in the ancient rook record.

\section{AFPENOIX A}

\section{GDE DESTFIPTIONS}

CORE $V-13 \mathrm{~B}$

Core V-138 located at $70^{\prime} 4$ a $^{\prime \prime}$ north latitude. $150^{\circ} 28.1^{\prime \prime}$ west longitude in $19 \mathrm{~m}$ of uater.

o-10 cm is composed of clay, green to green gray, massive, burrous and pelecypod fragments present. Sand interbeds and laminae scattered with contorted contacts. Sand is pink clear and translucent, fine to very fine grained quartz. Hematite (1imonite ?) staining common in sand.

10-10 cm is sand, pink, :lear, and translucent quartz: commonly with Fe oxide stains fine to very fine grained: scattered medium grains and shell fragments. Mud balls common in this units composed of green to gray clay=

$16-19$ cm is sandy tay, gregn to green-gray. pelecypod fragments common. upper and lower contacts deformed.

$19-25 \mathrm{~cm}$ is -1 ay and sand interbeds. Clay is green to green-gray: massive, slightly mottled, sand is fine to very fine grained ciean quartz. Bedding and contacts very irregular and contorted, deformes.

25-39 cm is clay, green to green-gray, sandy in

part with shell fragments commoni massive, upper contact deformed.

39-49 cm is sand, pink, sear and transiucent,

fine to very fine graingd guartz: horizontaliy 
laminated upper and lower contacts deformed. loaded. $49-51 \mathrm{~cm}$ is sandy siay massive. upper and lower contacts teformed.

$51-53 \mathrm{~cm}$ is clay, green to green gray. massive, deformed contacts.

$53-59 \mathrm{~cm}$ is sandy Elay, visibly laminated in upper

$4 \mathrm{~cm}$. laninations 51 ightly deformed; some possibly

truncated 1 ower $2 \mathrm{~cm}$ is massive.

59-61 cn gand lense extending upward at 30 degrees

and in $3 \mathrm{gm}$ into sandy blay, contacts irregular.

61-7t con is sandy ciay, scattered coarse sand

grains and pebbles. rare peleypod fragments. some distorted laninations in upper part, sightly mottled with irregular pozkets of sand or pebbly mud. Lower contact visibly deformed.

$76-87 \mathrm{~cm}$ is composed of interbedded clay and sandy Elay laminations well defined; and in places highly deformed very tight reambent fold in the misdle of this section. deformation may be a result of coring disturbance.

CORE $V-14$

Core V-14 located at $70^{*} 41.5 "$ north latitude: $150^{\circ} 27.2^{\prime \prime}$ west 1 ongltude in $15 \mathrm{~m}$ of water.

$0-9.5 \mathrm{~cm}$ is composed of silty sandy Elay, slightly

mottled. no distinet bedding. brown to brownish-gray =

9.5-11.5 cm is composed of sand. fine to very fine

graingd with abundant peleypod fragments and pebbles.

Upper and lower contacts deformed. (loaded ?).

$11.5-63.5 \mathrm{~cm}$ is composed of elay, dark to drab

green: and brown. silty in spots but with random

orientation massive in core and peel, faint bedding and

laminations visible in radiograph. highly deformed in

spots. some actual offset observed in laminations on

radiograph. Silight edge deformation due to coring.

overall character of core is coarsening upward.

CORE $v-15$

Core V-15 located at $70^{\prime} 37^{\prime \prime}$ north latitude : $150^{\prime} 27^{\prime \prime}$

west longltude in $12.4 \mathrm{~m}$ of water.

$0-7 \mathrm{~cm}$ is composed of sand, fine to very fine

grained with silty matrix, no visible bedding in core or peel, but large burrou evident on radiograph from 0 to 4 cm. Burrow has gleaner sand of same grain size. Sand is relatively homogeneous with oleaner sand in lower part. Lower contact is highly deformed.

9-14 $\mathrm{mm}$ is elay gray to green. massive very sandy

in part (potkets?) . Upper and lower contacts deformed.

$14-19.5 \mathrm{zm}$ is sand, fine to very fine qrained.

silty matrix. Iaminated, gal th some laminations truncated 
iust below upper contact.

massive.

$19.5-20.5 \mathrm{~cm}$ is a lense of alay, green to gray and

$20.5-23.5 \mathrm{~cm}$ is sand. fine grained and admixed with sandy :lay, moderateiy well laminatedy some shell fragments present. upper contact with alay lens is highly deformed (loaded), lower contact only moderately deformed.

massive.

$23.5-25 \mathrm{~cm}$ is a lens of $\mathrm{clay}$. green to gray:

$25-29.5 \mathrm{~cm}$ is sandy clay, gray to qreenish. some 1 aminations visibie on radiograph near top contact, moderately deformed. Shell fragments visible on radiograph and in core.

$27.5-31 \mathrm{~cm}$ is sand: very fine grained, silty matrix: upper and lower contacts highly deformed.

31-41 ca is clay, gray to green. massive, some laminations evident in lower part, all laninations are deformed giving a distinet mottled appearance on the radiograph, laminations not visible on core, but are faint on peel.

41-44.5 cm is sand, fine to very fine grained. moderately mell laninated. possible ripple eross 1 aminations in upper part. Upper contast also deformed.

$44.5-46.5 \mathrm{~cm}$ is sandy clay, gray to greenish. grading into sand in lower part.

$46.5-50$ en is sand. fine to very fine grained. sily in top part grading into elean sand in bottom: steep angular cross 1 aminations are truncated at upper contact. Large biock of moderately clean sand is apparent on radiograph. however the same area appears only deformed on peel. Laminations in block are horizontal.

50-51.5 tm is blays green to greenish gray: massive upper and lower contacts highly deformed.

$51.5-55.5 \mathrm{~cm}$ is sand and sandy biay olay potkets present: highly irregular and deformed upper and lower contaits.

$55.5-62.5 \mathrm{~cm}$ is -1 ay and sandy $=1 \mathrm{ay}$, green to gray and dark gray, massive exept where very sandy two $1 \times 4 \mathrm{~cm}$ blocks of sandy clay are $v i s i b l e$ on the radiograph in the middle of this section. Blocks are well 1 aminated and rest fogether with great angular discontiruity: upper contact highly deformed. lower contact slightly deformed.

$62.5-77.5 \mathrm{~cm}$ is sand and sandy 1 ay s sand is very clean, dark gray and appears to be tightly folded very fine grained. The sandy clay octupies the inside of the fold. The sand also contains scattered pebbles and shell fragments.

$77.5-97.5 \mathrm{in}$ is composed of highiy deformed sandy 
clay and sil to gray to dark grays sand is very fine grained. Some Eandy pockets. Deformation appears to be the result of core removal.

CORE $V-16$

Core v-16 located at $70^{3} 3$. $^{\prime \prime}$ north 1 atitude. $150^{\circ} 28.2$ " west iongitude in $11.5 \mathrm{~m}$ of uater. 0-5 cm is clay, dark green to drab, massive in core, some beding in peel, appears mottled on radiograph. Sandy in part uith sand occurring in small porkets.

5-47 on is tiay, sandy blay and sand laminae. Clay is darti green to brown massive in core and peel.

laminated in rajiograph. Sandy clay is green to gray in core. gray in peel, massive in core, some structure is evident in peel. laminated in radiograph. Sand is fine to very fine grained quartz with silty matrix massive in core. 1 aminated in peel and radiograph. This portion of core is extremely disrupted and deformed.

Deformation is best explained by coring effects sinise much of the greatest deformation oceurs at core edge. 47-50 cm is sand, brown to gray, fine to very fine grained, laminated: deformed. $50-62 \mathrm{~cm}$ is clay and sandy clay. Clay is dark green to broun and gray mottied in core and peal. Ianinated and deformed in radiograph. Sandy clay is green to gray in core and peel, laminated in core and peel. laminated and deformed in radiograph. Upper and lower contacts of this unit are deformed. $62-97.5 \mathrm{~cm}$ is composed of 61 ay and sandy elay with sand pockets. Clay is green to gray massive in core. laminated in peel and rasiograpti. Sandy clay is light to dart gray massive in core laminated in peel and radiograph. This section of core is extremely deformed. Some small scale folds exist as well as numerous shear planes and of fset laminations. Folds and offset ane best visualized on radiograph. Deformation is probably not coring related as some overlying units are relatively undeformed.

CORE $v-17$

Core $v-17$ logated at $70^{\prime} 34:$ north latitude. $150^{\circ} 28.2^{\prime \prime}$ west longitude in $0.5 \mathrm{~m}$ of water.

0-10 cm is clays dark green. massive in core. but sightly silty in part: vertical structure visible in radiograph may be a reili burrow or some type of coning disturbance.

$10-10.5 \mathrm{sm}$ is $\exists$ lens of 1 ight gray fine grained sand, appeare to te the terminating point of vertical structure mentioned above. 
$10.5-20.5$ en is alay darti green, massives with very fine grained laminated silty sand pockets. Laminations in sand pockets are deformed.

$20.5-23.5 \mathrm{~cm}$ is lay dark green. massive s some contorted laminations visible on radiograph.

$23.5-24 \mathrm{~cm}$ is sand.1 ight gray very fine grained. Eilty, deformed.

24-40.5 cm is clay, dart green, massive in core and peel: highly deformed in radiograph sandy in part. scattered pelecypod and gastropod shell fragments.

$40.5-47.5$ cn is clay and sandy clay. Clay is green to qrays faint tedding in core and peel, teformed in radiograph. Sandy olay is gray, laminated in core and peel " highly deformes in radiograph. This unit grades down into sand and liay interbeds.

$47.5-62.5, \mathrm{~m}$ is sand and 01 ay interbeds. Sand is gray, fine to very fine grained, iaminated. clay is green to gray mostiy massive but mottied in part. This unit has a tighiy nothed appearance due to the highly contorted nature of the sand/clay lamination contacts.

Some deformed lenses of sand are also present.

62.5-67.5 cm is sand. qray, very fine grained.

siltys deformed.

$67.5-74.5$ in is $512 y$, dark green to gray, massive

to hor zontally laminated some contacts deformed.

$74.5-79.5 \mathrm{~cm}$ is sand. fine to very fine grained, very silty matrix, laminated. Two small biocks of this material rest inside this unit with an angular discontinuity of laminations. and appear to be blocky intraciasts or rip up clasts. de formed.

$79.5-92.5 \mathrm{~cm}$ is clay, green, faintly laminated,

82.5-84.5 ta is interbedded very fine sand and silt, and lay. Laminations in this thit are deformed and sheared. and offset is apparent on radiograph. contats highly deformed.

$94.5-95.5 \mathrm{~cm}$ is composed of interbedded clay and sandy slay. Appears massive in core some bedding in peel: Laminated and deformed on radiograph. Small folds and shear plane with of tset are visible in bottom of core on radiograph.

CORE $V-19$

Core $v-18$ located at $7033.2^{\prime \prime}$ north latitude: $150^{\circ} 27.9^{\prime \prime}$ west 1 ongitude in $3.3 \mathrm{~m}$ of mater.

o-17 cm is composed of sand and -lay interbess.

The sand is gray, fine to very fine grained partially oxidizeds horizontaliy laminated. The elay is mediun to 1 ight gray silty in part. horizontally laminated.

Sight edge deformation due to coring. $17-10$ an is blay gray massive in core: laminated 
in peel and radiograph. upper contact deformed. $18-22$ is is clay sandy clay and sand intertods.

Sand end clay as above horizontally laminated.

$22-23$ cm is sand, gray = very fine grained. ripple

cross lamination which are truncated at upper contact.

$23-25 \mathrm{~cm}$ is clays greenish grays massive.

$25-24.5 \mathrm{~cm}$ is sand and organic interbeds. Sand is

gray, fine to very fine grained, lenticular with

iaminations truncated against edge of organics.

organics a light to dark brown and black, fibrous plant material and detritus. lensoidal.

$26.5-28.5 \mathrm{~cm}$ is sand gray to 1 ight qrays fine to

very fine grained, silty horizontally laminated with

some laminations approaching crossbedding. erosional

upper contact with unit above. markedly angular.

$29.5-32$ cm is sand and organi: (peat) interbeds.

Sand is as above but truncates horizontally laminated

organics. Organics consists of partially oxidized

compacted fibrous plant debris.

32-40.5 cm is horizontally laminated sands clays

and organit interbeds. The sand is grays fine to very

fine grained. disseminated organi component to grains. silty in part, hou izontaly laminated. Clay is green to

gray faintly laminates. rich in organics some wholly

organis 1 aninae.

$40.5-41 \mathrm{sm} i \equiv$ peats horizontally laminated with

Elightly deformed lower contact.

41-41.3 ch is Elean sand very fine grained.

horizontally laninated.

$41.3-43.3$ ch is peat green to dark brown and

black some coal possible, horizontally laminated.

highly deformed lower contast.

$43.3-50$ cn is clay uth minor sand and organic

interbeds. Elay is green to gray massive in core.

faintly laminated in peel and radiograpt. organic

content of clay is high $(25-30 \%)$ and is very visible on

ratiograph.

50-51 cm is sand: gray fine to very fine grained: sily ripple cross laminated. Cross laninations are truncated along upper contact.

$51-55$ cn is sand. 1 ight gray, fine to very fine

grained: silty matrix, horizontally laminated with

abundant organics. Organi 1 aminations truncated by

sand body.

$55-56 \mathrm{~cm}$ is clay greenish gray, massive grading

downard into sandy say and clay.

$56-59 \mathrm{~km}$ is c1ay and sandy lay with minor

interbaded organics and sand pods. Ciay and sandy clay

is green to gray, slightly mottied, horizontally

Iaminated. Emall organic component. Small sand pods are

fine graines: Silty; well laminated, and shou up on

ratiograpt $\equiv$ sell laminated blotks and anguler chunks 
suspended in the slay.

$59-77 \mathrm{~cm}$ is elay dark green to gray massive in core: well laminated on radiograph. Some lamination contacts show minor deformation (loading?, minor organic component.

$77-78 \mathrm{~cm}$ is peat, green to brown and black= some coal possible: compacteds thell lanirated.

$78-111 \mathrm{~cm}$ is alay and sandy clay. Clay is green to gueen gray, massive in core and radiograph. ninor organic component. appears highly bioturbated on radiogreph but no burrows can be discenned. Clay grades dombard into sandy clay. Sandy clay is gray. massive: also appears bioturbated. but no burrows evident. Sandy clay in this unit grades to sayey sand along it's bottom contact. obvious overall fining upuara sequence.

111-112.5 cm is rlay. greenish gray, massive: deformed upper and lower contacts.

$112.5-119.5 \mathrm{~cm}$ is sand: gray, fine grained: silt and Elay matrix, high organit content massive.

$119.5-166 \mathrm{~cm}$ is composed dominantly of slay with

one large structure in i composed of sand and organics. The sand is gray f fine grained and interbedded with compacted fibrous plant debris igrasses?. The structure forms a partial fold uith the leminations being vertical in relation to the core at the top of the structure, and tapering of to about 30 degrees in the bottom part of the structure. This structure is suspended in a body of elay and has no similar 1 ithologies above or below it. The clay surrounding this structure is giegn to gray massive in core and radiograph, but has a high organic content that appears to be rootlets of grasses and plant stems. The organias incorporated into the clay do not form any crude besting but do: however = appear to be in growth position. There is also no evidence of tioturbation in this section. but it is highly suspect.

COFE $V-20$

Core v-20 logated at $70^{*} 31.4^{4}$ north latitude: 150.27 .5 " west longitude in 1.5 m of water.

$0-9.5 \mathrm{~cm}$ is composed of sand broun to dark brown. oxidized: fine to very fine grained, horizontaliy moderate to well 1 aminated.

$9.5-10.5 \mathrm{~cm}$ is sand, medium to dark brown fine to very fine graineds interbedded with fibrous organie matter. ripple cross laminated with cross 1 aminations truncated along upper contact.

$10.5-15 \mathrm{~cm}$ is sand tark gray to brown f fine grained, silty interbedded with organic debris and coal o horizontally laminated. organit matter is a 
somponent grain in the sand.

$15-26 \mathrm{~cm}$ is sand olay and organic interbeds. The sand is light gray, fine grained, has a silt and clay matrix horizontally laminated. Clay is green to gray. massive in core, faintly laminated in peel, well lamineted in radiograph. The organi 1 aminae are dark brom to blacks well laminated fibrous organic matter. $26-40.5 \mathrm{~cm} i \leq$ sandy clay interbedded with organics. The sandy clay is gray, with fine to very fine sand, well laminated with dart broun fibrous organic interbeds. This section of cone is highiy deformed into a box fold like structure. The structure is most visible on the peel = but does show up on the radiograph. The structure is concave up and is most likely not the result of coring.

$40.5-47.5 \mathrm{~cm}$ is 5 ay and orqanit interbeds.

Drgani: interbeds in this section are large and average 1 en in thickness. are brown and have a large coal component. All laminae in this section are affected by deformation in unit above, and show a concave up struture.

$47.5-59.5 \mathrm{~cm}$ is sand. gray to brown fine to very fine grained: some organic component and interbeds. highiy deformed laminations. $59.5-70.5 \mathrm{~cm}$ is of sand and $=1$ ay interbeds. The sand and biay is as ahove. but the interbeds are highly deformes into a struture that resembles a recumbent fold. The fold is truncated along a shear plane just upuards of its axis. and holds a great resemblance to a thrust plane. This struture is extremely well defined in both the peel and radiograph. $70.5-37.5 \mathrm{~cm}$ is send gray to brown. fine to very fine grained. massive uith a distinet mottled appearance on core, peel and watiograph. This section shows many irregular trunceted planes and appears highly deformed. although no consistent lamination pianes are present. $87.5-122.5 \mathrm{~cm} i 5$ composed of sand sandy clay and sil and organic interbeds. The sand and sandy clay oceupy the upper $3 \mathrm{~cm}$ of this unit and are medium to light gray with very fine grained sand. moderately laminated with lithe deformation. This sandy clay grades down into silt, green to gray, and brown, with darl broun fibrous organic interbeds. This unit is. moderately well laminated and shows no deformation other than edge effect due to coring. Several sets of asymetrical ripple marks with eross lamination exist with the cross laminations on all sets being truncated along their upper contact. 
$151^{\circ}$. 1" west longitue in 4 n of water.

o-1 in is composed of clay, light gray massive.

i-3e cm is sands i ight brown to grays fine to very

fine grained: sily matrix, well laminated, highly deformed, scattered rlayballs. This unit is highly deformed: with a structure resembing a large fol of in the top $15 \mathrm{~cm}$. Laminetions around tiay bodies shou evidence of flow: miror folds throughout unit. Faint vertical burpou can be seen on radiograph.

$36-37 \mathrm{~cm}$ is tizy: gray. massive.

$37-39 \mathrm{~cm}$ is sand: mediun gray, fine grained with silty matrix: uell iaminated, silghtly deformed.

$39-41 \mathrm{in} i \equiv$ clay, sand, and organics. Clay and send as above: organics are 1 ight hrown to brown and blark, some coal evident. well laninated.

$41-68 \mathrm{~cm}$ is $=13 y$ q queen to gray massive partia11y mottled on radiograph.

so-70 ch is sand. gray. fine to vary fine grained: poonly laninated. highly deforned upper and lower contacts (1oaded?).

$70-72$ cm is clay gregnish qray. mostly massive with some mottled texture in radiograph.

$72-77$ sm is sared fine grained. Silty matrix : some lamination apparent on radiograph, highly daformed lower contaxt.

77-9.3 in is rlay and sand interbeds. Clay is quay to green.erid massive. Sand is gray, fine grained. very silty, faintiy laminated. 1 ensoldal.

e3-91.5 cm is clay, green to qray massive uith

some sandy poikets.

$91.5-72.5$ sm is sand, gray fine grained. 5i1ty, faintly laminated upper and lower contats slightly deformed.

$72.3-93.5 \mathrm{~cm}$ is c1ay gray, massive.

$93.5-96 \mathrm{~cm}$ is $93 n d=$ gray to brown. fine to very

fine graines. 5ilty fantly laminated. lensoldal.

9a-1iz cm is clay, gray partially laminated in

upper and lower part. mottled to massive in remainder. Upper and lower contacts slightly deformed.

$117-117 \mathrm{~cm}$ is sand. qray, fine qrained. $5 i 1 \mathrm{ty}$. nassive upper and lower contacts deformed, with lower contact highly deformed.

$119-121 \mathrm{~cm}$ is clays gray to grean: massive. Lpper

contact highly deformed. lower contact undeformed. massive.

$$
121-122 \mathrm{~cm} \text { is sand. grays fine grained. silty. }
$$

$122-137 \mathrm{~cm}$ is -1 ay greenish gray mostly massive but has some evidence of faint laminations in upper and lower part on radiograpt. some ninor shell fragments. $137-140$ cn is sand. gray, fine to very fine grained, Eily in part: uel1 laminated, highy deformed: may be partialiy folded. 
$140-155$ sm is siay green to gray massive s some evidence of faint laminatione on radiograph. highly deformed upper and louer contacts.

$155-157 \mathrm{~cm}$ is blay with abundant organics. Clay is gray and massive. organiss are disseminated peat and plant stems or small twige?

$157-177 \mathrm{~cm}$ is composed of ciay las abovel uith small orgenic rich pockets and interbeds. Moderately laminated gy th some deformation along lamination contacts.

\section{CORE $V-22$}

Core $V-22$ 10ated at $70: 32.5$ north latitude. 150.59 .6 west $10 n g$ tude in $.6 \mathrm{~m}$ of water.

o-12 cn is composed of silty sand. mediun to light gray fine to very tine grained. scattered shell fragments and mudballs faintly laminated.

$12-87$ in is Eand with intermixed organics. The

sand is brown to dark gray, fine to very fine grained. very silty. high organic component as grains teoalis, well 1 aminated highly deformed. organie interbeds are very fine fibrous piant debris. compacted, weil

laminated. deformet. This unit shows an unusual structure in its middie. The structure is composed of steeply dipping laminations dipping in different directions about a central axis. Near the central axis the laminations dip less and approach horizontal. Several ripple cioss lanination sets are prevalent in this unt, and are subsequently deformed by this struture. Below this strutture is undeformed horizontal iaminations.

a7-80 con is blay green. massives with some shell fragments.

Bs-9e on is sand, trown to gray, fine to very fine grained, sily, small orqani: component horizontally 1 am inated.

$78-114$ zn is sand and clay inferbeds. The sand is broumish gray, fine grained, silty, faintiy laminated, deformed. The clay is gray generally massive but with some faint lamination laminated in radiograph.

$114-170 \mathrm{~cm}$ is composed of sand, interbeds. The sand is gray to brown. fine to very fine grained: very 51 ity in part, horizontaly moderately to bell laminated. high organie component to grains: several sets of ripple cross lamination apparent. The clay i gray massive uith a moderate organic component. The organics aro weli laminated highly abraded plant debris and coal, including tuigs. grasses: plant stems. and peat. one organic pich lamination contains a tuig 1 En in diameter. A vertical burpow 45 cm long is present in this unit and Ean easily be seen on the radiograph as 
weil as the peel. The burrow has saused littie to no disturbance of the laminations that it penetrates.

COFE $V-23$

Core V-23 10 ated at $70^{\prime} 29.5 "$ north latitude. 150.59 .5 west $10 n g i t u d e$ in 1 m of water.

o-4 cm is composed of sand. brown to gray fine to

very fine graineds sity horizontaly laminated.

$4-7$ th is blay, green. massive.

7-9 cm is sand gray, glean oxidized. fine

grained, horizontaly laninated.

e-10.5 sm is clay, greenish gray, faintly

laminated. some fine send 1 aninations.

$10.5-15.5 \mathrm{ch}$ is sand, brown to greys fine to very

fine graineds silty horizontally laminated with

undulating rontacts.

$15.5-34.5 \mathrm{~cm}$ is $13 y$ and organit intarbeds. The

clay is greenish gray and nassive. The organics are

brown to black very fine, fibrous, horizontally

I aminated.

$34.5-44.5 \mathrm{~cm}$ is sand. medium to fine qrained: mottied. bioturbatedz: faintly deformed iamirae.

$44.5-49.5 \mathrm{~cm} i \equiv$ zay and sand interbeds. Clay as

above, sand is gray fine qrained, silty, laminated.

$48.5-51.5 \mathrm{~m}$ is Elay and organie intarbeds. Clay

as above, organics are thin fibrus laminae of plant

detritus.

$51.5-52$ an is sand, gray, fine graines. silty:

ripple crose laminated to horizontally laminated.

52-57 cm is clay organizs, and minor sand laminae =

clay, sand and organics as above horizontally

laminated.

$57-61 \mathrm{~cm}$ is sand: gray, fine grained, silty:

several ripple cross laminated set with 1 aninations

truncated along top contacts of individual sets. Appear

almost as ilimbing ripple marks.

b1-73 cm is Elay greenish gray massive to

horizontally laminated minor organi: component.

$73-74.5$ on is sand, gray, fine grained, silty. massive.

$74.5-96.5 \mathrm{~cm}$ is sand and organit 1 aninae. The sand $i \equiv$ gray, fine grained silty weli iaminated. The orqaniz matter is composed of broun fibrous plant detritus: rootlets: stems and tuigs. This unit is dominantly ripple eross iaminated with the cross laminations reflected in the organics as anell as the sand. Most of the cross lamination sets are truncated along the upper contacts. The bot tom most $5 \mathrm{~cm}$ of this unit is horizontaliy laninated.

$76.5-144$ in is composed of ilay and organit interbeds and 1 aminations, with minor sand laminations. 
The sand s sy and organics are as above but this unit is dominantly horizontally laninated. Some ripple cross lamination does gour in the small sand bodies and in some of the organics.

CORE $V-53$

Cone y-53 10 oted at $70^{*} 36.67^{\prime \prime}$ north latitude, $150^{2} 24.8^{\prime \prime}$ west 1 ongitude in $13 \mathrm{~m}$ of water.

o-t. $5 \mathrm{~cm}$ is composed of alay greenish gray, highy mottled, bioturbated? some shell fragments and pebbles.

$6.5-19.5 \mathrm{~cm}$ is sand. gray, fine grained, well

laminated with abundant shell fragments in lower part. upper contact deformed.

$19.5-21.5$ gn is alay green gray massive with

distorted (loaded?) lower contact.

$21.5-20$ on is sand. gray, fine grained. 5i1ty.

oxidized in part, horizontaliy laminated.

20-73 cm is elay to sandy clay, mostly massive : but where sandy shous 1 aminations. Some ripple cross

lamination present, hithly deformed in part; some shell (pelecypod) fragnents present.

73-94 cm is composed of sand and clay. The sand is gray, fine to very fine grained, silty = lamineted. highly deformed. The clay is greenish gray, sandy in part laminated. deformed. This unit displays a highly deformed structure in its egnter. The structure is composed of sand and shows the flow features around its boundaries and in the clay. This bas most likely

produced by coming.

CORE $V-55$

Core V-55 located at $70^{\circ} 33^{3} .80^{*}$ north latitude:

150.28 " west longitude in $7 \mathrm{~m}$ of water.

o-10 in is composed of Elay, greenish gray, massive to mottleds deformed.

Next is 3 em of sand. gray, fine to very fine grained, silty to blayeys laminated.

10-16 cm is liay, greenish gray massive to faintly laminated. slightly deformed.

$16-24 \mathrm{~km}$ is sand: medium to light grays fine to very fine grained, silty horizontally laminateds lower contast highly deformed.

$24-47$ cm is lays gray massive to mottled: some parts faintly laminateds biaturbated: slightly deformet.

$49-50 \mathrm{~cm}$ i 5 and gray fine to very fine grained. silty horizontaliy iaminated. lensoidal.

50-84 on is Elay, green gray, maseive to faintiy iaminated. bioturbatedz: Highiy deformed in louer part 
of unt with some folding evident.

84-80.5 ch of sandy tiay and organit interbeds.

The biay is gray and massive. The organics are brown

to brown-biaks fine qrained fibrous plant detritus and

peat. This unit shows some moderate deformation.

8a.5-124.5 cn is ciay green gray massive to

mottled and faintiy iaminatad, bioturbated?s some minor

interbeds ant pockets of fine sand deformed.

$124.5-154.5 \mathrm{~cm}$ is sand and blay interbeds. The

sand is bromish gray. fine grained, silty laminated. slightly deformet. The llay is grem gray, massive to

faintly laminated, slightly deformed.

\section{CORE $V-7 \%$}

Core v-76 located at $70: 37:$ north latitude:

$150^{\circ} 34 . \mathrm{s}^{*}$ west longituie in $10.7 \mathrm{~m}$ of uater.

$0-55 \mathrm{~cm}$ is composed of sand. grays medium to fine

graneds silty in parts well laminated. deformed. This

unit shous a great deal of deformation. The upper

portion of this unit displays a dominant concave up

moderate deformation. The lower portion of this section

displays stepely dipping to partialiy folded laminations whith show some evidence of flon along lamination

interfaces, highly deformed. The two different types

of deformation are distinctiy different and the ipuer

set of deformed leminations is truncated at the top by

the upper set.

$55-66 \mathrm{~cm}$ is $-12 y=$ gray to gray-blacto partialiy

oxidizeds highly mottled, with abundant pelecypod

fragments and some complete hal shells.

se-71.5 un i Sand gray fine grained. very silty.

hor zontaliy well laminated to deformed well laminated.

The upper portion of this unit is composed of

horizontally well laminated silty sand. The lower

portion of this unt is composed of horizontelly well

laminated sand that has been deformed into a concave up

low amplitude fold. The laminetions along the upper

contact in the lower part are truncated and the contact

s visibiy dipping. Everything above the contact is

horizontaly well 1 aminated and undeformes. A large

Elay biozk containing organics $3 \times 3$ cm sits dire:tly on

the contact between the two parts of this unit.

$91.5-96.5$ sm of tay gray to gray-black, highly

mottled with a large gastropod sheli visible in the radiograpts bioturbated.

$70.5-112.5$ in is sand gray fine grained. silty.

massive deformed lower contato some snall mud

potsets.

$112.5-115$ cm is alay gray to gray-black faintly

Iaminated. deformed upper and lower contacts.

$115-123.5 \mathrm{~cm}$ is sand. gray, fine grained, silyo 
laninated, deformed upper and lower sontacts. $123.5-137$ on is composed of clay gray to gray-blatk, massive to fantiy laminated with several ripple cross laminates fine grained silty sand stringers, slightly defomed. 


\section{REFERENCES}

Barnes, P.W., Rearic, D.M., and Reimnitz, E., 1984, Ice Gouge Characteristics and Processes: in The Al askan Beaufort Sea: Ecosystems and Environments. Barnes, P.W., Schell, D.M., and Reimnitz, E., eds. PP. $18.5-212$.

Barnes, P.W. and Rearic, D.M., 1985, Rates of Sediment Disruption by Sea Ice as Determined from Characteristics of Dated Ice Gouges Created since 1975 on the Inner Shelf of the Beaufort Sea. Alaska: U.S. Geologic Survey Open-File Report 85-463, 35pp.

Barnes, P.W. and Reimnitz, E., 1972, River Overflow onto the sea ice off the northern coast of Alaska, spring 1972: Transactions, American Geophysical Union, 53: 1020 .

Barnes, P.W. and Reimnitz, E.= 1973a, New Insights into the influence of ice on the coastal marine environment of the Beaufort Sea, Alaska. Symposium on Significant Results Obtained from the Earth Resources Technology Satellite, Volume 1, Technical Presentations, Section A. Paper No. M7, PP. 1307-1314.

Barnes, P.W. and Reimnitz, E., 1973b, The shore fast ice cover and its influence on the currents and sediments along the coast of northern Alaska: Transactions, American Geophysical Union 54:1108.

Barnes, P.W., Reimnitz, E., Gustafson, C.W. and Larsen, B.R., 1973, U.S.G.S. marine studies in the Beaufort Sea off northern Alaska= 1970-1972: U.S. Geologic Survey Open-File Report 561, $11 \mathrm{pp}$.

Barnes, P.W., and Reimnitz, E., 1974, Sedimentary Processes on Arctic Shelves off the northern Coast of Alaska. in: Reed. J.C., and Sater, J.E.. eds. Beaufort Sea Coast and Shelf. Pp. 439-476.

Barnes, P.W., Reimnitz, E., Toimil, L., Maurer, D., and McDowell, D., 1979, Core Descriptions and Preliminary Observations of Vibracores From The Alaskan Beaufort Sea Shelf: U.S. Geologic Survey Open File Report 79-351 17pp.

Billings, M.P., 1972, Structural Geology. Prentice-Hall Inc.: Englewood Cliffs, New Jersey. PP. 35-94.

Black, R.F. 1964, Gubick formation of Quaternary age in northern Alaska. U.S. Geological survey Professional paper 302-c 57-91pp. 
Carsola. A.J. 1954a, Microrelief on aretic sea floor: Bulletin of American Association of Petroleum Geologists, 38: 1587-1601.

Carter, L.D., 1983b, Cenozoic glacial and glaciomarine deposits of the central North Slope, Alaska, in Thorson, R.M., and Hamilton, T.D., eds.., Glaciation in Alaska. Extended Abstracts from a workshop: Alaska Quaternary Center, University of Alaska Museum Occasional Paper No. 2, pp. 17-21.

Carter, L.D., Brigham-Grette, J., and Hopkins, D.M., 1986, Late Cenozoic Marine Transgressions of the Alaskan Arctic Coastal Plain. in: J.A. Heginbottom and J.S. Vincent eds.. Correlation of Quaternary Deposits and Events around the margin of the Beaufort Sea: Contributions from a joint Canadian-U.S. workshop 1984, Canadian Geologic Survey open file report $12-37 \mathrm{pp}=21-26$.

Clayton, L., Laird, W.M., Klassen, R.W., and Kupsch, W.0., 1965, Intersecting Minor Lineations on the Lake Agassiz Plain: Journal of Geology, $v .73$, p. $6.52-6.56$.

Clayton, L., Moran, S.R., and Bluemle, J.P., 1980, Explanatory Text to Accompany The Geologic Map of North Dakota: Report of Investigation No. 69 North Dakota Geologic Survey, $21 \mathrm{pp}$.

Colton, R.B., 1958, Note on the Intersecting Minor Ridges in the Lake Agassiz Basin, North Dakota: North Dakota Geological Survey Miscellaneous Series 10. Pp. 74-77.

Craig, J.D., Sherwood, K.W., and Johnson, P.P., 1985, Geologic Report For The Beaufort Sea Planning Area, Alaska: Regional Geology, Petroleum Geology, Environmental Geology: OCS Report MMS 85-0111, 192pp.

Craig, J.D., and Thrasher, G.F., 1982, Environmental Geology of Harrison Bay Northern Alaska: U. S. Geologic Survey Open Fil e Report 82-35, 25pp.

Dilion, W.P., and Oldale, R.N., 1978, Late Quaternary Sea Level Curve: Reinterpretation based on glaciotectonic influence: Geology, v. 6. pp. 56-60.

Dinter, D.A., 1982, Holocene Marine Sediments on the Middle and Outer Continental Shelf of the Beaufort Sea North of Alaska: Miscellaneous Investigation Series Map I-1182-B. 
Dredge, L.A., 1981, Relict Ice-Scour Marks and Late Phases of Lake Agassiz in Northernmost Manitoba: Canadian

Journal of Earth Science, V. 19 pp. 1079-1087.

Emery, K.0., 1949, "Topography and Sediments of the Artic Basin", Jour. Geol., V. 57, No. 5., pp. 512-521.

Eyles, N., and Clark, B.M., 1986, Significance of Hummocky and Swaley Cross-stratification in Late Pleistocene Lacustrine Sediments of the Ontario Basin, Canada: Geology, $v$. 14, pp. $679-682$.

Fenton, M.M., Moran, S.R., Teller, J.T., and clayton, L., 1983, Quaternary Stratigraphy and History in the Southern Part of the Lake Agassiz Basin: in Glacial Lake Agassiz: Teller, J.T., and Clayton, L., eds. Geological Association of Canada Special Paper 2t, pp. 49-74.

Gross, M.G., 1982, Oceanography: A View of the Earth. Prentice-Hall Inc. Englewood Cliffs, New Jersey, Pp. 140-172.

Horberg, L., 1951, Intersecting Minor Ridges and Periglacial Features in the Lake Agassiz Basin, North Dakota: Jour. Geology, $v .59$, no. 1 , pp. 1-18.

Kempema, E.M., 1983, Ice Gouge Infilling and Shallow Shelf Deposits in Eastern Harrison Bay, Beaufort Sea. Alaska in National Oceanic and Atmospheric Administration, Boulder, Co. Environmental Assessment of the Alaskan Continental Shelf:

Principal Investigators Reports. Year Ending March, 1983.

Kovacs, A. 1972, Ice scoring marks floor of the arctic shelf. Oil and Gas Journal (October 23), pp.92-106.

Kovacs, A. and Mellor, M., 1974, Sea Ice Morphology and Ice as a Geologic Agent in the southern Beaufort Sea: in. Reed, J.C., and Sater, J.E., eds., The Coast and Shelf of the Beaufort Sea. Arctic Institute of North America, PP. 113-163.

Mollard: J.D., 1983, The Origin of Reticulate and Orbicular Patterns On The Floor of the Lake Agassiz Basin: in Glacial Lake Agassiz: Teller, J.T., and Clayton, L., eds. Geological Association of Canada Special Paper 26. pP. 355-374.

Naidu, A.S., 1974, Sedimentation in the Beaufort Sea: a synthesis. In Marine Geology and Oceanography of the Arctic, Y. Herman (Ed.), Springer-Verlag, New York.

Naidu, A.S., Burrel, D.C., and Hood, D.W., 1971, 
Clay Mineral Composition and Geologic Significance of some Beaufort Sea Sediments: Jour. of Sed. Pet., v. 41 pp. $691-694$.

Naidu, A.S., and Mowatt, T.C., 1974, Aspects of Size Distributions Mineralogy, and Geochemistry of Detail and Adjacent Shallow Marine Sediments, north artic Alaska. U.S. Coast Guard, Oceanographic Report Series.

Naidu. A.S. and Sharma, G.D. 1972, Texture, Mineralogy and Chemistry of Arctic Ocean sediments. University of Alaska, Institute of Marine Science, Report No. R72-12, 31pp. in: U.S. Coast Gaurd, Oceanographic Report Series.

Payne, T.G. and others. 1951, Geology of the arctic slope of Alaska. U.S. Geological Survey 0 il and Gas Investigations Map 0.M. 126.

Pelletier, B.R. and Shearer, J.M. 1972. Sea bottom scouring in the Beaufort Sea of the Arctic Ocean. In Marine Geology and Geophysics, proceedings of 24 th International Geological Congress, sect.8.pp.251-61.

Reading, H.G.) 1986, Sedimentary Environments and Facies: Second Edition: Blackwell Scientific Publications, Palo Alto, Ca.

Reimnitz, E. and Barnes, P-w. 1974, Sea ice as a geological agent on the Beaufort Sea Shelf of Alaska. in: Reed, J.C., and Sater, J.E., eds. Beaufort Sea Coast and Shelf. Pp. 301-353.

Reimnitz, E. Barnes, P.W. and Alpha, T.R. 1973, Bottom features and processes related to drifting ice on the arctic shelf, Alaska. U.S. Geological Survey Miscellaneous Field Studies Map, MF-532.

Reimnitz: E. Barnes, P.W., Forgatsch, T.C. and Rodiek, C.A. 1972, Influence of grounding ice on the aretic shelf, Alaska. Marine Geology, 13:323-34.

Feimnitz, E. and Bruder, K.F. 1972, River discharge into an ice-covered ocean and related sediment dispersal, Beaufort Sea, coast of Alaska. Geological society of America Bulletin, 83:8t1-t6.

Reimnitz, E., Rodeick, C.A. and Wolf, S.C. 1974, Strudel scours: a unique arctic marine phenomenon. Journal of Sedimentary Petrology.

Reimnitz, E., Toilmil, L.J., and Barnes, P.W., 1978, Arctic Continental Shelf Morphology Related to Sea Ice Zonation, Beaufort Sea, Alaska. Marine Geology 
$\checkmark=28, P P=179-210$

Reimnitz, E., Wolf, S.C. and Rodeick, C.A. 1972, Preliminary interpretation of seismic profiles in the Prudhoe Bay area, Beaufort Sea. Alaska. U.S. Geological Survey Open File Report 548, 11 pp.

Reimnitz, E., Graves, S.M., and Barnes, P.W., in press, Beaufort Sea Coastal Erosion, Sediment Flux, Shoreline Evolution, and The Erosional Shelf Profile. $28 \mathrm{pp}$.

Reineck, H.E., and Singh, I.B., 1980, Depositional Sedimentary Environments: Springer-Verlag. New York, N.Y.

Rex: R.W., 1955. Microrelief produced by sea ice grounding in the Chukchi Sea near Barrow, Alaska. Arctic, 8:177-86.

Stearn, C.W., Carroll, R.L., and Clark, T.H., 1979, Geological Evolution of North America: Third Edition Wiley and Sons, Inc, New York, N.Y..

Tarr, R.S., 1897, The Artic Sea Ice as a Geological Agent. American Journal of Science, V. 3. pp. 223-229.

Tucker, M.E., 1981, Sedimentary Petrology An Introduction: Blackwell Scientific Publications, Halsted Press, New York, N.Y..

Walker, H.J., 1973, The Colville River and Beaufort Sea: Some Interactions: in The Beaufort Sea coast and Shelf: Reed, J.C., and Sater, J.E., eds. PP. 513-541.

Walker, H.J., 197t, Depositional Environments in the Colville River Delta: in Symposium Proceedings: Recent and Ancient Sedimentary Environments in Alaska, Miller, T.P., ed. Alaska Geologic Society PP. C1-C22.

Yorath, C.J., Shearer, J., and Havard, C.J., 1970, Seismic and Sediment Studies in the Beaufort Sea: Geological Survey of Canada Paper 71-1, Part $A$, PP. 242-244. 